\title{
VIOLÊNCIA DOMÉSTICA CONTRA A MULHER E LESÕES CORPORAIS: ASPECTOS MÉDICO-LEGAIS \\ DISSERTAÇÃO DE MESTRADO
}

ORIENTADOR: PROF ${ }^{\mathrm{a}}$. DR ${ }^{\mathrm{a}}$. IRENE BATISTA MUAKAD

FACULDADE DE DIREITO DA USP

SÃo PAULO 


\title{
VIOLÊNCIA DOMÉSTICA CONTRA A MULHER E LESÕES CORPORAIS: ASPECTOS MÉDICO-LEGAIS
}

\author{
Dissertação apresentada à Banca \\ Examinadora da Faculdade de Direito \\ da Universidade de São Paulo, como \\ exigência parcial para a obtenção do \\ título de Mestre em Direito, sob \\ orientação da Prof ${ }^{\mathrm{a}}$. Dr ${ }^{\mathrm{a}}$. Irene Batista \\ Muakad
}

FACULDADE DE DIREITO DA USP

SÃO PAULO 


\section{FICHA CATALOGRÁFICA}

Silva, Leonardo Henriques da.

Violência doméstica contra a mulher e lesões corporais: aspectos médico-legais / Leonardo Henriques da Silva - São Paulo : L. H. da Silva, 2012.

$115 \mathrm{f}$.

Dissertação (mestrado) - Faculdade de Direito da USP, 2012.

Orientador: Prof ${ }^{\mathrm{a}}$. Irene Batista Muakad

Bibliografia.

Notas de rodapé.

1. Medicina legal. 2. Violência doméstica contra a mulher 3. Lesões corporais 
Banca Examinadora

Prof $^{\mathrm{a}}$. Dr ${ }^{\mathrm{a}}$. Irene Batista Muakad - Orientadora

Prof. Dr.

Prof. Dr. 
Para minha esposa Iraci, cujo amor sincero e inesgotável é o que me sustenta em todos os momentos de minha existência 


\section{AGRADECIMENTOS}

Aos saudosos Professores Doutores Sérgio Marcos de Moraes Pitombo (in memoriam) e Marcelo Fortes Barbosa (in memoriam), da Faculdade de Direito da Universidade de São Paulo, cujos ensinamentos me despertaram a paixão pelas Ciências Criminais e sem os quais este trabalho não teria sido possível.

À querida Professora Doutora Irene Batista Muakad, do Departamento de Direito Penal, Medicina Forense e Criminologia da Faculdade de Direito da Universidade de São Paulo, pela oportunidade de prosseguir os estudos e pela paciência e compreensão durante minha orientação.

À Professora Doutora Eunice Aparecida de Jesus Prudente, do Departamento de Direito do Estado, e à Professora Doutora Helena Regina Lobo da Costa, do Departamento de Direito Penal, Medicina Forense e Criminologia, ambas da Faculdade de Direito da Universidade de São Paulo, pelas judiciosas observações e correções feitas durante o exame de qualificação.

Aos amigos da Faculdade de Direito da Universidade de São Paulo, em especial aos Mestres Luiz Malcolm Mano de Mello Filho, Daniel Morimoto e Nelson Lacava Filho, pelo apoio incondicional que é característico das grandes amizades.

À minha família, fonte de alegria nas horas felizes e porto seguro nos momentos difíceis, em especial meus pais Jorge e Maria Goretti, minha irmã Deborah Carolina e meus avós Leonarda e Mario (in memoriam). 


\section{RESUMO}

Silva, LeONARdo HenRIQUeS DA. Violência doméstica contra a mulher e lesões corporais: aspectos médico-legais. São Paulo, 2012. 115 f. Dissertação (Mestrado) Faculdade de Direito, Universidade de São Paulo, São Paulo, 2012.

O presente trabalho tem por finalidade apresentar algumas contribuições da Medicina Legal para a compreensão da violência doméstica contra a mulher. Para tanto, o trabalho parte de uma visão geral sobre a violência como fenômeno social para se chegar à ideia de violência de gênero, na qual a violência doméstica contra a mulher se encontra inserida. Após, são apresentados alguns documentos internacionais sobre violência contra a mulher para se chegar ao processo de formação da Lei $n^{\circ}$ 11.340/06. As inovações da Lei $n^{\circ} 11.340 / 06$ quanto ao crime de lesão corporal são apresentadas a seguir, culminando com a apresentação de tópicos de relevância médico-legal pertinentes à questão da violência doméstica contra a mulher.

Palavras-chave: Violência; violência de gênero; violência doméstica contra a mulher; lesões corporais; medicina legal. 


\begin{abstract}
Silva, LeOnARdo HenriQues DA. Domestic violence against women and injuries: forensic aspects. Sao Paulo, 2012. 115 f. Dissertation (Mestrado) - Faculty of Law, University of Sao Paulo, Sao Paulo, 2012.

The present work aims to present some contributions of Forensic Medicine to understanding domestic violence against women. To this end, the work presents an overview of violence as a social phenomenon to arrive at the idea of gender violence, in which domestic violence against women is inserted. In the following, some international documents on violence against women are presented to reach at Lei $\mathrm{n}^{\mathbf{o}}$ $11.340 / 06$ 's formation process. The innovations of Lei $n^{0} 11.340 / 06$ regarding the crime of personal physical injury are presented below, culminating with the presentation of relevant topics pertaining to the medical-legal issue of domestic violence against women.
\end{abstract}

Key words: Violence, gender violence, domestic violence against women; personal physical injuries; forensic medicine. 


\author{
ABREVIATURAS E SIGLAS \\ CIDH - Corte Interamericana de Direitos Humanos \\ CF/88 - Constituição Federal de 1988 \\ $\mathrm{CP}$ - Código Penal \\ CPP - Código de Processo Penal \\ DEAM - Delegacia Especializada de Atendimento à Mulher \\ JECRIM - Juizado Especial Criminal \\ JVDFCM - Juizado de Violência Doméstica e Familiar contra a Mulher \\ OEA - Organização dos Estados Americanos \\ OMS - Organização Mundial de Saúde \\ ONU - Organização das Nações Unidas \\ STJ - Superior Tribunal de Justiça \\ TJMG - Tribunal de Justiça de Minas Gerais \\ TJSC - Tribunal de Justiça de Santa Catarina
}


RESUMO

ABSTRACT

ABREVIATURAS E SIGLAS

INTRODUÇÃO ..................................................................................... 13

1. VIOLÊNCIA COMO FENÔMENO POLISSÊMICO.................... 15

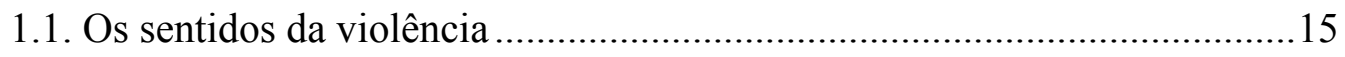

\section{VIOLÊNCIA CONTRA A MULHER EM CONTEXTO} DOMÉSTICO ......................................................................................... 20

2.1. Relações de gênero e violência .............................................................20

2.2. Ambiente familiar: locus privilegiado da violência contra a mulher? .......29

2.3. Violência doméstica contra a mulher: delimitação conceitual ...................35

\section{VIOLÊNCIA DOMÉSTICA CONTRA A MULHER: A} ABORDAGEM JURÍDICA ............................................................. 41

3.1. A violência contra a mulher como ofensa aos Direitos Humanos

3.2. Documentos internacionais sobre violência contra a mulher

3.2.1. Convenção sobre a Eliminação de Todas as Formas de

Discriminação contra a Mulher (1979)

\subsubsection{Convenção Interamericana para Prevenir, Punir e Erradicar a} Violência contra a Mulher (1994) 
4.1. Panorama institucional 54

4.1.1. As Delegacias Especializadas de Atendimento à Mulher... 55

4.1.2. Os Juizados de Violência Doméstica e Familiar contra a Mulher .58

4.1.3. Outros órgãos governamentais e não-governamentais 64

\section{A TUTELA PENAL DA INTEGRIDADE FÍSICA NO DIREITO

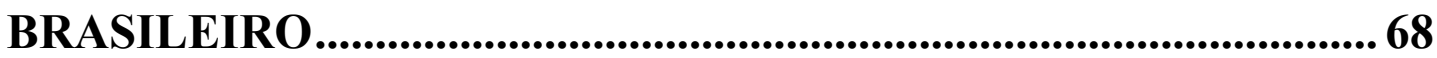

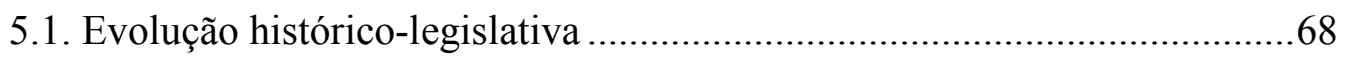

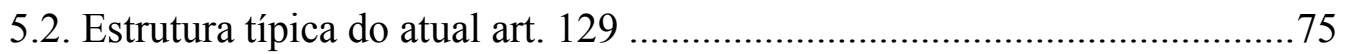

\section{VIOLÊNCIA DOMÉSTICA CONTRA A MULHER E TUTELA}

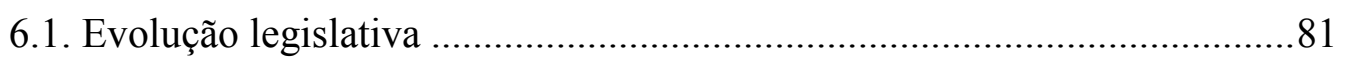

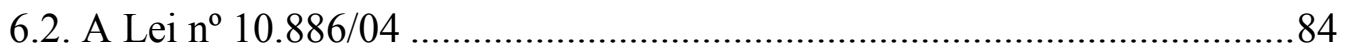

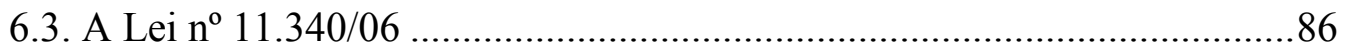

6.4. Há um crime de violência doméstica contra a mulher?.

\section{A MEDICINA LEGAL E SUAS CONTRIBUIÇÕES PARA A COMPREENSÃO DO FENÔMENO................................................91}

7.1. Considerações preliminares

7.2. A mensuração dos casos de lesão corporal decorrente de violência doméstica contra a mulher.

7.3. O âmbito de proteção da Lei 11.340/06 e a identificação médico-legal do sexo

7.4. As formas de violência contra a mulher e sua apuração médico-legal ....112 


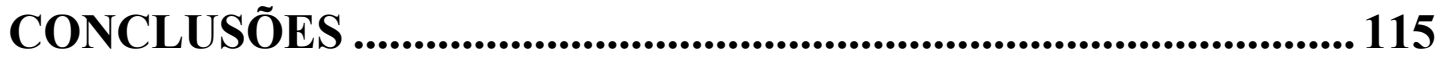

REFERÊNCIAS BIBLIOGRÁFICAS.........................................118 


\section{INTRODUÇÃO}

A violência praticada contra a mulher no contexto doméstico, por parte do marido ou parceiro, apresenta números significativos no Brasil e no mundo. A Organização Mundial de Saúde (OMS) estimou, a partir de 48 estudos de base populacional conduzidos em todo o mundo, que o índice de mulheres que já foram agredidas pelo seu parceiro chega a oscila entre $10 \%$ e $69 \%$ da população feminina ${ }^{1}$.

As consequências da violência doméstica para a pessoa agredida são severas e abrangem diversas dimensões, desde ocorrência de fraturas, luxações e hematomas até impactos psicológicos e comportamentais, como depressão, ansiedade, dependência química e farmacológica, ou, em casos mais severos, desequilíbrios que levam a suicídios.

A literatura existente no Brasil sobre o tema é indicativa do interesse que o tema desperta. A maioria desses estudos, porém, dão ênfase a dois aspectos bem delimitados: de um lado, privilegia-se a análise da violência doméstica contra a mulher apenas sob o prisma da Saúde Pública, enfocando as relações entre os gêneros e buscando estabelecer novos parâmetros nas políticas públicas sobre a saúde da mulher; de outro, privilegia-se a análise apenas sob o prisma jurídico, em particular o jurídico-penal, enfocando a regulamentação legal do fenômeno e as conseqüências das práticas agressivas no âmbito penal.

No nosso sentir um fenômeno de tal modo disseminado pela sociedade apresenta nítida relevância médico-legal, uma vez que a violência nesses casos se traduz, na esmagadora maioria dos casos, em agressões e ofensas diversas à integridade física e mental da mulher.

Assim, uma abordagem médico-legal da violência doméstica contra a mulher se mostra desejável para a melhor compreensão do fenômeno, inclusive para contribuir às demais abordagens.

\footnotetext{
1 In World Report on Violence and Health. Genebra, OMS, 2002, p. 89. Disponível em: $<$ http://whqlibdoc.who.int/hq/2002/9241545615.pdf $>$ (em inglês). Acesso em 10.12.2011.
} 
Por razões metodológicas a pesquisa foi dividida em três partes. Na primeira parte a intenção foi delimitar conceitualmente a violência doméstica contra a mulher a partir do fenômeno da violência em sua forma mais ampla, considerado como elemento - e desafio - da vida em sociedade. Para tanto se procedeu a uma revisão de estudos existentes sobre o tema feitos com referenciais próprios das Ciências Humanas e Sociais, na tentativa de se definir em que medida essas abordagens repercutem na abordagem jurídica do tema.

Ainda na primeira parte se analisou como a preocupação sobre o tema da violência doméstica contra a mulher, inicialmente surgida no plano internacional, se traduziu na edição de legislação específica sobre o assunto no ordenamento jurídico brasileiro.

$\mathrm{Na}$ segunda parte da pesquisa foi traçado breve panorama sobre o crime de lesões corporais, revisando a evolução legislativa do referido delito até a edição da Lei $\mathrm{n}^{\circ}$ 11.340/06 e definindo qual o regime específico do crime em tela quando cometido contra a mulher em contexto de violência doméstica.

$\mathrm{Na}$ terceira parte foram apresentadas as contribuições que a Medicina Legal, a nosso ver, pode oferecer à compreensão e enfrentamento da violência doméstica contra a mulher.

Por fim, encerramos o trabalho com a apresentação de nossas conclusões a partir do quanto pesquisado nas três partes do estudo e da bibliografia consultada. 


\section{VIOLÊNCIA COMO FENÔMENO POLISSÊMICO}

\subsection{Os sentidos da violência}

Um ponto de partida válido para a compreensão da violência doméstica contra a mulher está na delimitação de um conceito capaz de descrever o fenômeno com a maior precisão possível. Para tanto, necessário se faz definir o que se entende por violência em sentido lato para, a partir daí, destacar os aspectos que sejam de maior relevância para o estudo ora desenvolvido.

Uma primeira dificuldade reside no fato de inexistir um conceito único, inequívoco, do que se entende por violência. A palavra violência é polissêmica - isto é, abrange sentidos diversos e pode ser utilizada para descrever contextos diversos - e essa polissemia repercute no seu uso reiterado, em especial pelos meios de comunicação.

A palavra violência é usada para descrever desde as formas mais cruéis de tortura e homicídio até aspectos mais recorrentes da vida cotidiana, tais como certas relações sociais, econômicas e culturais. Essa pluralidade de sentidos pode constituir um problema na medida em que estudiosos diversos, de diversas áreas do conhecimento, podem empregar o mesmo termo com sentidos próprios, dificultando o diálogo entre suas considerações acerca da violência.

Jean-Marie Domenach, citado por Ana Flávia Pires Lucas d'Oliveira ${ }^{2}$, chama a atenção para o fato de a violência só recentemente ter se tornado um problema central para a humanidade, apesar de estar presente em toda a história. Este fato é associado à modernidade, que almeja a possibilidade de cidadania, liberdade e felicidade para todos.

A partir deste momento, segundo o referido autor, ações antes diversas e que eram percebidas como inevitáveis na ordem do mundo, e mesmo desejáveis, passam a ser nomeadas em conjunto como violência e combatidas. Nesse

\footnotetext{
${ }^{2}$ In Violência de gênero, necessidades de saúde e uso de serviços em atenção primária. Tese de doutorado. Faculdade de Medicina da USP, 2000, p. 22.
} 
sentido uma definição de violência passa pela ideia de que esta é sempre uma manifestação da vontade humana, diferente das catástrofes naturais e da ação animal predadora, pois tem relação com a liberdade.

A violência, como forma de relação entre dois sujeitos, consistiria então na extensão da liberdade de um no sentido de forçar à liberdade do outro. O autor questiona, ainda, se todos os diversos tipos de violência poderiam ser moralmente condenáveis a princípio, e conclui-se que a violência é indissociável da experiência humana e que, em sua análise, devem ser necessariamente considerados os meios, as circunstâncias e os fins: para Domenach, condenar todas as violências é absurdo e hipócrita, enquanto fazer o elogio da violência, por outro lado, é criminoso.

As ideias de Estado e de violência em muito se relacionam, na medida em que o Estado é visto pela Ciência Política e pela Sociologia como instituição cuja existência depende, em grande medida, do uso da violência.

Nesse sentido, Thomas Hobbes sustenta que é com surgimento institucional do Estado que a humanidade pôs fim aquele modelo de Estado a que convencionou chamar de estado de natureza, qual seja aquele em que o homem é o próprio lobo do homem:

"Para todo o homem, outro homem é um concorrente, como ele é ávido por poder sob todas as suas formas. (...) Concorrência, desconfiança recíproca, avidez de glória ou de fama têm por resultado a guerra perpétua de cada um contra cada um, de todos contra todos. Guerra, isto é, não só o fato atual de bater-se mas a vontade averiguada de bater-se: enquanto existe tal vontade, há guerra e não paz, e o homem é um lobo para o homem:' homo homini lupus ",.".

Com o Leviatã, obra de 1615, Hobbes explica a passagem do homem natural para o homem artificial, ao Estado-Leviatã. Buscando abandonar esta

\footnotetext{
${ }^{3}$ In O Leviatã. São Paulo: Martins Fontes, 1992, p 69/70.
} 
condição de absoluta insegurança é que os homens resolveram conceder uma parcela de sua liberdade ao Estado, a fim de que esse lhes garantisse paz e segurança. Estava instituído assim, o que Rousseau mais tarde chamou de "Contrato Social", firmado entre os cidadãos, e sob o qual foi edificado o Estado.

Por esse contrato, os indivíduos abandonariam o estado de natureza na qual viviam e cujo limite era não mais do que a força de uns sobre os outros, o que significa dizer que os mais fortes submetiam os mais fracos aos seus desígnios para viver sob a tutela do Estado Institucionalizado. A partir de então, estabeleceram-se novos limites aos quais cabia ao Estado definir e exercer. "A condição natural de liberdade absoluta foi então substituída por um estado social de limites, direitos e obrigações que deveriam ser respeitados por todos os homens". 4

Ao Estado coube então, a tarefa de organizar os indivíduos em sociedade, definindo regras de convivência, e o que é mais significativo, estabelecendo sanções àqueles cujo comportamento resultasse em violação do contrato. É exatamente este poder de coerção, que impõe aos homens a sua sujeição ao Estado e às regras por ele estabelecidas.

Não se trata, entretanto, de uma imposição arbitrária, mas consentida pelos próprios contratantes, visto que a troca de liberdade foi motivada, sobretudo, pela garantia de paz e segurança.

Neste sentido, afirma Sônia T. Felipe:

"Sem a força da espada, a lei seria para o autor (Hobbes) mera declaração de princípios, sem qualquer possibilidade de efetivação prática dos objetivos por ela propostos. O peso da espada garante, nesta perspectiva, a concreção dos fins do Estado, ao coibir a agressividade inerente aos seres humanos. Dessa forma, se o objetivo primeiro do Estado é manter a sociabilidade segura, os meios utilizados para este fim, desde que ele seja realmente obtido,

\footnotetext{
${ }^{4}$ In A Violência das Mortes por Decreto - Um ensaio sobre Direito e Psicanálise a Três Estudos de Filmes à luz do Contratualismo. Florianópolis: Gráfica UFSC, 1996, p. 56.
} 
são a priori, legítimos, na medida em que um bem maior - a paz e a segurança - que afeta a todos indistintamente, deve ser resguardado".

Evidentemente que a definição contemporânea de Estado, apresenta profundas alterações em face daquela apresentada por Hobbes, até mesmo porque se trata de um modelo construído sob o regime absolutista medievo.

Modernamente, a concepção de Estado de Direito não pode estar dissociada da democracia. A própria Constituição Federal de 1988 determina no art. $1^{\circ}$ que a República Federativa do Brasil constitui-se em um Estado Democrático de Direito, tendo por base o princípio da legalidade, o que significa dizer que "sujeita-se ao império da lei, mas da lei que realize o princípio da igualdade e da justiça não pela sua generalidade, mas pela busca da igualização das condições socialmente desiguais." 5

Em que pese toda a evolução histórica do Estado, desse não se pode também afastar a ideia de coerção. Somente o Estado detém o monopólio da coerção legítima, que deve ser utilizada exclusivamente para a garantia da segurança dos cidadãos, tendo como limite a própria lei. Max Weber afirma que "só um instrumento consente definir sociologicamente o Estado Moderno, bem como toda a associação política: a força".

O referido autor, ao apresentar seu conceito de Estado, define-o como sendo "aquela comunidade humana que, dentro de um determinado território reivindica para si, de maneira bem sucedida, o monopólio da violência física legítima". 6

Segundo Weber é a institucionalização da violência que sustenta o próprio Estado e que lhe garante legitimidade para impor normas. Somente

\footnotetext{
${ }^{5}$ SILVA, José Afonso da. Curso de Direito Constitucional Positivo. 12a ed.. São Paulo: Malheiros, 1996, p. 127.

${ }^{6}$ Apud BONAVIDES, Paulo. Ciência Política. Rio de Janeiro: Forense, 1993, p. 101.
} 
o Estado, no exercício de sua função precípua de promover o bem comum, garantindo aos indivíduos paz e segurança, é que pode estabelecer e aplicar sanções, valendo-se para tanto, do legítimo poder de coerção de que dispõe. Weber acaba por reconhecer "o Estado como a derradeira fonte de toda a legitimidade, tocante à utilização da força física ou material". 7

O que se pretende evidenciar por certo é o exclusivo poder de coerção de que o Estado dispõe. E é especialmente através das leis e dos aparelhos repressivos que ele exerce este Poder institucionalmente outorgado. Destarte, é função do Estado a repressão às situações potencialmente ofensivas aos cidadãos.

Assim, temos que desde a formação da principal estrutura de organização da sociedade ocidental - o Estado - a violência se faz presente como elemento da vida humana. Resta verificar como ela se manifesta em um dos contextos mais elementares de convivência humana: a relação entre homens e mulheres.

${ }^{7}$ Op. cit., p. 55 . 


\section{VIOLÊNCIA CONTRA A MULHER EM CONTEXTO DOMÉSTICO}

\subsection{Relações de gênero e violência}

Uma vez que a violência é um elemento da vida em sociedade, na medida em que esta é pautada por relações de poder entre os indivíduos que a integram e essas relações envolvem, em maior ou menor escala, o uso de força com o fim de submeter a vontade de um à vontade de outrem, parece adequado falar que diferentes formas de relação entre indivíduos são acompanhadas de diferentes formas de violência.

Um dos principais contextos de relacionamento entre indivíduos na sociedade é aquele no qual a distinção entre homens e mulheres se faz determinante dos limites desse relacionamento, em especial pela assimetria de poder entre homens e mulheres, assimetria essa que via de regra se dá em favor daqueles em detrimento destas últimas.

A essas relações pautadas pela diferença e pela assimetria de poder entre homens e mulheres se dá o nome de relações de gênero.

A ideia de gênero, surgida na Sociologia, se vê incorporada pelo Direito na medida em que as diferenças entre homens e mulheres são vistas como construções sociais, e como tais são passíveis de intervenção por meio de normas jurídicas. Nesse sentido, define Carmen Hein de Campos:

"Como conceito sociológico, é utilizado como uma categoria analítica que reconhece que as diferenças entre homens e mulheres são construidas socialmente e se fundam em relações de poder. Por intermédio das relações de gênero, papéis sociais 
diferenciados são atribuidos ao feminino e ao masculino com sobrevaloração do sexo masculino. ${ }^{8,}$

Em igual sentido, temos a definição de gênero utilizada pela Organização das Nações Unidas para a Educação, Ciência e a Cultura - UNESCO 9 :

"Gênero se refere às relações e diferenças sociais entre homens e mulheres que são aprendidas, variam amplamente nas sociedades e diferentes culturas, e mudam com o passar do tempo. O termo gênero não substitui o termo sexo, que se refere exclusivamente às diferenças biológicas entre homens e mulheres. Por exemplo, dados estatísticos são apresentados por sexo. O termo gênero é usado para analisar as funções, responsabilidades, obrigações e necessidades de homens e mulheres nas diferentes áreas $e$ contextos sociais".

Uma vez que as diferenças sociais em razão do gênero se traduzem em desigualdades econômicas e políticas, colocando as mulheres em posição inferior à dos homens nas mais diversas esferas da vida social, é comum que a assimetria de poder em favor do homem se exteriorize por meio de práticas violentas contra a mulher.

Surge, aqui, o conceito de violência de gênero, a qual se traduz por uma relação de dominação do homem e de submissão da mulher pautada pelos papéis históricos impostos aos sexos e reforçados pela sociedade, os quais induzem relações violentas entre os sexos.

\footnotetext{
${ }^{8}$ CAMPOS, Carmen Hein de. "O direito a uma vida sem violência". In: LIMA, Fausto Rodrigues de; SANTOS, Claudiene (Coords.). Violência doméstica: vulnerabilidade e desafios na intervenção criminal e multidisciplinar. Rio de Janeiro: Lúmen Juris, 2009, p. 23.

${ }^{9}$ UNESCO. De Mãos Dadas com a Mulher: a UNESCO como agente promotor da igualdade entre gêneros. Brasília: UNESCO, 2002, p. 71. Disponível em $<$ http://unesdoc.unesco.org/images/0012/001271/127141 por.pdf $>$. Acesso em 19.06.2011.
} 
O conceito de violência de gênero é de natureza ampla, no qual estão inseridas como vítimas em sentido lato tanto mulheres quanto crianças e adolescentes de ambos os sexos.

Essa opção metodológica se justifica, segundo Heleieth Saffioti $^{10}$, pelo fato de no exercício da função patriarcal os homens serem detentores do poder de determinar a conduta das categorias sociais nomeadas de acordo com a sua vontade, recebendo autorização ou, pelo menos, tolerância da sociedade para punir o que se lhes apresenta como desvio. E essa tolerância permite que sua capacidade de mando seja auxiliada pelo emprego de violência em suas mais diversas variações.

Nesse sentido, prossegue a referida autora expondo de que modo o exercício da violência de gênero transcende, em diversas situações, os limites da figura masculina:

Com efeito, a ideologia de gênero é insuficiente para garantir a obediencia das vitimas potenciais aos ditames do patriarca, tendo este necessidade de fazer uso da violência. Nada impede, embora seja inusitado, que uma mulher pratique violência fisica contra seu marido/companheiro/namorado. As mulheres como categoria social não têm, contudo, um projeto de dominação-exploração dos homens. E isto faz uma gigantesca diferença. Com relação a crianças e a adolescentes, também as mulheres podem desempenhar, por delegação, a função patriarcal. Efetivamente, isto ocorre com freqüencia. No processo de edipianização das gerações mais jovens, mães, professoras, babás, para mencionar apenas alguns destes agentes, exercem a função do patriarca. No estupendo filme dirigido por Zhang Yimou - Lanternas vermelhas - fica bem claro que a figura do patriarca pode ser encarnada por qualquer cidadão. Com efeito, o patriarca do filme, com quatro esposas, nunca é mostrado de forma nítida. Nenhum espectador vê seu rosto, pois ele é sempre filmado na penumbra, de perfil e de costas. Yimou, que já se dedicou a analisar o

10 "Contribuições feministas para o estudo da violência de gênero". Cadernos Pagu, Campinas, n. 16, 2001, p. 115. 
patriarcado em outros produtos de sua filmografia, apreendeu corretamente que o poder é atribuido à categoria social homens, podendo cada exemplar desta categoria utilizá-lo ou não, ou ainda delegá-lo. A primeira esposa, por exemplo, se distinguia das demais, na medida em que, por um lado, já não se apresentava com atrativos sexuais e, por outro, certamente em decorrência disto, tornara-se uma espécie de juiza, cabendo-lhe exigir o cumprimento das normas que, tradicionalmente, regiam aquele estado-de-coisas. Várias formas de violência de gênero são perpetradas contra as esposas sem que o agente imediato destas práticas seja, necessariamente, o patriarca. Ao contrário, este até parece afável em várias circunstâncias. A ordem patriarcal de gênero, rigorosamente, prescinde mesmo de sua presença física para funcionar. Agentes sociais subalternos, como os criados, asseguram a perfeita operação da bem azeitada máquina patriarcal. Até mesmo a eliminação fisica de quem comete uma transgressão de gênero pode ser levada a cabo na ausência do patriarca por aqueles que desempenham suas funções. Em outro filme dirigido por Yimou - Amor e sedução — pode-se assistir ao processo de construção do patriarca, cuja prática da violência se revela desde a infância. Cabe chamar a atenção para o fato de que esta violência de gênero praticada diretamente pelo patriarca ou por seus prepostos pode recair sobre outro homem. Nada impede também que uma mulher perpetre este tipo de violência contra um homem ou contra outra mulher. A ordem das bicadas na sociedade humana é muito complexa, uma vez que resulta de três hierarquias/ contradições - de gênero, de etnia e de classe. $O$ importante a reter consiste no fato de o patriarca, exatamente por ser todo poderoso, contar com numerosos asseclas para a implementação e a defesa diuturna da ordem de gênero garantidora de seus privilégios ${ }^{11}$.

Esse exercício da violência no contexto das relações de gênero, além dos reflexos deletérios que são gerados entre os agentes diretamente envolvidos num contexto particular, se mostra particularmente nocivo por dar

\footnotetext{
${ }^{11}$ Op. cit., p. $116 / 117$
} 
margem à construção do que Pierre Bourdieu chamou de dominação simbólica, por meio da qual a sujeição que inicialmente deriva do uso da violência acaba por ser vista, com o tempo, como axiologicamente neutra:

A força da ordem masculina pode ser aferida pelo fato de que ela não precisa de justificação: a visão androcêntrica se impõe como neutra e não tem necessidade de se enunciar, visando sua legitimação. A ordem social funciona como uma imensa máquina simbólica, tendendo a ratificar a dominação masculina na qual se funda: é a divisão social do trabalho, distribuição muito restrita das atividades atribuidas a cada um dos dois sexos, de seu lugar, seu momento, seus instrumentos...(... $)^{12}$

Desse modo, ainda segundo Bourdieu, aquilo que se busca alcançar com o emprego da violência se traduz em uma nova forma de violência, desta vez incorporada ao cotidiano das vítimas como um elemento normal da realidade e por elas aceito como tal:

A violência simbólica institui-se por meio da adesão que o dominado não pode deixar de conceder ao dominador (logo, à dominação), uma vez que ele não dispõe para pensá-lo ou pensar a si próprio, ou melhor, para pensar sua relação com ele, senão de instrumentos de conhecimento que ambos têm em comum e que, não sendo senão a forma incorporada da relação de dominação, mostram esta relação como natural; ou, em outros termos, que os esquemas que ele mobiliza para se perceber e se avaliar ou para perceber e avaliar o dominador são o produto da incorporação de classificações, assim naturalizadas, das quais seu ser social é o produto $^{13}$.

O cotidiano é formado pela dominação de gênero. A situação privilegiada do homem, decorrente do processo de dominação simbólica apontado por Bourdieu, aparece como algo natural nas mais diversas esferas da vida em

\footnotetext{
${ }^{12}$ BOURDIEU, Pierre. A dominação masculina. Rio de Janeiro: Bertrand Brasil, 2003, p. 16.

${ }^{13}$ Op. cit., p. 42
} 
sociedade: o salário inferior concedido à mulher por trabalho igual, regras morais severas que ditam o que convém ou não a uma "moça de família", o uso da violência sexual como estratégia de confronto em operações militares, e assim sucessivamente.

A despeito das transformações sociais ocorridas nas últimas décadas, o fato de que mulher e homem ainda (con)vivem em relações de natureza hierarquizada se mostra evidente.

As relações de gênero têm como transversal em sua dinâmica a dominação e o poder. O poder necessariamente implica numa relação de dominação, no nosso caso especifico, de homens sobre mulheres. Entretanto, pensar esta dinâmica como unilateral, ou seja, como uma barbárie masculina é incorrer no erro da vitimização.

Historicamente a mulher tem um papel dentro da família ocidental tido como muito importante: a administração do lar e a criação dos filhos. A despeito da relevância que se atribui a esse papel da mulher desde a Antiguidade cabe salientar o poder do homem sobre sua esposa, filhos, escravos e todos aqueles que residiam em sua propriedade, ainda que pessoas livres.

Nesse sentido, temos a exposição de Mario Curtis Giordani ao tratar das relações familiares na sociedade romana, as quais influenciaram - e ainda influenciam - a definição dos padrões de relacionamento na sociedade ocidental:

Na expressão paterfamilias, a palavra pater significa chefe e não pai (genitor). Com efeito, paterfamilias era aquele que possuía o poder na sociedade doméstica (potestas, dominium in domo). Desde a época das XII tábuas, pode-se distinguir os seguintes poderes integrando a autoridade do paterfamilias: a patria potestas (sobre os filhos), a manus (sobre a mulher), dominica potestas (sobre os escravos) e o mancipium (sobre pessoas livres 
alieni iuris que passaram de um paterfamilias a outro, por exemplo, pela venda) $)^{14}$.

Salienta-se que, conforme pode ser entendido, o homem considerado paterfamilias (chefe de família) na tradição romana não era necessariamente o marido, posto que a mulher, ao casar, saía de sua residência, onde morava com pais e irmãos, para morar na casa do marido, com pais e irmãos dele. Nesse caso, o paterfamilias é o sogro, uma vez que dono da casa e responsável por todos aqueles que nela residem.

$\mathrm{Na}$ formação da sociedade ocidental o poder do homem teve várias fontes, tais como o exercício da cidadania, os ganhos salariais que mantinham a economia da família, e a própria liberdade que possuía. A mulher, por sua vez, nem mesmo poderia ser considerada cidadã, uma vez que por toda a sua existência vivia às sombras de um homem

Neste sentido, afirma Eric Hobsbawm:

(...) os homens eram o sexo dominante, e as mulheres, seres humanos de segunda classe: posto que careciam totalmente de direitos de cidadania, não se podia sequer chamá-las cidadãs de segunda classe. ${ }^{15}$

A cidadania, além de somente ser exercida por homens, ainda era privilégio de algumas classes sociais, ou seja, homens de baixas rendas e poucas propriedades não a exerciam.

A inferioridade da mulher em face do homem mesmo nas classes mais baixas não a privava, contudo, de obrigações tais como o trabalho. Quanto à importância do trabalho feminino, também declara Hobsbawm:

\footnotetext{
${ }^{14}$ In História de Roma - Antiguidade Clássica II. 15a edição. Petrópolis: Editora Vozes, 2002, p. 162.

${ }^{15}$ In A era das revoluções: Europa 1789 - 1848. $15^{\text {a }}$ ed.. Rio de Janeiro: Paz e Terra, 2001, p. $282 / 283$.
} 
Os agricultores precisavam das esposas para o trabalho da fazenda, bem como para cozinhar e criar os filhos; e os mestresartesãos e pequenos lojistas necessitavam delas para conduzir seu comércio. Se existiam ocupações que reuniam homens sem mulheres, durante longo periodos - digamos as dos soldados e marinheiros -, não existiam ocupações puramente femininas (exceto talvez a prostituição e os divertimentos públicos, a ela assimilados) que não fossem, normalmente, levadas a efeito, a maior parte do tempo, dentro de uma casa; pois mesmo mulheres e homens solteiros que se empregavam como criados $e$ trabalhadores agrícolas "moravam na casa". Na medida em que o grosso das mulheres do mundo continuavam a viver desse modo, agrilhoadas pelo duplo trabalho e pela sua inferioridade em relação ao homem, pouco há que dizer sobre elas que não se dissesse igualmente nos tempos de Confúcio, de Maomé ou do Velho Testamento. Elas não estavam fora da história, mas estavam fora da história da sociedade do século XIX. ${ }^{16}$

Com o avanço da modernidade, notadamente a partir da Revolução Industrial, a situação feminina modificou-se, principalmente nas classes mais baixas, em que a necessidade das famílias de aumentar sua renda colocou cada vez mais mulheres no mercado de trabalho.

Tornou-se comum ver mulheres concorrendo com homens em busca de vagas de emprego, ainda que em condições de inferioridade, uma vez que prevalecia a visão de que as mulheres eram seres inferiores dominadas pelo sexo dominante: o masculino. Entretanto, grande número de mulheres passou a trabalhar como lojistas, comerciantes, feirantes e outras profissões afins mesmo contrariando as expectativas sociais, conforme Hobsbawm descreve:

Na época pré-industrial, as mulheres que cuidavam pessoalmente de suas propriedades ou empresas eram reconhecidas, embora incomuns. No século XIX, foram, cada vez mais, consideradas aberrações da natureza, a não ser nos niveis sociais mais baixos, onde a pobreza e o rebaixamento geral das "ordens inferiores"

\footnotetext{
${ }^{16}$ Op. cit., p. 276/277.
} 
impossibilitava considerar assim tão "desnaturadas" as mulheres que perfaziam o grande número das lojistas, das feirantes, das estalajadeiras e das donas de pensão, das pequenas comerciantes e das prestamistas. ${ }^{17}$

A industrialização do século XIX marcou ainda mais essa nova fase feminina, uma vez que disponibilizou mais vagas de empregos para homens, mulheres e crianças nas fábricas e escritórios. Aos poucos, a economia familiar passou a receber contribuição da mulher, mãe e ainda dona-de-casa, uma vez que as famílias das quais a mulher trabalhava eram de baixa renda, não sendo possível substituir o papel da mulher.

Com isso agravou-se ainda mais a situação de inferioridade da mulher, pois além de arcar com o trabalho doméstico e da criação dos filhos eralhe exigido que trabalhasse para contribuir com o sustendo da casa, muitas vezes com seus maridos, aumentando ainda mais sua dependência econômica. Refere-se Hobsbawm nesse sentido:

(...) tantas mulheres casadas que precisavam ganhar dinheiro, mas permaneciam acorrentadas à cozinha e às crianças, acabaram por fazer esses trabalhos. Pois o segundo efeito da industrialização em relação à posição feminina, e o mais importante, foi também muito mais drástico: separou a casa do local de trabalho. E, ao fazer isto, excluiu-as em larga medida da economia publicamente reconhecida - aquela em que eram pagos os salários às pessoas e agravou sua tradicional inferioridade em relação aos homens por meio da nova dependência econômica. Os camponeses, por exemplo, dificilmente existiriam como tais sem as esposas. $O$ trabalho agrícola exigia a mulher, bem como o homem. Era absurdo considerar os rendimentos da casa como ganhos por um dos sexos e não por ambos, mesmo se um deles fosse tido como dominante ${ }^{18}$.

\footnotetext{
${ }^{17}$ Op. cit., p. $281 / 282$.

${ }^{18}$ Op. cit., p. 278/279.
} 
Quando não estava trabalhando com seu marido, a mulher era considerada uma rival, uma vez que seu trabalho custava pouco aos empregadores, os homens acabavam por concorrer com elas por vagas de emprego, sujeitando-se a salários mais baixos para conseguir emprego. Diante da competição, os homens acabaram por proibir e coibir as mulheres para que não pudessem trabalhar fora de casa, resultando em maior dependências delas aos maridos.

Hobsbawm destaca a situação do trabalho feminino perante a concorrência masculina:

(...) a mulher devia receber menos, desde que não era dela que provinha a renda familiar. Uma vez que os homens, mais bem pagos, teriam seus salários reduzidos pela competição das mulheres, mal pagas, a sua estratégia lógica era a de excluir, se possivel, tal competição, compelindo ainda mais as mulheres à dependência econômica e aos empregos perenemente mal pagos ${ }^{19}$.

Verifica-se, pois, que na sociedade ocidental as relações de gênero foram construídas sob o signo de uma dupla desigualdade: as mulheres se inserem na ordem capitalista sem se dissociar das obrigações próprias da ordem familiar, por um lado, e sem receber a autonomia e os direitos civis que eram próprios do homem. Essa desigualdade acaba por se manifestar mesmo nos dias atuais, como se verá a seguir.

\subsection{Ambiente familiar: locus privilegiado da violência contra a mulher?}

Dentre os diversos contextos nos quais se desenvolvem as relações de gênero, é no ambiente doméstico-familiar em que as manifestações de

${ }^{19}$ Op. cit., p. $279 / 280$. 
violência contra a mulher ocorrem de forma privilegiada e estruturante, como observa Ana Lucia Sabadell ${ }^{20}$ :

A violência doméstica não constitui uma patologia de certos indivíduos, grupos ou classes sociais ("José é violento"; "os alcoólatras são violentos"; "os pobres são violentos"), tampouco se trata de um fenômeno aleatório. A violência doméstica, como indicam as pesquisas feministas, é um correlato da construção histórico-social das relações desiguais entre os gêneros. Constitui um meio sistematicamente empregado para controlar as mulheres mediante a intimidação e o castigo, mesmo se, no senso comum, prevalece a ideia de que a violência doméstica é algo isolado, que pode ser atribuido a patologias do homem ou do casal.

\section{(...)}

Por violência de gênero, entende-se a violência praticada contra a mulher no âmbito do processo de dominação masculina, que visa submetê-la às regras da cultura patriarcal. Por este motivo, no âmbito dos estudos feministas, é corriqueira a definição deste tipo de violência como aquela praticada contra a mulher pelo fato de pertencer ao gênero feminino. Esse conceito abrange não só a violência direta, manifesta, mas também formas de violência sutis e encobertas, compreendendo, portanto, todas as formas de pressão dirigida ao corpo e à psiquê da mulher que impedem ou limitam a sua autodeterminação.

Estamos diante de um conceito de violência que é estrutural. Designa um fenômeno ligado à constituição da cultura patriarcal que estabelece padrões de comportamento por meio de mecanismos de controle social informal e formal. O paternalismo e a ideologia da inferioridade, ao veicularem, no âmbito da cultura patriarcal, uma imagem de dependência e de impotência da mulher, favorecem, em todos os niveis da sociedade, a reprodução

${ }^{20}$ SABADELL, Ana Lucia. Perspectivas jussociológicas da violência doméstica: efetiva tutela de direitos fundamentais e/ou repressão penal. In: Revista dos Tribunais, São Paulo, v. 840, 2005, p. 439. 
da concepção da mulher como objeto, reproduzindo-se assim a violência de gênero.

Ainda segundo a mesma autora, a violência doméstica é uma forma de violência física e/ou psíquica exercida pelos homens contra as mulheres no âmbito das relações de privacidade e intimidade de cunho familiar ou de convivência amorosa, que expressa o exercício de um poder de posse, de caráter patriarcal. $\mathrm{O}$ traço distintivo deste tipo de violência é o fato de ocorrer nas (e decorrer das) relações privadas.

Essa violência, embora própria da vida privada, se mostra notavelmente perniciosa na sociedade como um todo, uma vez que essas relações de posse entre homens e mulheres acabam transcendendo a esfera familiar e pautando as relações de gênero em outros contextos, legitimando e perpetuando a dominação do homem sobre a mulher.

A violência doméstica, portanto, funcionaria como um mecanismo de controle social informal ao condicionar homens e mulheres a reproduzir comportamentos de dominação que são observados no seio da entidade familiar.

Desse modo, é possível dizer que o ambiente familiar se mostra especialmente propício ao desenvolvimento de práticas violentas contra a mulher, ainda que sem redundar necessariamente em violência física, por conta das relações de poder que são inerentes ao relacionamento familiar.

Nesse sentido, afirma Flávia Piovesan ${ }^{21}$ :

A violência contra as mulheres é uma manifestação de relações de poder historicamente desiguais entre homens e mulheres que conduziram à dominação e à discriminação contra as mulheres pelos homens e impedem o pleno avanço das mulheres. A

${ }^{21}$ PIOVESAN, Flávia. Direitos Humanos e o Direito Constitucional Internacional. São Paulo: Max Limonad, 1996, p. 113. 
Conferência das Nações Unidas sobre Direitos Humanos (Viena, 1993) reconheceu formalmente a violência contra as mulheres como uma violação aos direitos humanos. Desde então, os governos dos países-membros da ONU e as organizações da sociedade civil têm trabalhado para a eliminação desse tipo de violência, que já é reconhecido também como um grave problema de saúde pública.

Para a OMS (Organização Mundial da Saúde), as conseqüências do abuso são profundas e vão muito além da saúde e da felicidade individual e afetando o bem-estar de comunidades inteiras.

\section{Segundo Silvia Pimentel ${ }^{22}$ :}

A violência contra a mulher acontece porque em nossa sociedade muita gente ainda acha que o melhor jeito de resolver um conflito é a violência e que os homens são mais fortes e superiores às mulheres. É assim que, muitas vezes, os maridos, namorados, pais, irmãos, chefes e outros homens acham que têm o direito de impor suas vontades às mulheres. Embora muitas vezes o álcool, drogas ilegais e ciúmes sejam apontados como fatores que desencadeiam a violência contra a mulher, na raiz de tudo está a maneira como a sociedade dá mais valor ao papel masculino, o que por sua vez se reflete na forma de educar os meninos e as meninas. Enquanto os meninos são incentivados a valorizar a agressividade, a força fisica, a ação, a dominação e a satisfazer seus desejos, inclusive os sexuais, as meninas são valorizadas pela beleza, delicadeza, sedução, submissão, dependência, sentimentalismo, passividade e o cuidado com os outros.

A questão que surge, diante desse quadro, é saber o que leva a vítima a permanecer em silêncio diante de abusos reiterados por si sofridos mesmo no cenário atual, no qual há uma preocupação tanto do Poder Público quanto da

${ }^{22}$ PIMENTEL, Silvia. PANDJIARJIAN,Valéria. Percepções das Mulheres em relação ao Direito e a Justiça: Legislação, Acesso e Funcionamento. Porto Alegre: SAFE, 2001, p. 132. 
sociedade civil em coibir o exercício da violência contra a mulher. Por que muitas mulheres (ainda) sofrem caladas?

Em resposta a esse questionamento Elena Larrauri ${ }^{23}$ apresenta o seguinte quadro:

Estima-se que mais da metade das mulheres agredidas sofram caladas e não peçam ajuda. Para elas é difícil dar um basta naquela situação. Muitas sentem vergonha ou dependem emocionalmente ou financeiramente do agressor; outras acham que foi só daquela vez ou que, no fundo, são elas as culpadas pela violência; outras não falam nada por causa dos filhos, porque têm medo de apanhar ainda mais ou porque não querem prejudicar o agressor, que pode ser preso ou condenado socialmente. E ainda tem também aquela ideia do ruim com ele, pior sem ele. Muitas se sentem sozinhas, com medo e vergonha. Quando pedem ajuda, em geral, é para outra mulher da família, como a mãe ou irmã, ou então alguma amiga próxima, vizinha ou colega de trabalho. Já o número de mulheres que recorrem à polícia é ainda menor. Isso acontece principalmente no caso de ameaça com arma de fogo, depois de espancamentos com fraturas ou cortes e ameaças aos filhos.

O que se observa, na descrição da autora, é exatamento a materialização do processo de dominação simbólica de que fala Bourdieu: em muitos casos a vítima se mostra incapaz de romper com o ciclo de violência contra sua integridade física e psíquica em decorrência da incorporação da violência a seu cotidiano familiar como algo "natural" e "normal".

Por conseguinte, esbarramos, ainda, em outra questão: o que pode ser feito? Vejamos o que a autora ${ }^{24}$ ainda responde:

${ }^{23}$ LARRAURI, Elena. "É Neutro o Direito Penal?". Revista de Ciências Penais. No ${ }^{\circ}$, p.8. Porto Alegre:SAFE, 2003, p. 128.

${ }^{24}$ Idem, p. 130. 
As mulheres que sofrem violência podem procurar qualquer delegacia, mas é preferivel que elas vão às Delegacias Especializadas de Atendimento à Mulher (DEAM), também chamadas de Delegacias da Mulher (DDM). Há também os serviços que funcionam em hospitais e universidades e que oferecem atendimento médico, assistência psicossocial $e$ orientação jurídica.

A mulher que sofreu violência pode ainda procurar ajuda nas Defensorias Públicas e Juizados Especiais, nos Conselhos Estaduais dos Direitos das Mulheres e em organizações de mulheres. Se for registrar a ocorrência na delegacia, é importante contar tudo em detalhes e levar testemunhas, se houver, ou indicar o nome e endereço delas. Se a mulher achar que a sua vida ou a de seus familiares (filhos, pais etc.) está em risco, ela pode também procurar ajuda em serviços que mantêm casas-abrigo, que são moradias em local secreto onde a mulher e os filhos podem ficar afastados do agressor. Dependendo do tipo de crime, a mulher pode precisar ou não de um advogado para entrar com uma ação na Justiça. Se ela não tiver dinheiro, o Estado pode nomear um advogado ou advogada para defendê-la. Muitas vezes a mulher se arrepende e desiste de levar a ação adiante. Em alguns casos, a mulher pode ainda pedir indenização pelos prejuizos sofridos. Para isso, ela deve procurar a Promotoria de Direitos Constitucionais e Reparação de Danos. Violência contra idosos, crianças e mulheres negras - além das Delegacias da Mulher, a Delegacia de Proteção ao Idoso e o GRADI (Grupo de Repressão e Análise dos Delitos de Intolerância) também podem atender as mulheres que sofreram violência, sejam elas idosas ou nãobrancas, homossexuais ou de qualquer outro grupo que é considerado uma minoria. No caso da violência contra meninas, pode-se recorrer também às Delegacias de Proteção à Criança e ao Adolescente.

Os instrumentos citados pela autora, por naturais que hoje pareçam em nosso cotidiano, não são fruto da atuação espontânea do Estado. Pelo contrário, a criação de leis e entidades de proteção à mulher e de repressão à 
violência contra a mulher são o resultado de décadas de luta por parte de movimentos sociais.

Para compreender como se deu esse processo de afirmação da violência doméstica contra a mulher como problema a ser enfrentado é preciso, antes, compreender como se deu a definição conceitual do problema.

\subsection{Violência doméstica contra a mulher: delimitação conceitual}

A realidade da violência doméstica se mostra particularmente desafiadora a tentativas de definição teórica, uma vez que os conceitos a ela relacionados, como visto, se mostram passíveis de diferentes interpretações, as quais repercutem nas definições obtidas.

Com efeito, como aponta Ana Lucia Sabadel1 ${ }^{25}$, o conceito de violência doméstica originalmente traçado em estudos de orientação feminista na década de 1970 se viu progressivamente ampliado.

Aquilo que inicialmente era entendido como violência física perpetrada contra a mulher passou a ser interpretado de modo amplo, incluindo a violência emocional e psíquica; posteriormente, por influência de outros atores sociais que trabalhavam com a questão da violência doméstica sem adotar $o$ paradigma feminista, o conceito admitiu a inclusão de todas as formas de violência que podem ocorrer no âmbito das relações familiares.

Observando o paradigma feminista, Ana Paula Pires Lucas d'Oliveira aponta com bastante precisão de que modo os conceitos de violência de gênero, violência contra a mulher e violência doméstica se inter-relacionam no discurso acadêmico e na dinâmica dos movimentos sociais:

A "violência contra a mulher", expressão cunhada pelo movimento social feminista há cerca de trinta anos, tentou um

${ }^{25}$ SABADELL, Ana Lucia. Perspectivas jussociológicas da violência doméstica, p. 429-430. 
certo enquadre teórico e prático da questão, mas tampouco teve uma definição precisa e uma teoria explicativa consensual. A teoria feminista é interdisciplinar, bebe das mais variadas fontes e congrega diversas visões do mundo, nem sempre convergentes. Além disto, o debate na área é mais recente e menos caudaloso, apesar de seu rápido crescimento nos últimos 30 anos. O termo diz respeito genericamente a sofrimentos e agressões que estão profundamente arraigados na vida social, e que vinham sendo percebidos como situações normais, sempre que estes sofrimentos e agressões eram dirigidos especificamente às mulheres pelo fato de serem mulheres. O que se enuncia são formas diversas de violência, com expressões variadas e particulares, que compartilham este significado social comum - a iniqüidade de gênero.

A expressão "violência contra a mulher" indica situações tão diversas como a violência fisica, sexual e psicológica cometida por parceiros íntimos, o estupro, o abuso sexual de meninas, o assédio sexual no local de trabalho, a violência contra a homossexualidade, o tráfico de mulheres, o turismo sexual, a violência étnica e racial, a violência cometida pelo Estado, por ação ou omissão, a mutilação genital feminina, a violência e assassinatos ligados ao dote e o estupro em massa nas guerras e conflitos armados ${ }^{26}$.

\section{(...)}

Dentre todas as formas de violência contra a mulher, as agressões fisicas de homens contra mulheres em relações amorosas têm sido especialmente trabalhadas. Só mais recentemente outras situações, como o estupro ou assédio sexual no trabalho, passaram também a ser lembradas (GROSSI, 1995). Este fato corresponde a uma constatação: as mulheres estão em maior risco de agressão física e sexual por pessoas próximas do que por desconhecidos. Esta

${ }^{26}$ In Violência de gênero, necessidades de saúde e uso de serviços em atenção primária. Tese de doutorado. Faculdade de Medicina da USP, 2000, p. 23. 
constatação, antes de estatística, entretanto, é da prática política: essa forma de violência é uma das prioridades consistentes detectadas por ativistas em oficinas com mulheres de todas as camadas sociais e é uma das principais bandeiras do movimento feminista, o que tem incitado a produção de conhecimento científico. Sua conceituação, entretanto, tampouco é consensual.

Uma definição bastante utilizada para estas situações é o de violência doméstica. Nos Estados Unidos a palavra é usada como sinônimo de violência contra a mulher pelo seu marido ELLSBERG, (1998) STARK; FLITCRAFT, (1996). Na América Latina, o termo algumas vezes também é sinônimo de violência contra a mulher, mas diz respeito ainda a agressões sofridas por crianças, especialmente meninas (SAFFIOTI, 1995). Costuma ser dividida em violência física, psicológica e sexual (NATIONAL RESEARCH COUNCIL, 1996, AZEVEDO; GUERRA, 1989), e em alguns casos, também econômica (ELLSBERG, 1998). Aqueles que usam o termo violência doméstica geralmente não a identificam com o campo da violência intra-familiar, e orientam-se pelo referencial feminista.

Utilizaremos violência doméstica para referir à violência contra crianças, idosos e mulheres muito intimos, que convivem ou conviveram no espaço doméstico, e estaremos submetendo tal situação ao olhar do referencial de gênero, ressalvando deste a perspectiva sempre relacional em que, reativa ou não, toda situação de relação na qual as mulheres participam são, elas também, construtoras das interações ali produzidas. Partícipes, muitas vezes, como sujeitos de menor poder e menor valor social, mas sempre, de algum modo, sujeitos de relações estabelecidas. A perda da condição de sujeito é o que reconheceremos como violência de gênero e não mais apenas relações de gênero, como se verá adiante, quando diferenciarmos violência nas relações de poder $^{27}$.

${ }^{27}$ Op. cit., p. 30. 
Há, entretanto, um conceito de violência doméstica contra a mulher que encontra força cogente no Brasil, e que estrutura todo o arcabouço jurídico relativo ao tema: trata-se do art. $5^{\circ}$ da Lei $11.340 / 06^{28}$, o qual dispõe que “configura violência doméstica e familiar contra a mulher qualquer ação ou omissão baseada no gênero que lhe cause morte, lesão, sofrimento físico, sexual ou psicológico e dano moral ou patrimonial”.

O inciso I do mesmo artigo define unidade doméstica como “espaço de convívio permanente de pessoas, com ou sem vínculo familiar, inclusive as esporadicamente agregadas", enquanto o inciso II conceitua família como "comunidade formada por indivíduos que são ou se consideram aparentados, unidos por laços naturais, por afinidade ou por vontade expressa".

Essa definição encontra sua origem na Convenção Interamericana para Prevenir, Punir e Erradicar a Violência contra a Mulher ${ }^{29}$, a qual em seu art. $1^{\circ}$ dispõe que:

"Para os efeitos desta Convenção, entender-se-á por violência contra a mulher qualquer ato ou conduta baseada no gênero que cause morte, dano ou sofrimento físico, sexual ou psicológico à mulher, tanto na esfera pública como na esfera privada".

Em relação aos contextos de ocorrência, o art. $2^{\circ}$ da referida Convenção prevê que:

"Entende-se que a violência contra a mulher abrange a violência: física, sexual e psicológica:

\footnotetext{
${ }^{28}$ BRASIL. Lei 11.340, de 07 de agosto de 2006. Disponivel em:

$<$ http://www.planalto.gov.br/ccivil/_Ato2004-2006/2006/Lei/L113406.htm>. Acesso em 29.05.2011.

29 ORGANIZAÇAO DOS ESTADOS AMERICANOS. Comissão Interamericana de Direitos Humanos. Convenção Interamericana para Prevenir, Punir e Erradicar a Violência Contra a Mulher: Convenção de Belém do Pará. Disponível em: <http://www.cidh.org/Básicos/base8.htm>. Acesso em 29.05.2011.
} 
a) ocorrida no âmbito da família ou unidade doméstica ou em qualquer relação interpessoal, quer o agressor compartilhe, tenha compartilhado ou não a sua residência, incluindo-se, entre outras formas, o estupro, maus-tratos e abuso sexual;

b) ocorrida na comunidade e cometida por qualquer pessoa, incluindo, entre outras formas, o estupro, abuso sexual, tortura, tráfico de mulheres, prostituição forçada, seqüestro e assédio sexual no local de trabalho, bem como em instituições educacionais, serviços de saúde ou qualquer outro local; e

c) perpetrada ou tolerada pelo Estado ou seus agentes, onde quer que ocorra".

Ao interpretar a Lei $\mathrm{n}^{\circ}$ 11.340/06, Maria Berenice Dias entende que o conceito de violência doméstica deve ser entendido a partir da conjugação dos artigos $5^{\circ}$ e $7^{\circ}$ da Lei 11.340/06, e não só da leitura isolada do art. $5^{\circ}$ : o primeiro define o que seja violência doméstica; o segundo, a forma como ela pode ser praticada:

Primeiro a lei define o que seja violência doméstica (art. 5. ${ }^{\circ}$ ): "qualquer ação ou omissão baseada no gênero que lhe cause morte, lesão, sofrimento físico, sexual ou psicológico e dano moral ou patrimonial".

Depois, é estabelecido seu campo de abrangência. A violência passa a ser doméstica quando praticada: a) no âmbito da unidade doméstica; b) no âmbito da família; ou c) em qualquer relação intima de afeto, independente da orientação sexual. ${ }^{30}$

Em que pesem eventuais críticas sobre a (im)precisão da definição legal, é certo que a violência doméstica alcança situações diversificadas e que o legislador procurou conceder à mulher maior proteção da lei, nas situações em

${ }^{30}$ DIAS, Maria Berenice. A lei Maria da Penha na justiça: a efetividade da lei 11.340/2006 de combate à violência doméstica e familiar contra a mulher. $2^{\mathrm{a}}$ ed., São Paulo: RT, 2007, p. 51/52. 
que a privacidade e a intimidade do lar tornam invisíveis a humilhação e o sofrimento a que muitas mulheres são silenciosamente submetidas.

Esse reconhecimento, entretanto, se deve a várias décadas de discussão acerca dos direitos da mulher, discussão essa que inicialmente se deu de modo privilegiado na esfera dos documentos internacionais de Direitos Humanos para posteriormente encontrar amparo na legislação interna brasileira, como se verá a seguir. 


\section{VIOLÊNCIA DOMÉSTICA CONTRA A MULHER: A ABORDAGEM JURÍDICA}

\subsection{A violência contra a mulher como ofensa aos Direitos Humanos}

Protegida ao longo do século XX por convenções e pactos internacionais de Direitos Humanos, a dignidade humana foi alçada pela Constituição Federal de 1988 à categoria de princípio fundamental da ordem jurídica brasileira, vinculando a atuação estatal e as relações entre particulares, declarando-a em seu art. $1^{\circ}$, inciso III, como um dos fundamentos da República Federativa do Brasil, constituída em Estado Democrático de Direito.

Ao prever a dignidade humana como fundamento da República o legislador constituinte não se preocupou apenas com a positivação deste "valor fonte" do pensamento ocidental - assim definido por Celso Lafer ${ }^{31}$. - mas também - e principalmente - buscou estruturar a dignidade humana de forma a lhe atribuir plena efetividade no plano concreto.

De acordo com Ingo Wolfgang Sarlet ${ }^{32}$ a dignidade humana pode ser definida nos seguintes termos:

"Qualidade intrínseca e distintiva de cada ser humano que o faz merecedor do mesmo respeito e consideração por parte do Estado e da comunidade, implicando, neste sentido, um complexo de direitos e deveres fundamentais que assegurem a pessoa tanto contra todo e qualquer ato de cunho degradante e desumano, como que venham a lhe garantir as condições existenciais mínimas para uma vida saudável, além de propiciar e promover sua participação ativa e responsável nos destinos da própria existência e da vida em comunhão com os demais seres humanos."

${ }^{31}$ LAFER, Celso. A reconstrução dos Direitos Humanos - um diálogo com o pensamento de Hannah Arendt. 1 ${ }^{a}$. ed., São Paulo: Companhia das Letras, 1998, p. 50.

32 SARLET, Ingo Wolfgang. Dignidade da pessoa humana e direitos fundamentais na Constituição Federal de 1988. Porto Alegre: Livraria do Advogado, 2001, p. 60. 
Assim, a concepção da dignidade humana como fundamento da República implica no reconhecimento de que o Estado brasileiro é construído e atua tendo em vista as necessidades do ser humano, de modo que dentre suas demais finalidades incumbe ao Estado fomentar e propiciar condições materiais mínimas para que todos tenham condições de viver de modo digno, com respeito à sua integridade física e moral e igualdade de oportunidades.

Desta forma, forçoso concluir que os mais variados atos contrários à dignidade humana constituem violações aos Direitos Humanos. Nesse particular, a violência contra a mulher, nas suas mais diversas manifestações, especialmente a violência doméstica, atinge e avilta de modo particularmente marcante a dignidade das vítimas. Agressões físicas, morais e psicológicas praticadas no ambiente doméstico são uma indiscutível forma de negação dos Direitos Humanos.

Especificamente no tocante às mulheres, vários tratados de Direitos Humanos afirmam os direitos das mulheres como uma especialização dos Direitos Humanos, bem como ser a violência contra a mulher grave ofensa à dignidade humana.

\subsection{Documentos internacionais sobre violência contra a mulher}

O Brasil é signatário dos mais variados documentos produzidos no plano das relações internacionais que asseguram, de forma direta ou indireta, os Direitos Humanos das mulheres, bem como a eliminação de todas as formas de discriminação e violência baseadas no gênero.

Alguns desses documentos têm natureza convencional, isto é, geram obrigações jurídicas para o Estado brasileiro nos planos externo e interno. Outros decorrem de conferências internacionais, cujos resultados são apresentados sob a forma de uma declaração final que não cria obrigações jurídicas aos Estados participantes. As conferências se destinam à criação de consenso na comunidade internacional sobre as matérias nelas discutidas, e cada Estado participante assume a 
responsabilidade de decidir como implementar em seu território, através de políticas públicas, os princípios ali aprovados.

Em ambos os casos, porém, é inegável que a adesão de um Estado aos dispositivos de tais documentos geram importantes conseqüências no plano político, uma vez repudiado o retrocesso em matéria de Direitos Humanos.

\subsubsection{Convenção sobre a Eliminação de Todas as Formas de Discriminação contra a Mulher (1979)}

A Convenção sobre a Eliminação de Todas as Formas de Discriminação contra a Mulher, em vigor desde 1981, é o primeiro tratado internacional que aborda de maneira ampla os Direitos Humanos da mulher ao definir o que é discriminação contra a mulher e estabelecer uma agenda de ações para acabar com essa discriminação. Foi o primeiro instrumento internacional de Direitos Humanos especificamente dirigido à defesa dos direitos das mulheres.

A Convenção propõe aos Estados-parte duas linhas de atuação em prol dos Direitos Humanos da mulher: promoção dos direitos da mulher na busca da igualdade de gênero e repressão a quaisquer discriminações contra a mulher.

A edição da Convenção da Mulher é fruto de décadas de esforços internacionais, visando a proteção e a promoção dos direitos das mulheres de todo o mundo, por meio de iniciativas tomadas dentro da Comissão de Status da Mulher, órgão criado dentro do sistema das Nações Unidas com o objetivo de analisar e criar recomendações de formulações de políticas aos vários países signatários, visando ao aprimoramento da condição da mulher na sociedade.

Partindo da Carta das Nações Unidas e da Declaração Universal dos Direitos Humanos, documentos que declaram que todos os direitos e liberdades humanos devem ser aplicados igualmente a homens e mulheres, sem distinção de qualquer natureza, entre os anos de 1949 e 1962 a Comissão de Status da Mulher elaborou uma série de tratados sobre os direitos das mulheres, embora 
voltados a situações específicas: a Convenção dos Direitos Políticos das Mulheres (1952); a Convenção sobre a Nacionalidade de Mulheres Casadas (1957); a Convenção Sobre o Casamento por Consenso, Idade Mínima para Casamento e Registro de Casamentos (1962).

Esses tratados, sem a pretensão de abordar os Direitos Humanos da mulher de modo amplo, se mostraram especialmente importantes pela proteção e promoção dos direitos da mulher em setores da vida em sociedade nos quais esses direitos eram percebidos pela Comissão como particularmente vulneráveis.

Em 1967 foi publicada a Declaração sobre a Eliminação da Discriminação contra a Mulher, a qual incluía em um único instrumento legal padrões internacionais que articulavam direitos iguais de homens e mulheres. Não houve força política, entretanto, para que a Declaração se efetivasse como um tratado: sua força coerciva se deu somente nos planos moral e político.

Diante da ausência de obrigações jurídicas em decorrência da edição da Declaração sobre a Eliminação da Discriminação contra a Mulher, em 1972 a Comissão sobre o Status da Mulher considerou a possibilidade de edição de um tratado que conferisse força cogente à Declaração.

Tal iniciativa se viu impulsionada pelo Plano Mundial de Ação adotado pela Conferência Mundial do Ano Internacional da Mulher, das Nações Unidas, em 1975, o qual propunha uma Convenção para a Eliminação da Discriminação contra a Mulher, com procedimentos efetivos para sua implementação.

Como resultado desse esforço iniciado com a edição da Declaração sobre a Eliminação da Discriminação contra a Mulher, a Convenção para a Eliminação de Todas as Formas de Discriminação contra a Mulher foi adotada pela Assembléia Geral em 1979. Na resolução de adoção da Convenção, a Assembléia Geral demonstrou expectativas de que ela entrasse em ação em curto prazo. 
A Convenção para a Eliminação de Todas as Formas de Discriminação contra a Mulher é o parâmetro mínimo estabelecido para as ações dos Estados signatários na promoção dos Direitos Humanos das mulheres e na repressão às suas violações, tanto no âmbito público como no privado.

A Convenção vai além das garantias de igualdade e idêntica proteção, viabilizada por instrumentos legais vigentes, estipulando medidas para o alcance da igualdade entre homens e mulheres, independentemente de seu estado civil, em todos os aspectos da vida política, econômica, social e cultural.

\subsubsection{Convenção Interamericana para Prevenir, Punir e Erradicar a Violência contra a Mulher (1994)}

Em 1994, a Assembléia Geral da Organização dos Estados Americanos - OEA aprovou a Convenção Interamericana para Prevenir, Punir e Erradicar a Violência Contra a Mulher, conhecida como Convenção de Belém do Pará, sob a preocupação com a generalização da violência contra as mulheres e considerando que o reconhecimento e o respeito irrestrito a todos os direitos das mulheres são condições indispensáveis para uma sociedade mais justa, solidária e pacífica.

A Convenção de Belém do Pará estabelece que a violência contra a mulher configura uma violação dos Direitos Humanos e das liberdades fundamentais, uma vez que tal violência constitui limitação total ou parcial ao reconhecimento e exercício desses direitos e liberdades pelas mulheres.

A Convenção reconhece, também, que a violência contra as mulheres é uma ofensa à dignidade humana, bem como uma manifestação de relações de poder historicamente desiguais entre mulheres e homens.

Em seu artigo $1^{\mathrm{o}}$ a Convenção define como violência contra a mulher "qualquer ação ou conduta, baseada no gênero, que cause morte, dano ou sofrimento físico, sexual ou psicológico à mulher, tanto no âmbito público como no privado". 
No seu artigo $2^{\circ}$, estabelece que a violência contra a mulher inclui a violência física, sexual ou psicológica que tenha ocorrido na família, na comunidade ou que seja perpetrada ou tolerada pelo Estado ou seus agentes onde quer que ocorra.

Nos termos do artigo $9^{\circ}$ da Convenção, os Estados-parte da OEA assumem a obrigação de considerar a situação de especial vulnerabilidade à violência que a mulher possa sofrer em conseqüência de fatores como sua condição racial e étnica, abrangendo as mulheres integrantes de minorias.

Em seus artigos $7^{\circ}$ e $8^{\circ}$ a Convenção detalha os deveres dos Estados-parte no tocante às políticas de prevenção, erradicação e eliminação da violência contra a mulher, as quais são medidas positivas voltadas para proteger o direito das mulheres a uma vida livre de violências, bem como para o enfrentamento de posturas e práticas que fomentem ou incentivem essa violência.

Dentre as medidas positivas indicadas pela Convenção, destacam-se o incentivo a mudanças legislativas e judiciais, a disseminação de informações sobre os direitos das mulheres e o respeito aos mesmos, a modificação de padrões sócio-culturais, a capacitação de funcionários encarregados de cumprir a lei, a criação de serviços especializados de atendimento a mulheres submetidas a situações de violência e a produção de estatísticas e demais pesquisas sobre a violência contra a mulher.

\subsection{A experiência legislativa brasileira: a criação da Lei $n^{0} 11.340 / 06$}

Após se dar de modo privilegiado na esfera dos documentos internacionais de Direitos Humanos, a questão da violência doméstica contra a mulher obteve inédito tratamento legislativo por meio da Lei $\mathrm{n}^{\circ} 11.340$, de 7 de agosto de 2006, cuja edição é resultado direto da participação do Estado brasileiro no sistema interamericano de proteção dos Direitos Humanos.

A elaboração da Lei $n^{\circ}$ 11.340/06 decorreu de recomendação expressa da Comissão Interamericana de Direitos Humanos, a qual em 20 de agosto 
de 1998 recebeu denúncia apresentada contra o Estado brasileiro em nome de Maria da Penha Maia Fernandes, representada pelo "Centro pela Justiça e pelo Direito Internacional" (CEJIL) e pelo "Comitê Latino-Americano de Defesa dos Direitos da Mulher" (CLADEM), acerca do grave histórico de violência doméstica sofrida pela representada ao longo da década de 80 sem uma resposta adequada da Justiça brasileira.

Com efeito, na denúncia o CEJIL e o CLADEM expuseram à CIDH a situação de inaceitável leniência do Estado brasileiro, notadamente de seu Poder Judiciário, em face de reiteradas práticas violentas de Marco Antônio Heredia Viveiros contra sua então esposa Maria da Penha Maia Fernandes durante o matrimônio.

O caso foi tido como particularmente representativo pelo CEJIL e pelo CLADEM pelo fato de Maria da Penha ter sido vítima de duas tentativas de homicídio por parte do marido no ano de 1983, as quais foram o ponto culminante de um histórico de agressões físicas e verbais contra si praticadas por Marco Antônio.

Na primeira tentativa Marco Antônio simulou um assalto e efetuou um disparo de arma de fogo contra Maria da Penha, mas sem lograr êxito em matá-la; em decorrência das lesões causadas pelo disparo, entretanto, Maria da Penha ficou paraplégica. Na segunda, poucos dias após o disparo, o meio empregado para o pretendido homicídio foi a eletrocussão, também sem êxito.

A investigação policial começou em junho de 1983, e uma vez apurada a materialidade das tentativas de homicídio a denúncia foi apresentada pelo Ministério Público do Estado do Ceará em setembro de 1984.

Em 1991, quase oito anos após o início da ação penal, Marco Antônio foi julgado e condenado a oito anos de prisão. O referido julgamento, entretanto, foi anulado e Marco Antônio se viu submetido a novo julgamento em 1996, no qual foi condenado a uma pena de dez anos e seis meses de prisão. 
O cumprimento da pena se iniciou apenas em 2002, diante da interposição de recursos contra a segunda condenação, e Marco Antônio foi recolhido à prisão por aproximadamente dois anos, conseguindo progressão de pena após cumprir um sexto da pena.

No caso em tela a Comissão Interamericana, de forma inédita, acatou uma denúncia de violência doméstica contra um Estado-parte na Convenção Americana sobre Direitos Humanos.

Diante das peculiaridades do caso apresentado, não só em relação à intensidade das agressões, mas também em relação ao tratamento que o caso recebeu pelo Judiciário brasileiro, entendeu a Comissão Interamericana ter havido violação da Convenção Americana sobre Direitos Humanos (Pacto de San José da Costa Rica) por parte do Estado brasileiro em face da desídia deste em prestar justiça adequadamente e punir o responsável pela violência doméstica praticada contra Maria da Penha.

Entendeu a Comissão que a responsabilidade pela violação aos Direitos Humanos decorrente da demora do Judiciário cearense na persecução penal contra o criminoso deveria ser atribuída ao Estado brasileiro, cuja omissão teria facilitado a instauração de um ambiente propício à violência doméstica, uma vez que não houve evidência socialmente percebida da vontade e efetividade do Estado, como representante da sociedade, em punir esses atos.

O Relatório n. 54 da OEA, reconhecendo a procedência da denúncia apresentada à $\mathrm{CIDH}$, responsabilizou o Estado brasileiro por negligência e omissão frente à violência doméstica, recomendando a adoção de várias medidas ${ }^{33}$, e

\footnotetext{
${ }^{33}$ No Relatório n. 54/01 a CIDH fez as seguintes recomendações ao Estado brasileiro:

“1. Completar rápida e efetivamente o processamento penal do responsável da agressão e tentativa de homicídio em prejuízo da Senhora Maria da Penha Fernandes Maia.

2. Proceder a uma investigação séria, imparcial e exaustiva a fim de determinar a responsabilidade pelas irregularidades e atrasos injustificados que impediram o processamento rápido e efetivo do responsável, bem como tomar as medidas administrativas, legislativas e judiciárias correspondentes.

3. Adotar, sem prejuízo das ações que possam ser instauradas contra o responsável civil da agressão, as medidas necessárias para que o Estado assegure à vítima adequada reparação simbólica e material pelas violações aqui estabelecidas, particularmente por sua falha em oferecer um recurso rápido e
} 
em especial que prosseguisse e intensificasse o estabelecimento de políticas públicas voltadas a evitar a tolerância estatal e o tratamento discriminatório com respeito à violência doméstica contra mulheres no país, particularmente nos seguintes termos ${ }^{34}$ :

a) Medidas de capacitação e sensibilização dos funcionários judiciais e policiais especializados para que compreendam a importância de não tolerar a violência doméstica;

b) Simplificar os procedimentos judiciais penais a fim de que possa ser reduzido o tempo processual, sem afetar os direitos e garantias de devido processo;

c) $\mathrm{O}$ estabelecimento de formas alternativas às judiciais, rápidas e efetivas de solução de conflitos intrafamiliares, bem como de sensibilização com respeito à sua gravidade e às conseqüências penais que gera;

d) Multiplicar o número de delegacias policiais especiais para a defesa dos direitos da mulher e dotá-las dos recursos especiais necessários à efetiva tramitação e investigação de todas as denúncias de violência doméstica, bem como prestar apoio ao Ministério Público na preparação de seus informes judiciais.

e) Incluir em seus planos pedagógicos unidades curriculares destinadas à compreensão da importância do respeito à mulher e a seus direitos reconhecidos na Convenção de Belém do Pará, bem como ao manejo dos conflitos intrafamiliares.

efetivo; por manter o caso na impunidade por mais de quinze anos; e por impedir com esse atraso a possibilidade oportuna de ação de reparação e indenização civil.

4. Prosseguir e intensificar o processo de reforma que evite a tolerância estatal e o tratamento discriminatório com respeito à violência doméstica contra mulheres no Brasil."

In ORGANIZAÇÃO DOS ESTADOS AMERICANOS. Comissão Interamericana de Direitos Humanos. Relatório $\mathbf{n}^{\circ}$ 54/01 - Caso 12.051 - Maria da Penha Maia Fernandes x Brasil. Disponível em: $<\mathrm{http} / / /$ www.cidh.oas.org/annualrep/2000port/12051.htm>. Acesso em 20.06.2011.

34 ORGANIZAÇÃO DOS ESTADOS AMERICANOS. Comissão Interamericana de Direitos Humanos. Relatório $\mathbf{n}^{\circ}$ 54/01 - Caso 12.051 - Maria da Penha Maia Fernandes x Brasil. Disponível em: <http://www.cidh.oas.org/annualrep/2000port/12051.htm>. Acesso em 20.06.2011. 
Diante de tais recomendações, em 2004 foi criado Grupo de Trabalho Interministerial pelo Decreto 5.030/04, sob a coordenação da Secretaria Especial de Políticas para as Mulheres, o qual elaborou o Projeto de Lei 4.559/04, levado ao Congresso sob relatoria da deputada Jandira Feghali.

Após ampla discussão em audiências públicas, inclusive com a apresentação de projeto substitutivo e alterações feitas no Senado Federal, o Projeto de Lei 4.559/04 foi finalmente aprovado e sancionado, tornando-se a atual Lei $\mathrm{n}^{\circ}$ $11.340 / 06^{35}$, popularmente chamada de Lei Maria da Penha em homenagem à requerente.

A Lei, embora se dirija à mulher, não se ocupa de todos os tipos de violência contra o sexo feminino, mas, sim, daquela oriunda de uma questão de gênero e somente nas situações que configure uma violência doméstica ou familiar.

As disposições da Lei $\mathrm{n}^{\mathrm{o}}$ 11.340/06 são "normas de discriminação positiva, ou seja, medidas especiais de caráter temporário destinadas a acelerar a igualdade de fato entre homem e mulher", conforme preceitua o art. $4^{\circ}$, item 1, da Convenção de Belém do Pará:

"Artigo 4". Toda mulher tem direito ao reconhecimento, gozo, exercícios e proteção de todos os Direitos Humanos e às liberdades consagradas pelos instrumentos regionais $e$ internacionais sobre Direitos Humanos. Estes direitos compreendem, entre outros:

a) $O$ direito a que se respeite sua vida.

\footnotetext{
${ }^{35}$ Para maiores detalhes sobre o processo de tramitação e aprovação da Lei $n^{\circ} 11.340 / 06$, temos o trabalho de CORTÊS, Iáris Ramalho. Processo de Criação da Nova Lei sobre Violência Doméstica e Familiar contra a Mulher. Protegendo as Mulheres da Violência Doméstica: Seminário de Capacitação para juízes, procuradores, promotores, advogados e delegados no Brasil. $3^{\mathrm{a}}$. Ed., Brasília: Secretaria Especial de Políticas para as Mulheres, 2006, p. 49-50. Disponível em: $<$ http://www.turminha.mpf.gov.br/para-o-professor/publicacoes/cartilha-violencia-domestica.pdf $>$. Acesso em 19.06.2011.
} 
b) $O$ direito a que se respeite sua integridade fisica, psíquica e moral.

c) O direito à liberdade e à segurança pessoais.

d) O direito a não ser submetida a torturas.

e) $O$ direito a que se refere a dignidade inerente a sua pessoa e que se proteja sua família.

f) O direito à igualdade de proteção perante a lei e da lei;

g) $O$ direito a um recurso simples e rápido diante dos tribunais competentes, que a ampare contra atos que violem seus direitos.

h) O direito à liberdade de associação.

i) $O$ direito à liberdade de professar a religião e as próprias crenças, de acordo com a lei.

j) O direito de ter igualdade de acesso às funções públicas de seu país e a participar nos assuntos públicos, incluindo a tomada de decisões".

A Lei 11.340/06 expressa, em boa medida, o compromisso público assumido pelo Estado brasileiro com o fim da impunidade aos crimes de violência doméstica e familiar, com impacto direto sobre as práticas do sistema judiciário e da polícia.

O modelo preconizado pela Lei $\mathrm{n}^{0} 11.340 / 06$ permite três tipos de atuação: preventiva, psicossocial e punitiva. Não obstante os dois primeiros aspectos terem sido os mais enfatizados pela Lei, foi o último que chamou a atenção da sociedade. 
Há, entretanto, espaço para críticas ao modelo de Justiça Criminal criado pela Lei 11.340/06 para a violência doméstica contra a mulher. Neste sentido, afirmam Luiz Flávio Gomes e Alice Bianchini:

No que concerne, entretanto, ao âmbito criminal, a opção política feita pelo legislador da Lei 11.340/2006 retrata um erro crasso. Ao abandonar o sistema consensual de Justiça (previsto na Lei 9.099/1995), depositou sua fé (e vã esperança) no sistema penal conflitivo clássico (velho sistema penal retributivo). Ambos, na verdade, constituem fontes de grandes frustrações, que somente poderão ser eliminadas ou suavizadas com a terceira via dos futuros Juizados, que contarão com equipe multidisciplinar (mas isso vai certamente demorar para acontecer; os Estados seguramente não criação com rapidez os novos juizados). De qualquer modo, parece certo que no sistema consensuado o conflito familiar, por meio do diálogo e do entendimento, pode ter solução mais vantajosa e duradoura; no sistema retributivo clássico isso jamais será possível.

Quem, nos dias atuais, acredita no sistema penal clássico (inquérito policial, denúncia, instrução probatória, ampla defesa, contraditório, sentença, recursos etc.) e supõe que o funcionamento da Justiça criminal brasileira seja eficiente para resolver alguma coisa, com certeza, não tem a mínima idéia de como ele se desenvolve (ou não o conhece em sua real dimensão).

O sistema penal retributivo clássico é gerenciado por uma máquina policial e judicial totalmente desconexa (seus agentes não se entendem), morosa e extremamente complexa. Trata-se de um sistema que não escuta realmente as pessoas, que não registra tudo que elas falam, que usa e abusa de frases estereotipadas ("o depoente nada mais disse nem lhe foi perguntado" etc.), que só foca o acontecimento narrado no processo, que não permite o diálogo entre os protagonistas do delito (agressor e agredido), que rouba o conflito da vítima (que tem pouca participação no processo), que não a vê em sua singularidade, vitimizando-a pela segunda vez, que canaliza sua energia exclusivamente para a 
punição, que se caracteriza pela burocracia e morosidade, que é discriminatória e impessoal, que é exageradamente estigmatizante, que não respeita (muitas vezes) a dignidade das pessoas, que proporciona durante as audiências espetáculos degradantes, que gera pressões insuportáveis contra a mulher (vitima de violência doméstica) nas vésperas da audiência criminal etc.

Tudo quanto acaba de ser descrito nos autoriza concluir que dificilmente se consegue, no modelo clássico de Justiça penal, condenar o marido agressor. E quando ocorre, não é incomum alcançar a prescrição. Na prática, a "indústria" das prescrições voltará com toda energia. O sistema penal clássico, que é fechado e moroso, que gera medo, opressão etc., com certeza, continuará cumprindo seu papel de fonte de impunidade e, pior que isso, reconhecidamente não constitui meio hábil para a solução desse tenebroso conflito humano que consiste na violência que (vergonhosamente) vitimiza, no âmbito doméstico e familiar, quase um terço das mulheres brasileiras ${ }^{36}$.

A par das críticas, são as inovações trazidas pela Lei $\mathrm{n}^{0}$ 11.340/06 em matéria penal, em particular a alteração ao art. 129 do CP, que serão vistas a seguir neste trabalho. Necessária se faz, contudo, traçar um breve panorama dos mecanismos de enfrentamento da violência doméstica contra a mulher para que seja oportunamente abordada a tipificação de condutas praticadas em tal contexto.

${ }^{36}$ In "Aspectos criminais da Lei de Violência contra a Mulher". Jus Navigandi, Teresina, ano 11, n. 1169, 13 set. 2006. Disponível em: <http://jus.com.br/revista/texto/8916>. Acesso em: 02.01.2012. 
4. O ENFRENTAMENTO DA VIOLÊNCIA CONTRA A MULHER NO BRASIL

\subsection{Panorama institucional}

É certo que a Lei $n^{0} 11.340 / 06$ tem um alcance que não se restringe ao Direito Penal, mas abrange questões pertinentes ao Direito Cível e que compõem grande parte das demandas das mulheres que se dirigem às DEAMs, tais como: partilha de bens, reconhecimento de paternidade, pensões alimentícias, guarda de filhos, etc..

Além disso, a lei prevê uma série de medidas preventivas e de assistência à mulher em situação de violência, por meio de ações integradas do Poder Judiciário, Ministério Público, Defensoria Pública, Polícias e outros órgãos da Segurança Pública, assistência social, saúde, educação e trabalho.

Essas medidas conferem ao Estado e à sociedade civil novas responsabilidades pelo enfrentamento da violência doméstica, apontando a necessidade de uma mudança de mentalidades, atitudes e práticas culturais na produção de novas formas de sociabilidade entre homens e mulheres.

É preciso ressaltar, contudo, que a par das inovações trazidas para o enfrentamento da violência doméstica a Lei $n^{0}$ 11.340/06 faz parte de um longo processo de construção de uma rede de organismos voltados ao atendimento de casos de violência contra a mulher, em especial os ocorridos em contexto doméstico.

Esse processo tem início na resistência feminista contra a violência sofrida pelas mulheres, a qual acarretou mudanças históricas nos processos legislativos, institucionais e jurídicos a partir da década de 1970.

Em conjunto com as demandas pela anistia política de homens e mulheres vítimas da violência militar segmentos do movimento feminista brasileiro aproveitaram a reação à violência institucional do Estado para denunciar a violência cometida contra as mulheres no próprio lar. Campanhas lideradas pelo 
movimento feminista nas décadas de 70 e 80 trouxeram ao público o conhecimento da situação de mulheres agredidas, e muitas vezes mortas, em nome da "honra", do “ciúme", da "submissão" e do "amor" por seus maridos, companheiros e amantes.

Este processo de resistência se fortaleceu com várias estratégias de luta, dentre elas a demanda por políticas públicas a fim de coibir a violência contra a mulher, a qual culminou na criação de organismos judiciais e extrajudiciais voltados ao enfrentamento direto do problema.

Compreender como esses organismos foram criados e estruturados é importante para se compreender como o enfrentamento da violência doméstica contra a mulher se encontra inserido no quadro mais amplo da promoção e defesa dos direitos sociais e do acesso à Justiça no Brasil.

\subsubsection{As Delegacias Especializadas de Atendimento à Mulher (DEAMs)}

A criação das DEAMs é fruto direto do processo de mobilização do movimento feminista brasileiro ocorrido na esteira do processo mais amplo de luta pela redemocratização do Brasil nos anos 70 e 80, e tais delegacias constituem até hoje uma das principais modalidades de atendimento de casos de violência contra a mulher.

Em 1983, acompanhando as eleições dos governos estaduais, foi criado o primeiro Conselho da Condição Feminina em São Paulo, ao qual se seguiu o do Estado de Minas Gerais e o Conselho Nacional dos Direitos das Mulheres (CNDM), criado em 1985. Esses órgãos, de natureza consultiva, foram importantes por marcar o reconhecimento da questão da violência contra a mulher como algo indissociável da pauta de promoção de direitos trazida com o movimento de redemocratização do Brasil, então em curso no seio da sociedade civil.

No entanto, a iniciativa que teve maior expressão e repercussão como política pública foi a criação, em São Paulo, da Delegacia Especial de Atendimento à Mulher (DEAM), integrada ao organograma da Polícia Civil estadual, a qual representou um ganho político significativo ao movimento feminista 
na medida em que sua instituição tornava o Estado responsável pelo controle da violência contra a mulher, até então vista como algo alheio à interferência estatal.

Assim, a violência contra a mulher poderia ser enfrentada por meio da violência legítima monopolizada pelo Estado, para a qual as instituições policiais consistem um meio importante de ação. A primeira DEAM foi criada em São Paulo/SP (1985), seguida pela do Rio de Janeiro/RJ (1986), e posteriormente o modelo se espalhou por todos os Estados da Federação; a despeito da visibilidade que o modelo das DEAMs trouxe para a questão da violência doméstica, entretanto, ainda hoje menos de $10 \%$ dos municípios brasileiros dispõem de DEAMs, sendo que $40 \%$ delas estão instaladas no Estado de São Paulo ${ }^{37}$.

O modelo de atendimento consubstanciado nas DEAMs, embora importante pelo pioneirismo da participação estatal direta na questão da violência contra a mulher, não se mostrou alheio a críticas, como bem sintetiza Lourdes Bandeira ${ }^{38}$ :

Se, por um lado, as DEAMs não se constituíram em uma realidade isolada, pois, estavam inseridas no processo de redemocratização política e do repúdio à violência de forma explícita, processo esse que influiu na elaboração da Constituição de 1988, por outro, assegurar a existência promissora dessas instituições estaria condicionado a ir muito além da "síndrome da queixa", deslocando a compreensão das/os agentes para as tensas dinâmicas da violência de gênero. Isso efetivamente acabou não ocorrendo, estagnou-se na ideia de que o corpo de agentes das DEAMs não poderia transcender de suas funções formais, e, portanto, não poderia assimilar nem a função das assistentes sociais, nem a das psicólogas. As/os agentes e delegadas/os destinadas/os à DEAM assumiam a nomeação mais como uma forma de intolerância, de desprestígio e até mesmo como um castigo, o que lhes causava mais desinteresse do que compromisso

\footnotetext{
${ }^{37}$ Neste sentido: JESUS, Damásio Evangelista de. Violência contra a mulher: aspectos criminais da Lei no 11.340/06. São Paulo: Saraiva, 2010, p. 23/24.

38 "Três décadas de resistência feminista contra o sexismo e a violência feminina no Brasil: 1976 a 2006”. Sociedade e Estado. Brasília, v. 24, n. 2, agosto 2009, p. 413/414 .
} 
com o desempenho profissional, uma vez que deveriam servir-se das tipificações penais existentes, as quais não compreendiam as formas de violências contra a mulher.

A par das insuficiências das DEAMs no tratamento da violência contra a mulher, entretanto, é certo que a experiência brasileira mostra que a intervenção do Estado por meio de um corpo policial especializado e voltado exclusivamente a questões de violência contra a mulher teve efeitos positivos, como ressaltam Mireya Suarez e Lourdes Bandeira ${ }^{39}$ :

a) Tomada de consciência sobre a natureza das sociabilidades violentas que permeiam as relações de senso comum na vida cotidiana das mulheres. Além de causarem dor e sofrimentos físicos e emocionais reais, essas violências minúsculas transcendem a realidade vivida, impregnam o imaginário e, ao mesmo tempo, interferem na própria realidade.

b) Importância das organizações de mulheres em processos grupais; o grupo de apoio às mulheres agredidas, como uma experiência inicial de apoio e estímulo, ajudava-as nas escolhas, seja em busca de coragem e autonomia, seja da necessidade de realizar a denúncia, incentivando-as a procurar a DEAM. Em outras palavras, ao estimular as capacidades de autoestima dessas mulheres, a atuação desses grupos dava-lhes, condição de autonomia para enfrentarem o medo e a perseguição, tornando-se mais livres.

c) A percepção de que a violência está presente, senão em todas, pelo menos na maioria das ações e relações sociais, interpessoais e coletivas é extensiva às instâncias públicas. No caso das DEAMs, a expectativa era de que as mulheres "vitimas" não fossem revitimizadas, à medida que as/os agentes mudassem o padrão de acolhimento e a cultura da escuta, o que poderia gerar, necessariamente, um aprendizado das/dos próprias/os agentes em relação ao seu desempenho.

${ }^{39}$ Apud BANDEIRA, op. cit., p. 414/415. 
d) A crítica elaborada abalou a crença de que a cidadania tem funções de integração social e que garante, ipso facto, a equidade social, regulando as violências interpessoais. Contra-argumentase que a cidadania, tal qual definida formalmente, não poderia absorver e regular os conflitos interpessoais, visto que estes estão mais enraizados nos costumes do que nas desigualdades sociais.

e) O assassinato de mulheres é considerado fato de extrema gravidade, enquanto que as minúsculas agressões cotidianas quase sempre admissiveis - estabelecem novas regras de sobrevivência associadas aos conteúdos morais antigos e recentes que caracterizam o padrão de sociabilidade entre homens $e$ mulheres e intragêneros.

A intervenção policial, porém, não é um fim em si mesmo no Estado Democrático de Direito. As demandas trazidas ao conhecimento do Estado por meio da atuação das DEAMs dependem da intervenção do Poder Judiciário para que seja aplicada a legislação penal em desfavor dos autores de práticas violentas contra mulheres. Necessário se faz, portanto, ver de que modo essas demandas são levadas ao Poder Judiciário e por ele são tratadas para fins penais.

\subsubsection{Os Juizados de Violência Doméstica e Familiar contra a Mulher}

A partir de 1995, os crimes comuns de violência denunciados nas DEAMs, tais como lesões corporais e ameaças, passaram a ser tratados no âmbito dos Juizados Especiais Civis e Criminais (JECRIMs), criados pela Lei $\mathrm{n}^{\circ}$ 9.099/95 e destinados a julgar delitos considerados de menor potencial ofensivo, ou seja, aqueles crimes de pena máxima não superior a 1 (um) ano, limite esse que posteriormente foi ampliado para 2 (dois) anos pela Lei $1^{\circ} 11.313 / 06$.

A atribuição de competência aos JECRIMs para conhecer e julgar infrações contra a mulher tidas como de menor potencial ofensivo geraram insatisfações e grande resistência por parte do movimento feminista, pelos seguintes motivos: 
a) os delitos de violência contra a mulher perderam o caráter de crimes de ação pública incondicionada e foram transformados em crimes de ação pública condicionados à representação da vítima, o que significa que a ação penal só tinha início a partir de denúncia expressada pela vítima de processar criminalmente o acusado;

b) a atuação das DEAMs teria sido restringida pela Lei $n^{\circ} 9.099 / 95$, a qual previa ê como documento principal para a apuração dos crimes de menor potencial ofensivo o Termo Circunstanciado de Ocorrência (TCO), menos formal do que o inquérito policial e sem a mesma carga simbólica deste;

c) a Lei $n^{\circ} 9.099 / 95$, ao suprimir a realização do inquérito policial, teria esvaziado a competência investigativa das DEAMs;

d) a Lei $n^{0}$ 9.099/95, ao prever a transação penal com a aplicação de prestações pecuniárias e outras alternativas penais, teria vinculado os crimes de violência contra a mulher a medidas desacreditadas como elementos punitivos em nossa sociedade;

e) a Lei $n^{0}$ 9.099/95 estabeleceu mecanismos quase compulsórios de conciliação entre as partes, caracterizando a imposição de um "fim" ao conflito sem que suas reais causas fossem de fato enfrentadas.

Se, por um lado, a Lei $n^{\circ}$ 9.099/95 trouxe novas competências aos espaços de atuação jurídica dos JECRIMs, criados a partir de uma tríade articulada (celeridade dos procedimentos, intencionalidade relativa de promover a conciliação e atribuição de penas alternativa e/ou pecuniárias), por outro a conseqüência imediata foi que, dos casos em que os JECRIMs passaram a atuar, cerca de $70 \%$ eram relativos à violência contra a mulher e, destes, mais de $50 \%$ das denúncias acabavam efetivando-se em "acordo de conciliação", assinado pelas partes.

Portanto, levando-se em conta a natureza da violência doméstica e a relação de poder presente nesses crimes, ao incluir as ameaças e as agressões físicas no rol dos crimes de menor potencial ofensivo, a Lei $n^{\circ}$ 9.099/95 
teria estimulado a desistência das mulheres, através das audiências de conciliação, de processar seus maridos ou companheiros agressores, e com isso reforçado a cultura de impunidade que leva os homens a agredirem as mulheres.

A Lei $n^{0}$ 9.099/95 ao tratar a violência contra a mulher na ordem semântica de menor potencial ofensivo, não ofereceu as soluções que as vítimas necessitavam, uma vez que a centralidade desta lei dirigia-se ao agressor-réu. As vítimas mulheres eram praticamente silenciadas mediante a pergunta: "a senhora quer continuar a discutir o assunto?"

Essa pergunta, profundamente inibidora e indutora de resposta, propiciava que, na continuidade da audiência, fosse apresentado o termo com o acordo conciliatório para ser assinado, e, logo após, o casal regressava para casa, supostamente já reconciliado. Escondia-se por trás dessa conciliação, sem dúvida, a garantia da manutenção dos laços familiares, e, com isso, sucumbia a causa do conflito. $\mathrm{Na}$ realidade, acabava sendo destinada ao locus familiar a responsabilidade de produzir a reconciliação do conflito entre as partes.

Além do efeito descriminalizante da Lei $\mathrm{n}^{\circ}$ 9.099/95, uma das suas consequências perversas era o fato de, em muitas situações, a própria mulher agredida ter que trabalhar para pagar a prestação pecuniária ou a "cesta básica", uma vez que o marido, em muitos casos, encontrava-se desempregado quando retornava do ato conciliatório.

Diante dos problemas encontrados na experiência de enquadramento dos casos de violência contra a mulher à sistemática dos Juizados Especiais Criminais a Lei $n^{0}$ 11.340/06 inovou ao dispor sobre a criação dos Juizados de Violência Doméstica e Familiar Contra a Mulher (JVDFCM).

A respeito da criação dos JVDFCM, afirma Sérgio Ricardo de Souza:

O legislador fixou claramente que os Juizados de Violência Doméstica e Familiar Contra a Mulher são órgãos jurisdicionais, 
integrantes da justiça ordinária dos Estados e do Distrito Federal, excluindo a integração deles a alguma justiça especializada ou mesmo á justiça federal. (...) O legislador preferiu facultar a criação destes juizados, já que usou o verbo poderão, e não, deverão, isso provavelmente para evitar a alegação de desrespeito à autonomia das Unidades Federadas. ${ }^{40}$

No mesmo sentido, afirma Leda Maria Hermann sobre o art. 14 da Lei ${ }^{\circ} 11.340 / 06$ :

(...) a redação do artigo não é imperativa, e nem poderia ser. Em princípio, por ser iniciativa exclusiva dos Tribunais de Justiça dos Estados propor ao Poder Legislativo respectivo a criação de novas varas e a alteração da organização e da divisão judiciárias. (...) sendo de competência das Assembléias legislativas, mediante proposta dos Tribunais de Justiça Estaduais, legislar sobre a matéria. $^{41}$

Os JVDFCM possuem competência cível e criminal, mas sua atuação prática é predominantemente criminal. O objetivo principal da criação desta modalidade de juizado é garantir que a mulher que sofreu violência doméstica e familiar tenha total amparo e facilidade de acesso à Justiça.

Ainda, a criação dos JVDFCM busca possibilitar ao juiz uma visão ampla de todo o contexto de violência doméstica contra a mulher, evitando assim decisões contraditórias, como poderia ocorrer se as competências estivessem dividas entre o juiz criminal e o juiz de Família.

Nos casos de autoridades que possuem foro privilegiado por prerrogativa de função, serão julgadas pelo órgão competente, visto que o foro especial irá se sobrepor sobre os juizados de violência doméstica e familiar contra a mulher.

${ }^{40}$ In Comentários à Lei de Combate à Violência Contra a Mulher - Lei Maria da Penha 11.340/06. Curitiba: Juruá Editora, 2007, p. 87.

${ }^{41}$ In Maria da Penha - Lei com nome de Mulher. São Paulo: Editora Servanda, 2007, p. 164. 
Também nos casos em que ocorre tentativa ou consumação de crimes dolosos contra a vida a competência não será destes juizados, e sim do Tribunal do Júri, bem como nos casos em que o agressor comete crime contra a vida da vítima em situação que caracterize violência doméstica ou familiar.

Portanto, quanto ao julgamento, sempre prevalecerá o Tribunal do Júri em desfavor dos Juizados criados pela Lei 11.340/06, visto que a norma que cria os JVDFCM é infraconstitucional.

Nesse particular, o Superior Tribunal de Justiça assim decidiu:

"Ressalvada a competência do Júri para julgamento do crime doloso contra a vida, seu processamento, até a fase de pronúncia, poderá ser pelo Juizado de Violência Doméstica e Familiar contra a mulher, em atenção à Lei 11.340/06" (STJ, HC 73.161/SC, Rel. Min. Convocada Jane Silva, j. 29.08.2007, DJ 17.09.2007, p.317)

Uma vez que, os tribunais do júri não têm competência para processar e julgar matérias cíveis, estas serão decididas pelos JVDFCM e encaminhados ao Tribunal do Júri apenas os crimes contra a vida e conexos, ficando as demais providências, como alimentos e separação de corpos, a critério dos Juizados de Violência Doméstica e Familiar contra a Mulher.

Quanto à competência territorial, esclarece Leda Maria Hermann que "o legislador revela a preocupação sistêmica, presente ao longo do texto legal, de valorização e proteção da ofendida, conferindo-lhe o privilégio de definir, por sua opção, a competência territorial"42. A finalidade do dispositivo é diminuir obstáculos à implementação das regras estabelecidas pela Lei nº 11.340/06.

A lei também estabelece diretrizes quanto a renúncia à representação da ofendida em seu artigo 16, a saber:

${ }^{42}$ Op. cit., p. 165. 
Art. 16. Nas ações penais públicas condicionadas à representação da ofendida de que trata esta lei, só será admitida a renúncia à representação perante o juiz, em audiência especialmente designada com tal finalidade, antes do reconhecimento da denúncia e ouvido o Ministério Público.

As ações penais públicas condicionadas são aquelas em que a propositura da ação depende da manifestação da vítima. Há essa necessidade nos casos dos crimes que o interesse individual da vítima se sobrepõe sobre o interesse coletivo.

A representação, para Sérgio Ricardo de Souza:

(...) consiste em uma narrativa dos fatos com todas as informações que possam servir à apuração, a qual poderá ser previamente escrita e entregue à autoridade policial, ao órgão de execução do Ministério Público ou ao Juiz, ou ainda, consistir em um relato oral, hipótese esta em que será tomada por escrito ${ }^{43}$. (2007, p. 93)

A representação deverá ser apresentada em seis meses, sob pena de decadência, com a contagem do prazo iniciando-se a partir do conhecimento da ocorrência do fato e da sua autoria.

O referido artigo também prevê a retratabilidade da representação, mas para isso será necessário que tal retratação se faça em audiência especialmente designada para este fim, antes do oferecimento da denúncia e que anteriormente seja ouvido o Ministério Público.

Sérgio Ricardo de Souza esclarece acerca do artigo 16 da Lei 11.340/06:

A condição de procedibilidade que autoriza a instauração do inquérito policial e da futura ação penal, denominada

${ }^{43}$ In Comentários à Lei de Combate à Violência Contra a Mulher - Lei Maria da Penha 11.340/06. Curitiba: Juruá Editora, 2007, p. 93. 
'representação'”, é retratável, ou seja, a vítima pode voltar atrás e decidir que não pretende mais que o Estado apure o fato e puna pó infrator e, desde que a retratação ocorra antes do oferecimento da denúncia, tem como conseqüência a extinção da punibilidade em relação àquele fato. Nos crimes caracterizados pela violência doméstica e familiar contra a mulher essa retratação tem se constituido em uma das formas mais comuns dessa anômala extinção de punibilidade, principalmente em decorrência das pressões levadas a efeitos por parentes e pela própria pessoa indiciada como agressor. ${ }^{44}$

Portanto, com os requisitos impostos pela lei em comento, fica mais difícil que a vítima desista da representação quando se sentir ameaçada ou sobre pressão por parte do agressor.

Segundo a lei a retratação deve ser feita antes do recebimento da denúncia pelo Ministério Público, e este deverá participar da audiência designada para retratação. Importante ressaltar que o MP não tem poder para impedir que a vítima se retrate, pode, no máximo, tentar argumentar para que esta pense melhor na decisão: não tem o promotor de justiça poder para opor-se à renúncia da representação, se for esta a vontade da vítima.

\subsubsection{Outros órgãos governamentais e não-governamentais}

Em paralelo às instituições do sistema de Justiça voltadas à apreciação de casos de violência contra a mulher (DEAMs) e posterior aplicação da legislação pertinente (JVDFCM) identifica-se a existência de órgãos diversos que, em maior ou menor medida, se ocupam do referido problema.

$\mathrm{Na}$ esfera federal foi instituída a Secretaria de Políticas para as Mulheres (SPM), com status de ministério, por meio da Medida Provisória ${ }^{\circ} 103$,

\footnotetext{
${ }^{44}$ Op. cit., p. 94.
} 
de $1^{\mathrm{o}}$ de janeiro de 2003, posteriormente convertida na Lei $\mathrm{n}^{\mathrm{o}} 10.683 / 2003^{45}$. A SPM foi criada com a finalidade de desenvolver ações conjuntas com todos os Ministérios e Secretarias Especiais, tendo como desafio a incorporação das especificidades das mulheres nas políticas públicas e o estabelecimento das condições necessárias para a sua plena cidadania.

A SPM tem competência legal para as seguintes ações:

a) assessorar direta e imediatamente o Presidente da República na formulação, coordenação e articulação de políticas para as mulheres;

b) elaborar e implementar campanhas educativas e não discriminatórias de caráter nacional;

c) elaborar o planejamento de gênero que contribua na ação do governo federal e das demais esferas de governo;

d) promover a igualdade de gênero; articular, promover e executar programas de cooperação com organismos nacionais e internacionais, públicos e privados, voltados à implementação de políticas para as mulheres;

e) promover o acompanhamento da implementação de legislação de ação afirmativa e definição de ações públicas que visem ao cumprimento dos acordos, convenções e planos de ação assinados pelo Brasil, nos aspectos relativos à igualdade entre mulheres e homens e de combate à discriminação.

Diversos Estados da Federação possuem Secretarias próprias para a defesa e o planejamento de políticas voltadas à mulher, dentre os quais se

${ }^{45}$ BRASIL. Lei $\mathbf{n}^{\mathbf{0}} \mathbf{1 0 . 6 8 3}$, de 28 de maio de 2003. Dispõe sobre a organização da Presidência da República e dos Ministérios, e dá outras providências. Disponível em: $<$ http://www.planalto.gov.br/ccivil_03/LEIS/2003/L10.683.htm>. Acesso em 10.07.2011. 
pode citar: Alagoas $^{46}$, Distrito Federal ${ }^{47}$, Goiás $^{48}$, Maranhão ${ }^{49}$, Paraíba ${ }^{50}$, Pernambuco $^{51}$ e Rio Grande do $\mathrm{Sul}^{52}$, entre outros.

No Estado de São Paulo a formulação de políticas públicas voltadas às mulheres, aí compreendido o enfrentamento da violência contra a mulher, é realizada pelo Conselho Estadual da Condição Feminina ${ }^{53}$, entidade vinculada à Secretaria Estadual de Relações Institucionais.

Em paralelo aos órgãos governamentais, porém, não se pode esquecer da importância das organizações não-governamentais na discussão das questões relacionadas à violência contra a mulher.

Surgido à margem da inércia do Poder Público em face da violência contra a mulher, o movimento feminista se articulou e até hoje se articula em torno de instituições como o Instituto Patrícia Galvão, o Comitê LatinoAmericano de Defesa dos Direitos da Mulher (CLADEM) e o Centro Feminista de Estudos e Assessoria (CFEMEA), entre outras, cuja trajetória faz parte, como já

46 Alagons. Secretaria de Estado da Mulher, da Cidadania e dos Direitos Humanos. Disponível em: <http://www.mulherecidadania.al.gov.br/. Acesso em 02.10.2012.

47 DISTRITO FEDERAL. Secretaria de Estado da Mulher. Disponível em: $<$ http://www.mulher.df.gov.br/>. Acesso e, 02.01.2012.

${ }^{48}$ GOIÁS. Secretaria de Estado de Políticas para Mulheres e Promoção da Igualdade Racial. Disponível em: <http://www.semira.go.gov.br/>. Acesso em 02.10.2012.

${ }^{49}$ MARANHÃO. Secretaria de Estado da Mulher. Disponível em: <http://www.semu.ma.gov.br/>. Acesso em 02.01.2012.

50 PARAÍBA. Secretaria de Estado da Mulher e da Diversidade Humana. Disponível em: $<$ http://www.paraiba.pb.gov.br/mulher-e-da-diversidade-humana>. Acesso em 02.01.2012.

51 PERNAMBUCO. Secretaria de Estado da Mulher. Disponível em: $<$ http://www2.secmulher.pe.gov.br/web/secretaria-da-mulher>. Acesso em 02.01.2012.

52 RIO GRANDE DO SUL. Secretaria de Políticas para as Mulheres do Rio Grande do Sul. Disponível em: <http://www.spm.rs.gov.br/>. Acesso em 02.01.2012.

53 SÃO PAULO. Conselho Estadual da Condição Feminina. Disponível em: < http://www.condicaofeminina.sp.gov.br/>. Acesso em 02.01.2012. 
visto, do processo em andamento nas últimas três décadas em prol da criação de leis e instituições voltadas à proteção da mulher contra práticas violentas no Brasil ${ }^{54}$.

\footnotetext{
${ }^{54}$ Uma relação bastante abrangente das principais organizações não-governamentais de promoção e defesa dos direitos das mulheres, muitas das quais diretamente engajadas no enfrentamento da violência contra a mulher dentro e fora do contexto doméstico, pode ser encontrada em < http://www.agenciapatriciagalvao.org.br/index.php?option=com_content\&view=article\&id=94\&catid $=103>$. Acesso em 02.01.2012.
} 


\section{A TUTELA PENAL DA INTEGRIDADE FÍSICA NO DIREITO BRASILEIRO}

\subsection{Evolução histórico-legislativa}

Necessário se faz, nesta etapa do trabalho, breve digressão sobre a tutela penal da integridade física no ordenamento jurídico brasileiro para que seja oportunamente estudado o subsistema criado pela Lei $\mathrm{n}^{\circ} 11.340 / 06$ para a tutela penal da integridade física da mulher no seio das relações domésticas.

A integridade física do indivíduo constitui, sem sombra de dúvida, um dos mais antigos objetos de tutela penal. Nesse sentido, afirma Paulo Antônio Ribeiro Fraga ${ }^{55}$ :

"Os maiores bens jurídicos que possui o homem são: a vida e a integridade física. E contra êstes bens dois crimes principais avultam: o homicídio e a lesão corporal. Assim, entre todos os povos, mesmo aquêles que não atingiram elevado grau de civilização, os dois crimes são punidos com penas mais graves".

Segundo o mesmo autor, disposições penais relacionadas à lesão da integridade física de outrem são encontradas nas sociedades mais antigas, e em alguns casos com grau de detalhamento próprio de legislações mais recentes.

A título de ilustração, destaca o autor que o Código de Hamurábi já distinguia como figuras delitivas distintas as lesões cometidas contra os pais, contra a mulher grávida que resultasse em aborto; praticadas em rixa e mesmo lesões praticadas por imprudência ou negligência, enquanto a legislação rabínica já levava em conta as circunstâncias agravantes e atenuantes, punindo com maior rigor as lesões cometidas contra os pais, com premeditação ou com emprego de arma e

${ }^{55}$ FRAGA, Paulo Antônio Ribeiro. As lesões corporais e o Código Penal. Rio de Janeiro: Freitas Bastos, 1959, p. 29. 
com menor rigor as lesões praticadas por imprudência ou em resposta a uma ofensa $^{56}$.

No mesmo sentido, também no Direito brasileiro é possível observar que há muito a integridade física constituiu objeto de preocupação do legislador penal, como se verá a seguir.

No Livro V das Ordenações Filipinas, vigente em matéria penal no território brasileiro até $1830^{57}$, encontra-se pioneira disposição sobre as lesões corporais em seu Título XXXVI ${ }^{58}$, assim redigido:

"Das penas pecuniárias dos que matam, ferem ou tiram arma na Corte

(...) E o que tirar arma na Côrte, ou em seus arrabaldes, ou no lugar onde a Caza da Suplicação stiver sem nós, ou seus arrabaldes, ou na Cidade de Lisboa, e seus arrabaldes, e com ella não ferir, pague dous mil réis da Cadêa; e se com ella ferir, pague trez mil réis, a metade para a Piedade, e a outra para o Meirinho da Corte, ou Alcaide da dita Cidade, ou para a pessoa, que os der a prisão; e se for aleijamento, pague o dobro.

E se de propósito tirar arma, ferir ou aleijar, pague o dobro do que pagaria, sendo em rixa; e isto além das penas pecuniárias conteúdas nos Foraes dos lugares, onde forem feitos os ditos malefícios."

\footnotetext{
${ }^{56}$ FRAGA, Paulo Antônio Ribeiro. As lesões corporais e o Código Penal, p. 29/30.

${ }^{57}$ Em que pese o fato das Ordenações Manuelinas se encontrarem em vigor entre 1521 e 1603 período no qual a empreitada colonial portuguesa no Brasil já se encontrava em andamento Zaffaroni e Pierangeli apontam com bastante propriedade que somente em 1609 foi organizada a administração da justiça no território brasileiro, com a criação da Relação da Bahia, razão pela qual afirmam que o Direito Penal que efetivamente vigorou no Brasil Colônia foi o Livro V das Ordenações Filipinas. (ZAFFARONI, Eugenio Raúl; PIERANGELLI, José Henrique. Manual de direito penal brasileiro: parte geral. 4. ed. São Paulo: Editora Revista dos Tribunais, 2002. p. 201)
}

58 PORTUGAL. Ordenações Filipinas. Título XXXVI do Livro V. Disponível em: $<$ http://www.ci.uc.pt/ihti/proj/filipinas/15p1187.htm>. Acesso em 14.06.2011. 
Chama a atenção, aqui, a parte final do referido Título, a qual ao mesmo tempo em que declara impunível a lesão praticada pela mulher assegura expressamente ao marido o direito de castigar fisicamente sua mulher sem receber qualquer represália, desde que para tanto não empregue arma:

"E estas penas não haverão lugar no que tirar arma, ou ferir em defensão de seu corpo e vida, nem nos escravos captivos que, com páo, ou pedra ferirem, nem na pessoa, que for de menos idade de quinze annos, que sem qualquer arma ferir, ou matar, ora seja captivo, ora fôrro, nem nas mulheres, que com páo ou pedra ferirem, nem nas pessoas, que tirarem armas para estremar e não ferirem acidentalmente, nem em quem castigar criado, ou discipulo, ou sua mulher, ou seu filho, ou seu scravo, (...). Porém, se em castigando ferirem com arma, não serão relevados das ditas penas."

Essa desigualdade de tratamento em favor do marido, chancelando como lícitas agressões praticadas contra a mulher a título de castigo ou corretivo, é condizente com o espírito das Ordenações do Reino, pautadas pelo estabelecimento de classes e privilégios em matéria penal.

Nesse sentido, bem observa René Ariel Dotti ${ }^{59}$ que as Ordenações Filipinas "desvendaram durante dois séculos a face negra do Direito Penal", uma vez que "em contraste com uma tipologia de agentes marcada por ferro em brasa, existiam as categorias privilegiadas de sujeitos que gozavam de imunidade ou especial tratamento punitivo: fidalgos, cavalheiros, desembargadores, escudeiros, etc.."

Com a independência do Brasil em 1822, entretanto, surgiu a perspectiva de criação de uma legislação penal autenticamente brasileira, pautada pelos princípios iluministas então em voga.

${ }^{59}$ DOTTI, René Ariel. Curso de direito penal: parte geral. 2 ed. Rio de Janeiro: Forense, 2005, p. 182. 
Nesse sentido a Constituição de 1824 previu expressamente em seu art. 179, $\S 18$, como um dos deveres do recém-criado império, a criação de um Código Criminal fundado nas sólidas bases da justiça e da equidade. Somente em 1830, entretanto, é que o mandamento constitucional se viu concretizado pela edição do Código Criminal do Império.

Com o Código Criminal a tutela penal da integridade física passou a ser feita nos termos da Secção IV do Capítulo I do Título II da Parte Terceira, denominada "Ferimentos e outras offensas physicas" e assim redigida ${ }^{60}$ :

"Art. 201. Ferir ou cortar qualquer parte do corpo humano, ou fazer qualquer outra offensa physica, com que se cause dôr ao offendido.

Penas - de prisão por um mez a um anno, e multa correspondente á metade do tempo.

Art. 202. Se houver, ou resultar mutilação, ou destruição de algum membro, ou orgão, dotado de um movimento distincto, ou de uma funcção especifica, que se pôde perder, sem perder a vida.

Penas - de prisão com trabalho por um a seis annos, e de multa correspondente á metade do tempo.

Art. 203. A mesma pena se imporá no caso, em que houver, ou resultar inhabilitação de membro, ou orgão, sem que comtudo fique destruido.

Art. 204. Quando do ferimento, ou outra offensa physica resultar deformidade.

Penas - de prisão com trabalho por um a tres annos, e multa correspondente á metade do tempo.

60 BRASIL. Lei Imperial de $\mathbf{1 6}$ de dezembro de 1830. Disponível em: $<\mathrm{http} / / /$ www.planalto.gov.br/ccivil_03/Leis/LIM/LIM-16-12-1830.htm>. Acesso em 16.06.2011. 
Art. 205. Se o mal corporeo resultante do ferimento, ou da offensa physica produzir gravo incommodo de saude, ou inhabilitação de serviço por mais de um mez.

Penas - de prisão com trabalho por um a oito annos, e de multa correspondente á metade do tempo.

Art. 206. Causar á alguem qualquer dôr physica com o unico fim de o injuriar.

Penas - de prisão por dous mezes a dous annos, e de multa correspondente a duas terças partes do tempo.

Se para esse fim se usar de instrumento aviltante, ou se fizer offensa em lugar publico.

Penas - de prisão por quatro mezes a quatro annos, e de multa correspondente a duas terças portes do tempo."

Com o Código Criminal a singela previsão do Título XXXVI do Livro V das Ordenações Filipinas deu lugar a um detalhado sistema de punições contra autores de lesões corporais, com diferentes sanções conforme a quantidade e a qualidade do dano causado à vítima, de orientação francesa, conforme expõe Paulo Antônio Ribeiro Fraga ${ }^{61}$ :

"Quanto às lesões corporais, dividiram-se os códigos do século passado. Duas diretrizes foram seguidas: uns, orientados pelo código francês de 1810, fazendo consistir a lesão na ofensa à integridade fisica, ofensa material.

Outros seguiram com orientação diversa, tais como os códigos italiano e alemão, para os quais o crime se consubstancia na ofensa do corpo, e também na ofensa da saúde e até da mente.

${ }^{61}$ FRAGA, Paulo Antônio Ribeiro. As lesões corporais e o Código Penal, p. 32. 
O código de 1830 seguiu o sistema francês, o mesmo acontecendo com o código de 1890."

Desapareceu, aqui, a odiosa eximente quanto à agressão do marido contra a mulher, aplicando-se indistintamente a homens e mulheres as normas dos art. 201 a 206.

Aliás, em sentido inverso, houve por bem o legislador prever uma circunstância agravante segundo a qual a menor capacidade da vítima em face do agente, inclusive em razão do sexo, implicava em maior punição deste último ${ }^{62}$ :

“Art. 16. São circumstancias agravantes:

$6^{\circ}$ Haver no delinquente superioridade em sexo, forças, ou armas, de maneira que o offendido não pudesse defender-se com probabilidade de repellir a offensa."

Chama a atenção o fato da chamada injúria real - isto é, a ofensa por vias de fato ou violência com o fim específico de atingir a vítima em sua dignidade - ter sido elencada pelo legislador entre os crimes contra a integridade física (art. 206).

O CP de 1890, por sua vez, pouco inovou no tratamento das lesões corporais, mantendo a orientação do Código Criminal ao prever diversas modalidades delitivas conforme a extensão do dano causado ${ }^{63}$ :

Art. 303. Offender physicamente alguem, produzindo-lhe dôr ou alguma lesão no corpo, embora sem derramamento de sangue:

62 BRASIL. Lei Imperial de $\mathbf{1 6}$ de dezembro de $\mathbf{1 8 3 0}$. Disponível em: $<$ http://www.planalto.gov.br/ccivil_03/Leis/LIM/LIM-16-12-1830.htm>. Acesso em 16.06.2011.

63 BRASIL. Decreto $\mathbf{n}^{\mathbf{0}} \mathbf{8 4 7}$, de 11 de outubro de 1890. Disponível em: $<$ http://www6.senado.gov.br/legislacao/ListaPublicacoes.action?id=66049>. Acesso em 16.06.2011. 
Pena - de prisão cellular por tres mezes a um anno.

Art. 304. Si da lesão corporal resultar mutilação ou amputação, deformidade ou privação permanente do uso de um orgão ou membro, ou qualquer enfermidade incuravel e que prive para sempre o offendido de poder exercer o seu trabalho:

Pena-de prisão cellular por dous a seis annos.

Paragrapho unico. Si produzir incommodo de saude que inhabilite o paciente do serviço activo por mais de 30 dias:

Pena - de prisão cellular por um a quatro annos.

Art. 305. Servir-se alguem, contra outrem, de instrumento aviltante no intuito de causar-lhe dôr physica e injurial-o:

Pena - de prisão cellular por um a tres annos.

Art. 306. Aquelle que por imprudencia, negligencia ou por inobservancia de alguma disposição regulamentar, commetter ou for causa involuntaria, directa ou indirectamente, de alguma lesão corporal, sera punido com a pena de prisão cellular por quinze dias a seis mezes.

A partir do CP de 1890 o crime de ofensa à integridade física alheia passou a ser denominado "lesões corporais", a qual perdura até hoje. Manteve, ainda, a injúria real entre os crimes contra a segurança da pessoa e da vida, embora de modo imperfeito, pois como bem aponta Paulo Antônio Ribeiro Fraga "só a admitia quando fosse empregado instrumento aviltante. De onde, a 'bofetada' não ser incriminada"64.

${ }^{64}$ FRAGA, Paulo Antônio Ribeiro. As lesões corporais e o Código Penal, p. 32. 
Foi mantida, como circunstância agravante, a "superioridade em sexo, força ou armas", conforme o artigo $39, \S 5^{\circ}$, e o parágrafo $9^{\circ}$ do mesmo artigo inovou ao definir como agravante a circunstância de a vítima ser o "ascendente, descendente, conjuge, mestre, discipulo, tutor, tutelado, amo, domestico, ou de qualquer maneira legitimo superior ou inferior do agente", indicando, embora de modo implícito, que circunstâncias de relação de convivência doméstica entre a vítima e o agressor conferiam ao crime maior gravidade.

A Consolidação das Leis Penais de 1932, no tocante às lesões corporais, reproduziu o quanto disposto no CP de 1890 sem inovar no tema.

É com o CP de 1940 que o crime de lesões corporais, incorporando elementos dos diplomas anteriores, assume sua atua configuração típica. A dor física deixa de ser elemento do tipo e a injúria real passa a ser elencada entre os crimes contra a honra, atendendo a reivindicações doutrinárias.

As lesões corporais passam a ser classificadas em leves, graves, gravíssimas e seguida de morte - com a gravidade das lesões sendo determinada pela extensão do dano causado.

\subsection{Estrutura típica do atual art. 129 do CP}

O crime de lesões corporais consiste em qualquer dano causado sem animus necandi (intenção de matar) à integridade física ou à saúde de outrem, aí incluída tanto a fisiológica quanto a mental. Compreende o delito, pois, toda e qualquer ofensa ocasionada à normalidade funcional do corpo ou organismo humano, sem se limitar à normalidade anatômica.

Quer como alteração da integridade física ou como perturbação funcional, a lesão corporal é sempre resultante de um ato de violência exercida contra a vítima, violência esta que pode ser de qualquer ordem, qualquer que seja o meio empregado para produzi-la. 
A violência que não atinge o indivíduo em sua normalidade funcional não é compreendida no art. 129 do $\mathrm{CP}$, podendo ser eventualmente enquadrada no crime de injúria real (art. $140, \S 2^{\circ}, \mathrm{CP}$ ) ou na contravenção penal de vias de fato (art. 21, Lei das Contravenções Penais) quando dotada de algum significado: intervenções ínfimas, tais como uma picada de alfinete, não são passíveis de enquadramento penal à luz do Princípio da Ofensividade.

Da mesma forma, a autolesão não se faz penalmente relevante salvo quando ofensiva a um bem jurídico diverso da integridade físicopsíquica daquele que se autolesiona (ex.: aborto, estelionato, etc.).

O crime de lesões corporais consiste em qualquer dano doloso ou culposo ocasionado à integridade física ou psíquica de outrem (esta última compreendida na expressão "saúde", em sentido lato) sem animus necandi, podendo tal dano acarretar ou não as consequências previstas nos $\S \S 1^{\circ}, 2^{\circ}$ e $3^{\circ}$ do art. 129: inexistindo tais consequências, trata-se da chamada lesão corporal leve, a que corresponde a forma simples do art. 129, caput, do CP.

Embora tenha enunciado dois aspectos (integridade corporal e saúde) no caput do art. 129 o legislador não teve a intenção de criar dois tipos penais distintos, mas tão somente estabelecer um conceito amplo de lesão e com isso reforçar a proteção da integridade individual nos aspectos físicos e psíquicos, considerando o indivíduo como um todo, sem limitações de suas atividades no âmbito das relações sociais.

Por ofensa à integridade corporal entende-se todo e qualquer dano de importância à normalidade anatômica dos tecidos e dos órgãos humanos, e, como ofensa à saúde as alterações desfavoráveis ao normal funcionamento do organismo, aí compreendidas as alterações fisiológicas de qualquer natureza, inclusive aquelas relativas às funções mentais e psíquicas.

Funções como consciência, atenção, concentração, percepção e memória, entre outras, se reportam à atividade funcional do cérebro, e sua alteração 
sem qualquer das consequências previstas nos $\S \S 1^{\circ}, 2^{\circ}$ e $3^{\circ}$ do art. 129 configuram lesão corporal leve.

Em paralelo à forma simples ou leve, o art. 129 do CP traz nos já mencionados $\S \S 1^{\circ}, 2^{\circ}$ e $3^{\circ}$ formas de lesão corporal qualificadas pelo resultado.

Aqui o legislador optou por estabelecer casos taxativos nos quais há uma tipicidade distinta, e mais gravosa, daquela prevista no caput do art. 129. Os resultados elencados pelo legislador independem de dolo ou culpa do agente na sua produção, ressalvada a superveniência de causa relativamente independente, a qual limita a imputação aos fatos anteriores ao resultado (art. 13, § $\left.1^{\circ}, \mathrm{CP}\right)$.

$\mathrm{O} \S 1^{\circ}$ do art. 129 do $\mathrm{CP}$ estabelece as chamadas lesões corporais graves, prevendo como resultados que qualificam o crime: a incapacidade da vítima para as ocupações habituais por mais de 30 (trinta) dias (inciso I); o perigo de vida (inciso II); a debilidade permanente de membro, sentido ou função (inciso III); e a aceleração de parto (inciso IV).

A ocupação de que trata o inciso I é genérica: não se trata necessariamente de trabalho remunerado, de modo a abranger não só atividades economicamente produtivas, mas também as demais atividade próprias e costumeiras da vítima, sejam elas de natureza social, política, artística, religiosa, desportiva, etc.. Trata-se, aqui, de limitação ao exercício da personalidade da vítima por meio de suas ações habituais.

Já o inciso II trata do perigo de vida, compreendido como a probabilidade concreta e presente de morte da vítima como consequência da lesão por si sofrida. O perigo deve ser diretamente proveniente da lesão, e não da circunstância na qual ela se deu ou do meio empregado pelo agente. Tampouco basta, para a configuração desta forma qualificada, que a lesão seja meramente idônea para acarretar o perigo de vida em abstrato: exige-se, aqui, que o perigo seja concretamente observado. 
O inciso III, por sua vez, trata da debilidade permanente de membro, sentido ou função, consistente no enfraquecimento, redução ou diminuição da capacidade funcional. A debilidade deve se dar de modo permanente, isto é, irreversível, ou ao menos por prazo indeterminado, e implica em efetiva limitação do membro, sentido ou função afetada: exemplos disso são a amputação ou a redução de movimentos de um único dedo, a qual prejudica a funcionalidade do restante da mão sem inutilizá-la por completo.

Por fim, a aceleração de parto prevista no inciso IV ocorre quando há a expulsão do feto dotado de capacidade de sobrevivência extra-uterina como consequência da lesão corporal. É necessário que o agente tenha ao menos o potencial de conhecer a condição gravídica da vítima: se esta era ignorada pelo agente e este não tinha meios de percebê-la, haverá erro de tipo inescusável e a forma agravada restará excluída.

$\mathrm{O} \oint 2^{\mathrm{o}}$ do art. 129 trata da chamada lesão corporal gravíssima, a qual se caracteriza por resultados de maior intensidade e lesividade do que os previstos no parágrafo anterior. São eles: a incapacidade permanente para o trabalho (inciso I); a enfermidade incurável (inciso II); a perda ou inutilização de membro, sentido ou função (inciso III); a deformidade permanente (inciso IV); e a ocorrência de aborto (inciso V).

$\mathrm{Na}$ incapacidade permanente para o trabalho o indivíduo deve restar privado da possibilidade física ou psíquica de aplicar-se à realização de atividade lucrativa em caráter definitivo ou, ainda, de tal modo que não seja possível estimar um prazo para a cessação da incapacidade.

Não é a profissão específica da vítima que determina a ocorrência da incapacidade, mas sim o trabalho considerado em forma genérica, sob pena de se admitir que uma mesma lesão, sofrida por vítimas distintas, tenha repercussões jurídico-penais distintas por conta da profissão específica de cada um: a perda de um único dedo, que configuraria lesão grave em condições normais, poderia impossibilitar um músico profissional de exercer seu mister. 
A enfermidade incurável de que trata o inciso II, por sua vez, pode ser de natureza física, fisiológica ou mesmo psíquica, desde que haja ao menos a probabilidade de não haver cura em prazo determinado. Há, aqui, a necessidade de desvio da normalidade funcional como derivado da enfermidade, desvio esse que se mostra particularmente gravoso por conta da incurabilidade.

No tocante ao inciso III há que se fazer distinção entre perda e inutilização. Entende-se por perda a extirpação decorrente de mutilação (determinada pela própria lesão) ou pela amputação (determinada por intervenção medica necessária para salvar a vida da vítima em face da lesão), enquanto a inutilização compreende a cessação das funções próprias do membro, sentido ou função afetada pela lesão. Aqui a irreparabilidade da perda ou inutilização também se faz necessária para configurar o delito.

Já a deformidade permanente de que trata o inciso IV se caracteriza pela modificação depreciativa da condição estética da vítima, a qual deverá ser atingida de tal modo que a deformidade cause constrangimento à vítima no trato social. Não é necessário que a desfiguração seja tida como horripilante ou inumana, bastando que haja efetiva diminuição da capacidade da vítima em qualquer aspecto de sua vida em sociedade. A irreparabilidade da lesão por meios naturais, sem intervenção humana, é o elemento que determina a permanência da deformidade.

Por fim, o inciso $\mathrm{V}$ trata da ocorrência de aborto como resultado da lesão corporal. Diferentemente do que ocorre no art. $129, \S 1^{\circ}$., IV, aqui há a expulsão de feto que, embora vivo, não tem condições de sobrevivência extrauterina, sobrevindo a morte do feto após a expulsão.

A morte da vítima, por sua vez, é compreendida como qualificadora da lesão corporal no $\S 3^{\circ}$. Trata-se de resultado consistente na cessação completa das funções vitais do organismo, o qual ocorre de modo culposo uma vez que o dispositivo é expresso ao estipular que para a configuração do delito "as circunstâncias evidenciam que o agente não quis o resultado, nem assumiu o risco de produzi-lo", o que afasta a incidência tanto do dolo direto quanto do eventual. 
No $\S 4^{\circ}$ do art. 129 há uma causa de diminuição de pena aplicável a todas as modalidades de lesões corporais, segundo a qual "se o agente comete o crime impelido por motivo de relevante valor social ou moral ou sob o domínio de violenta emoção, logo em seguida a injusta provocação da vítima, o juiz pode reduzir a pena de um sexto a um terço".

Já o $§ 5^{\circ}$ dispõe sobre circunstâncias que habilitam o juiz a substituir a pena de prisão por multa nas lesões corporais leves: a ocorrência da lesão corporal nas circunstâncias do $\S^{\circ}$ (inciso I) e a constatação de lesões recéprocas entre agente e vítima (inciso II). Para a caracterização do inciso II é necessário que se identifique de modo exato a relação entre pelo menos uma vítima e pelo menos um agressor; caso contrário, havendo múltiplos e indeterminados agentes envolvidos em agressões recíprocas tratar-se-á do delito de rixa (art. 137, CP).

$\mathrm{O} \S 6^{\circ}$ do art. 129 dispõe sobre as lesões corporais culposas. Trata-se, aqui, de modalidade culposa do crime de lesões corporais leves, uma vez que nas lesões graves e gravíssimas a intenção do agente quanto ao resultado que qualifica o crime é irrelevante, enquanto nas lesões seguidas de morte exige-se que o resultado seja culposo.

No $\S 7^{\circ}$ há causa de aumento de pena para as lesões corporais praticadas nas circunstâncias do $\S 4^{\circ}$ do art. 121 , isto é, pela "inobservância de regra técnica de profissão, arte ou ofício, ou se o agente deixa de prestar imediato socorro à vítima, não procura diminuir as conseqüências do seu ato, ou foge para evitar prisão em flagrante", bem como "se o crime é praticado contra pessoa menor de 14 (quatorze) ou maior de 60 (sessenta) anos", enquanto o $\$ 8^{\circ}$ estende ao agente que pratica lesões corporais culposas a possiblidade do juiz deixar de aplicar a pena "se as conseqüências da infração atingirem o próprio agente de forma tão grave que a sanção penal se torne desnecessária".

Os $\S \S 9^{\circ}$ a 11 do art. 129 , por fim, serão objeto de considerações no capítulo a seguir, posto que diretamente relacionados à prática de violência doméstica. 


\section{VIOLÊNCIA DOMÉSTICA CONTRA A MULHER E TUTELA PENAL}

\subsection{Evolução legislativa}

Diante da variedade de manifestações de violência contra a mulher no âmbito das relações domésticas, recentemente o legislador brasileiro optou por conferir expressa tutela penal à sua caracterização física.

Como visto anteriormente, as relações domésticas passaram a ter relevância no sistema penal inicialmente na condição de agravante genérica, inovação trazida com o Código Criminal de 1830 e mantida pelas codificações posteriores.

A partir da ratificação do Brasil à Convenção de Belém do Pará, entretanto, o legislador se preocupou em dar tratamento específico à matéria. Essa preocupação, num primeiro momento, não se traduziu na edição de normas incriminadoras específicas.

Inicialmente foi editada a Lei $\mathrm{n}^{\mathrm{o}} 10.455 / 02^{65}$, a qual incluiu no parágrafo único do artigo 69 da Lei 9.099/95 a previsão de uma medida cautelar de natureza penal, a qual previa a possibilidade do agressor ser compulsoriamente afastado do lar em casos de violência doméstica:

Art. 19. O parágrafo único do art. 69 da Lei $n^{\circ}$ 9.099, de 26 de setembro de 1995, passa a vigorar com a seguinte redação:

"Art. 69

Parágrafo único. Ao autor do fato que, após a lavratura do termo, for imediatamente encaminhado ao juizado ou assumir o compromisso de a ele comparecer, não se imporá prisão em 65 BRASIL. Lei $\mathbf{1 0 . 4 5 5}, \quad$ de $\quad \mathbf{1 3}$ de maio de 2002. Disponível em:
$<$ <http://www.planalto.gov.br/ccivil/LEIS/2002/L10455.htm>. Acesso em 21.06.2011. 
flagrante, nem se exigirá fiança. Em caso de violência doméstica, o juiz poderá determinar, como medida de cautela, seu afastamento do lar, domicílio ou local de convivência com a vitima."(NR)

De acordo com Ana Lucia Sabadell ${ }^{66}$ a Lei $n^{\text {o }} 10.455 / 02$, embora positiva no sentido de indicar que o legislador foi "paulatinamente ocupando-se da questão da violência doméstica", se mostrou de duvidosa utilidade prática, uma vez que "a lei não definiu o que se entendia por violência doméstica, dificultando a aplicação do referido artigo".

Outra inovação, menos tímida no enfrentamento da questão da violência contra a mulher, veio com a Lei $\mathrm{n}^{\mathrm{o}} 10.778 / 03^{67}$, a qual trouxe ao ordenamento brasileiro a primeira definição legal de violência contra a mulher, derivada da Convenção de Belém do Pará, ao disciplinar a obrigatoriedade da notificação compulsória dos casos de violência doméstica atendidos na rede de serviços de saúde:

Art. $1^{\circ}$ Constitui objeto de notificação compulsória, em todo o território nacional, a violência contra a mulher atendida em serviços de saúde públicos e privados.

$\S 1^{\circ}$ Para os efeitos desta Lei, deve-se entender por violência contra a mulher qualquer ação ou conduta, baseada no gênero, que cause morte, dano ou sofrimento físico, sexual ou psicológico à mulher, tanto no âmbito público como no privado.

$\S 2^{\circ}$ Entender-se-á que violência contra a mulher inclui violência física, sexual e psicológica e que:

\footnotetext{
${ }^{66}$ SABADELL, Ana Lucia. Perspectivas jussociológicas da violência doméstica: efetiva tutela de direitos fundamentais e/ou repressão penal, p. 440.

67 BRASIL. Lei 10.778, de $\mathbf{2 4}$ de novembro de 2003. Disponível em: $<$ http://www.planalto.gov.br/ccivil/LEIS/2003/L10.778.htm>
} 
I - tenha ocorrido dentro da família ou unidade doméstica ou em qualquer outra relação interpessoal, em que o agressor conviva ou haja convivido no mesmo domicílio que a mulher e que compreende, entre outros, estupro, violação, maus-tratos e abuso sexual;

II - tenha ocorrido na comunidade e seja perpetrada por qualquer pessoa e que compreende, entre outros, violação, abuso sexual, tortura, maus-tratos de pessoas, tráfico de mulheres, prostituição forçada, seqüestro e assédio sexual no lugar de trabalho, bem como em instituições educacionais, estabelecimentos de saúde ou qualquer outro lugar; $e$

III - seja perpetrada ou tolerada pelo Estado ou seus agentes, onde quer que ocorra.

$\S 3^{\circ}$ Para efeito da definição serão observados também as convenções e acordos internacionais assinados pelo Brasil, que disponham sobre prevenção, punição e erradicação da violência contra a mulher.

Aqui também a intenção do legislador, embora louvável, também merece críticas no entender de Ana Lucia Sabadell ${ }^{68}$, uma vez que a assimilação direta de normas de direito internacional não atenderia a "necessidade de adaptação ao contexto nacional".

Assim, para a referida autora a Lei "não estabeleceu o conceito de violência doméstica, de forma a suprir a lacuna criada pela lei 10.455/2002".

Diante da questionável eficácia das iniciativas anteriores o legislador optou por enfrentar a questão da violência contra a mulher no plano da

${ }^{68}$ SABADELL, Ana Lucia. Perspectivas jussociológicas da violência doméstica: efetiva tutela de direitos fundamentais e/ou repressão penal, p. 440. 
tutela da integridade física, o que fez por meio de alterações na redação original do art. 129 do CP.

\subsection{A Lei n ${ }^{10.886 / 04}$}

A edição da Lei $n^{\circ} 10.886 / 04$ criou uma figura qualificada dentro do artigo 129 do CP, o qual passou a prever uma pena mínima de 6 meses no caso de lesão corporal leve decorrente de violência doméstica, denominando expressamente essa figura qualificada como crime de "violência doméstica"69:

Art. $1^{o}$. O art. 129 do Decreto-Lei no 2.848, de 7 de dezembro de 1940 - CP, passa a vigorar acrescido dos seguintes $\$ \S 9^{\circ}$ e 10 :

"Art. 129.

Violência Doméstica

$\S 9^{\circ}$. Se a lesão for praticada contra ascendente, descendente, irmão, cônjuge ou companheiro, ou com quem conviva ou tenha convivido, ou, ainda, prevalecendo-se o agente das relações domésticas, de coabitação ou de hospitalidade:

Pena-detenção, de 6 (seis) meses a 1 (um) ano.

$\S 10$. Nos casos previstos nos $\S \S 10$ a 30 deste artigo, se as circunstâncias são as indicadas no $\$ 90$ deste artigo, aumenta-se a pena em 1/3 (um terço)." (NR)

A referida lei, entretanto, não escapou de críticas por autorizados setores da doutrina. Apontou-se, por exemplo, que o aumento da pena mínima se mostrava irrelevante diante da gravidade da conduta e da intenção do

69 BRASIL. Lei 10.886, de 17 de junho de 2004. Disponível em: $<$ http://www.planalto.gov.br/ccivil_03/_Ato2004-2006/2004/Lei/L10.886.htm>. Acesso em: 21.06.2011. 
legislador de dar tratamento diferenciado à violência contra a mulher, como observa Damásio Evangelista de Jesus ${ }^{70}$ :

Não obstante tivesse o legislador, no referido parágrafo, aumentado a pena mínima cominada ao autor da conduta para 6 meses de detenção (a 1 ano), enquanto na lesão corporal simples, prevista no art. 129, caput, do CP, comine sanção menor, também de detenção, de 3 meses a 1 ano, na verdade não houve alteração substancial, uma vez que o fato, por exemplo, de o marido agredir a esposa, ferindo-a, continuava a ser tratado da mesma maneira. Diante disso, o objetivo da lei, que, em obediência à Constituição Federal, era tornar mais grave a resposta penal em face da prática de violência doméstica contra a mulher, havia sido integralmente frustrado.

Com a agravação da pena mínima de detenção, de 3 para 6 meses, não ficara afastada a aplicação da transação penal (art. 76 da Lei n. 9.099/95) nem do sursis processual (art. 89 da mesma lei), sendo cabiveis as penas restritivas de direitos (art. 44 do CP).

De ver-se, contudo, que, no dia a dia, o reforço esperado pelo legislador com a edição de leis novas se mostrava infantil e inútil.

Além da ineficácia no plano repressivo, a edição da Lei $n^{\circ}$ 10.886/04 teria representado um retrocesso na abordagem jurídica da violência contra a mulher, no entender de Ana Lucia Sabadell" ${ }^{71}$, na medida em que "apesar de seus defeitos, a Lei 10.778/2003 mantinha referência a questão de gênero, vínculo

${ }^{70}$ JESUS, Damásio Evangelista de. Violência contra a mulher: aspectos criminais da Lei $\mathbf{n}^{\mathbf{0}}$ 11.340/06. São Paulo: Saraiva, 2010, p. 50-51.

${ }^{71}$ SABADELL, Ana Lucia. Perspectivas jussociológicas da violência doméstica: efetiva tutela de direitos fundamentais e/ou repressão penal, p. 440. 
este que foi rompido com a Lei 10.886/2004, criando também a dúvida quanto à compatibilidade entre a definição de violência apresentada nesta última lei e a Convenção da OEA de 1994, ratificada pelo Brasil”.

\subsection{A Lei no 11.340/06}

Foi com a edição da Lei $n^{0} 11.340 / 06^{72}$ que a violência contra a mulher no plano doméstico recebeu tratamento sistemático em matéria penal.

O artigo 44 da referida lei deu nova redação ao $\S 9^{\circ}$ do art. 129 do CP, alterando-lhe a pena máxima de modo significativo e mantendo o nomen juris de "violência doméstica", bem como mantendo a causa de aumento de pena do $\S 10$ para as lesões graves, gravíssimas e seguidas de morte, inserida pela Lei $\mathrm{n}^{\circ}$ 10.886/04:

Art. 44. $O$ art. 129 do Decreto-Lei $n^{\circ} 2.848$, de 7 de dezembro de 1940 (CP), passa a vigorar com as seguintes alterações:

“Art. 129.

$\S 90$ Se a lesão for praticada contra ascendente, descendente, irmão, cônjuge ou companheiro, ou com quem conviva ou tenha convivido, ou, ainda, prevalecendo-se o agente das relações domésticas, de coabitação ou de hospitalidade:

Pena - detenção, de 3 (três) meses a 3 (três) anos.

$\S 11$. Na hipótese do $\S 9^{\circ}$ deste artigo, a pena será aumentada de um terço se o crime for cometido contra pessoa portadora de deficiência." (NR)

72 BRASIL. Lei 11.340, de 07 de agosto de 2006. Disponivel em: $<$ http://www.planalto.gov.br/ccivil/_Ato2004-2006/2006/Lei/L113406.htm>. Acesso em 26.05.2011. 
Essa alteração da pena máxima se mostra relevante na medida em que o crime deixa de ser considerado de menor potencial ofensivo de acordo com o critério adotado pela Lei 9.099/95 em seu art. 61 - pena máxima não superior a 2 anos - medida essa de inegável simbolismo em face das expectativas sociais de enfrentamento da violência doméstica.

A reforçar o reconhecimento do crime de violência doméstica como sendo de maior gravidade a despeito das penas mínima e máxima, o legislador dispôs expressamente sobre a inaplicabilidade da Lei $\mathrm{n}^{\circ}$ 9.099/95 e de seus institutos despenalizadores ao delito em tela por meio do art. 41 da Lei $n^{\circ} 11.340 / 06$ :

Art. 41. Aos crimes praticados com violência doméstica e familiar contra a mulher, independentemente da pena prevista, não se aplica a Lei no 9.099, de 26 de setembro de 1995.

Ainda, foi alterada a redação da alínea "f” do inciso II do art. 61 do CP para se prever de modo claro a violência contra a mulher nos termos da Lei $\mathrm{n}^{\mathrm{o}} 11.340 / 06$ como agravante genérica:

Art. 43. A alínea $f$ do inciso II do art. 61 do Decreto-Lei no 2.848, de 7 de dezembro de 1940 (CP), passa a vigorar com a seguinte redação:

“Art. 61.

II -

f) com abuso de autoridade ou prevalecendo-se de relações domésticas, de coabitação ou de hospitalidade, ou com violência contra a mulher na forma da lei específica;" (NR)

Nos termos do art. $7^{\circ}$ da Lei 11.340/06 a violência doméstica e familiar contra a mulher se caracteriza por ao menos cinco grandes grupos de condutas, todas com relevância penal: 
Art. 7o São formas de violência doméstica e familiar contra a mulher, entre outras:

I - a violência física, entendida como qualquer conduta que ofenda sua integridade ou saúde corporal;

II - a violência psicológica, entendida como qualquer conduta que lhe cause dano emocional e diminuição da auto-estima ou que lhe prejudique e perturbe o pleno desenvolvimento ou que vise degradar ou controlar suas ações, comportamentos, crenças e decisões, mediante ameaça, constrangimento, humilhação, manipulação, isolamento, vigilância constante, perseguição contumaz, insulto, chantagem, ridicularização, exploração $e$ limitação do direito de ir e vir ou qualquer outro meio que the cause prejuizo à saúde psicológica e à autodeterminação;

III - a violência sexual, entendida como qualquer conduta que a constranja a presenciar, a manter ou a participar de relação sexual não desejada, mediante intimidação, ameaça, coação ou uso da força; que a induza a comercializar ou a utilizar, de qualquer modo, a sua sexualidade, que a impeça de usar qualquer método contraceptivo ou que a force ao matrimônio, à gravidez, ao aborto ou à prostituição, mediante coação, chantagem, suborno ou manipulação; ou que limite ou anule o exercício de seus direitos sexuais e reprodutivos;

IV - a violência patrimonial, entendida como qualquer conduta que configure retenção, subtração, destruição parcial ou total de seus objetos, instrumentos de trabalho, documentos pessoais, bens, valores e direitos ou recursos econômicos, incluindo os destinados a satisfazer suas necessidades;

$V$ - a violência moral, entendida como qualquer conduta que configure calúnia, difamação ou injúria. 
A amplitude das conceituações apresentadas no art. $7^{\circ}$ permite concluir que pelo fato da violência doméstica alcançar situações diversificadas o legislador procurou conceder à mulher a maior proteção possível em situações nas quais a privacidade e a intimidade do lar ocultam o sofrimento ao qual muitas mulheres são cotidiana e silenciosamente submetidas.

\subsection{Há um crime de violência doméstica contra a mulher?}

A despeito das inovações por si trazidas a Lei $n^{\circ}$ 11.340/06 não se vê livre de críticas: algumas de cunho conservador, apontando que a lei teria dado tratamento excessivamente protetivo à mulher em detrimento do homem, outras reiterando críticas feitas às leis anteriores no sentido de que a violência contra a mulher deveria ser alvo de uma figura típica autônoma, uma vez que o art. 129, $\S 9^{\circ}$, do CP não contemplaria de modo privilegiado a violência contra a mulher.

De fato, a Lei $\mathrm{n}^{\mathrm{o}} 11.340 / 06$ não trouxe ao ordenamento jurídico brasileiro uma figura típica com o nomen juris de "violência doméstica contra a mulher". Mas isso não impede que se reconheça que em relação ao crime de lesões corporais a violência doméstica contra a mulher encontra, sim, tratamento mais gravoso do que lesões corporais praticadas em contextos diversos, o que também ocorrerá com crimes como a injúria, a ameaça, etc..

Isso porque, tomando as lesões corporais como referencial, além da previsão típica do art. $129, \S \S 9^{\circ}$ e $10^{\circ}$, do $\mathrm{CP}$, a qual faz referência ao contexto de violência doméstica sem ressalva entre homem e mulher, temos a nova redação da agravante do art. 61, II, “f”, do CP, a qual faz menção expressa à violência contra a mulher na forma da lei específica.

Assim, temos que em relação à violência contra a mulher o art. 61, II, “f”, do CP é norma penal em branco que encontra seu complemento nos art. $5^{\circ}$ e $7^{\circ}$ da Lei $n^{\circ} 11.340 / 06$.

A combinação do art. $129, \S \S 9^{\circ}$ e 10 , com a referida agravante faz com que em relação à mulher tenhamos a possibilidade de se ter um 
tratamento diferenciado à violência doméstica contra ela praticada, uma vez que em relação ao homem as demais previsões do art. 61, II, "f" do CP que são próprias do contexto doméstico - prevalência de relações domésticas, de coabitação ou de hospitalidade - não poderão ser consideradas em desfavor do agente por constituírem, também, elementares do crime do art. $129, \S \S 9^{\circ}$ e 10 , sob pena de inaceitável bis in idem.

Assim, tomando como exemplo as lesões corporais leves, na ocorrência destas contra mulher em situação de violência doméstica o crime do art. 129 , $\S 9^{\circ}$, do $\mathrm{CP}$ necessariamente terá a pena mínima majorada, ressalvada a existência de circunstâncias atenuantes em favor do agente.

Embora na prática o incremento de pena oriundo da agravante genérica nem sempre se faça sensível, é certo que do ponto de vista sistêmico a combinação dos artigos mencionados supre a ausência de um tipo específico. 


\section{A MEDICINA LEGAL E SUAS CONTRIBUIÇÕES PARA A QUESTÃO DA VIOLÊNCIA DOMÉSTICA CONTRA A MULHER}

\subsection{Considerações preliminares}

Uma vez delimitado o problema da violência doméstica contra a mulher como realidade social e como objeto de tutela jurídica tanto no plano internacional quanto no plano do ordenamento jurídico brasileiro, com destaque para o tratamento penal do tema, a questão que se coloca é a seguinte: a Medicina Legal pode contribuir para a compreensão e o enfrentamento da violência doméstica contra a mulher?

A resposta, como se verá a seguir, é positiva. Isso porque a violência doméstica contra a mulher apresenta nítidas características de problema de saúde pública, em razão do que se exige que a análise da questão seja feita empregando referenciais diversos, em apoio à simples dogmática jurídica.

A Medicina Legal, entendida como "a aplicação dos conhecimentos médicobiológicos na elaboração e execução que deles carecem" na definição clássica de Flamínio Fávero $^{73}$, pode e deve contribuir para a compreensão da violência doméstica contra a mulher e para a formulação de políticas de enfrentamento do problema, notadamente por meio do aprimoramento das normas jurídico-penais destinadas ao sancionamento de práticas violentas.

Sem a pretensão de se esgotar o tema, seguem algumas das possibilidades de emprego da Medicina Legal no tratamento da questão.

7.2. A mensuração dos casos de lesão corporal decorrente de violência doméstica contra a mulher

Uma das possibilidades de contribuição da Medicina Legal para o estudo da violência doméstica contra a mulher reside na verificação de que modo a violência doméstica contra a mulher se manifesta empiricamente, em especial para se observar quais as possíveis peculiaridades desse fenômeno em termos médico-legais se comparado com outras práticas violentas.

\footnotetext{
${ }^{73}$ In Medicina Legal. $1^{\text {o }}$ vol., $4^{\text {a }}$ Ed.. São Paulo: Martins Editora, 1951, p. 27.
} 
Essa verificação por meio de pesquisas de campo se apresenta duplamente útil: além de identificar a dinâmica real do fenômeno juridicamente tutelado, fornece subsídios para eventuais aperfeiçoamentos legislativos que se façam necessários.

Há um número considerável de pesquisas de campo feitas no Brasil nas últimas três décadas sobre o fenômeno da violência contra a mulher, tanto em sentido mais amplo quanto com foco na questão específica da violência doméstica, as quais apresentam resultados nem sempre convergentes quanto à dimensão do problema.

No início da década passada a Organização Mundial de Saúde (OMS) coordenou um estudo sobre violência contra mulher que constituiu um marco tanto em abrangência quanto pela forma como foi realizado: foram coletados dados acerca de mais de 24.000 mulheres, situadas em 10 países com diferentes backgrounds culturais: Bangladesh, Brasil, Etiópia, Japão, Namíbia, Peru, Samoa, Sérvia e Montenegro, Tailândia e República Unida da Tanzânia.

\section{O WHO Multi-country Study on Women's Health and}

Domestic Violence against Women (WHO VAW Study) ${ }^{74}$ se caracterizou pela aplicação de uma metodologia padronizada em todos os locais de coleta de dados, com o que se buscou superar algumas dificuldades encontradas em outros estudos e trabalhos anteriores sobre violência contra as mulheres, e produziu resultados que permitem comparar e analisar os vários ambientes culturais em estudo.

No caso brasileiro ${ }^{75}$ o levantamento de dados foi realizado por meio da aplicação de questionários em inquérito domiciliar, abrangendo os anos de 2000 e 2001, em dois contextos diversos: o município de São Paulo (SP), a maior

\footnotetext{
${ }^{74}$ WHO multi-country study on women's health and domestic violence against women. Disponível em http://www.who.int/reproductivehealth/publications/violence/9241593512/en/index.html (em inglês). Acesso em 10.12.2011.

${ }^{75}$ Publicado como D'OLIVEIRA, Ana Flávia Pires Lucas et al. "Fatores associados à violência por parceiro íntimo em mulheres brasileiras". Revista de Saúde Pública, São Paulo, v. 43, n. 2, abril 2009, p. 299/311.
} 
cidade brasileira, e 15 municípios pertencentes à Zona da Mata do estado de Pernambuco (ZMP).

A escolha do município de São Paulo se justifica em termos estatísticos pelo fato de se tratar da maior cidade brasileira, com uma população atual estimada em 11 milhões de habitantes ${ }^{76}$ (o que corresponde a aproximadamente 17\% da população brasileira ${ }^{77}$ ), o que confere representatividade aos resultados obtidos naquela localidade em relação à ocorrência de casos de violência contra a mulher em contexto urbano.

Já a região da Zona da Mata de Pernambuco apresenta características que a tornam bastante representativa do contexto sócio-cultural observado no interior do Brasil, em especial no ambiente rural: falta de autonomia financeira das mulheres, comportamentos de sujeição destas a homens (pais, maridos, etc.) no convívio familiar como elemento cultural bastante arraigado, etc..

$\mathrm{Na}$ etapa brasileira do estudo foram entrevistadas 2.128 mulheres de 15 a 49 anos que morassem no domicílio sorteado e tivessem capacidade física e mental para responderem a questionário em entrevista face a face. $\mathrm{O}$ questionário usado foi construído pela equipe da OMS que coordenou a realização da pesquisa, com a colaboração das equipes de pesquisadores responsáveis pela condução da coleta de dados nos países participantes do estudo.

Para os fins da referida pesquisa foram estabelecidas, como modalidades de violência relevantes, a violência física (VF) e a violência sexual (VS) praticadas por parceiro íntimo, definido como o companheiro ou ex-companheiro

${ }^{76}$ PREFEITURA DA CIDADE DE SÃO PAULO. Histórico Demográfico do Município de São Paulo: Introdução.

Disponível em: $<$ http://smdu.prefeitura.sp.gov.br/historico_demografico/introducao.php $>$. Acesso em 18.06.2011.

77 InSTITUTO BRASILEIRO DE GeOgRAFia E ESTATístiCA. População nos Censos Demográficos, segundo as Grandes Regiões e as Unidades da Federação - 1872/2010. Disponível em:

$<\mathrm{http} / / /$ www.ibge.gov.br/home/estatistica/populacao/censo2010/tabelas_pdf/Brasil_tab_1_4.pdf $\$$. Acesso em 18.06.2011. 
com os quais as mulheres viviam ou viveram, independentemente de união formal, incluindo os namorados atuais desde que com relacionamento sexual.

A ocorrência de violência contra a mulher foi considerada presente quando a entrevistada respondeu "sim" a pelo menos um dos itens de qualquer dos dois conjuntos de perguntas (seis itens para VF e três itens para VS).

As variáveis utilizadas no estudo foram assim compostas:

Bloco 1: Características sociodemográficas

1. Idade em anos completos: 15 a 19,20 a 29,30 a 39 e 40 a 49 ;

2. Anos completos de escolaridade: acima de 12, de 9 a 11 e de 0 a 8 ;

3. Situação conjugal: casada, união informal, namorando com relação sexual, separada, viúva ou sem parceiro;

4. Número de pessoas na casa por cômodo: $<2$ ou $>2$;

5. Ajuda sociocomunitária, compreendida a partir de cinco perguntas, com a atribuição de um ponto a cada um dos itens e classificação em "pouca ajuda" (0 a 1), "alguma ajuda" (de 2 a 4 pontos) e "muita ajuda" (5 pontos):

5.1. Conhecimento entre os moradores da comunidade em que mora a entrevistada;

5.2. Se os vizinhos fariam algo para apartar uma briga na rua com agressão física; 
5.3. Se as pessoas se dispõem a contribuir com tempo, trabalho ou dinheiro para os projetos comunitários;

5.4. Se as pessoas confiam em pedir e emprestar dinheiro;

5.5. Se os vizinhos ajudariam diante de um acidente ou doença na família dela.

6. Cor da pele auto-referida: branca, negra, parda, amarela e indígena.

Bloco 2: família de origem

1. A mãe era agredida fisicamente pelo parceiro: sim, não, pais separados ou não sabe;

2. Apoio familiar: contar ou não com parentes para the dar apoio em caso de problemas.

Bloco 3: experiências de autonomia/submissão relacionadas às questões de gênero

1. Violência sexual por outros que não o parceiro a partir dos 15 anos de idade: sim e não;

2. Abuso sexual antes dos 15 anos: sim e não à pergunta "antes dos 15 anos, você lembra se alguém em sua família tocou em você sexualmente ou obrigou-a a uma atividade sexual que você não queria?";

3. Número de gestações: nenhuma; de 1 a 2; de 3 a 4 ; 5 ou mais;

4. Problemas da mulher com a bebida, considerado "sim" quando houve resposta positiva a pelo menos um dos seguintes 
problemas quando relacionados ao consumo de álcool: problemas com dinheiro, saúde, conflitos familiares ou com amigos, problemas com autoridade nos últimos 12 meses;

5. Autonomia financeira, composta a partir das perguntas:

5.1. Com fonte de renda própria (sim e não);

5.2. Possuir bens, tais como casa, terras ou joias, próprios e compartilhados ou que sejam exclusivos do parceiro (sim e não). A mulher foi considerada com autonomia financeira quando tinha bens próprios e/ou fonte de renda própria;

6. Idade e consentimento da primeira relação sexual: forçada ou não queria e menor ou igual a 15 anos; forçada ou não queria e $>16$ anos; consensual e menor ou igual a 15 anos; consensual e $>16$ anos;

7. Aceitação da violência: "sim" quando resposta positiva ou "não sei" a pelo menos uma das seis opções à questão - o homem tem boas razões para bater em sua esposa se: ela não realiza o trabalho doméstico de forma satisfatória; ela o desobedece; ela se recusa a manter relações sexuais com ele; ela pergunta se ele tem outras namoradas; ele suspeita que ela é infiel; ele descobre que ela é infiel.

$\mathrm{Na}$ análise dos dados, a variável dependente foi a ocorrência de violência física e/ou sexual cometida por parceiro íntimo (VPI) ao menos uma vez na vida. Foram entrevistadas, respondendo de modo completo ao questionário, 940 mulheres em SP e 1.188 na ZMP (taxa de resposta de 89,9\% e 95,7\% respectivamente) que tiveram ao menos um parceiro íntimo na vida.

A pesquisa apurou que a prevalência de violência física e/ou sexual durante a vida foi de $28,9 \%$ em SP e de $36,9 \%$ na ZMP. Em SP, relativamente à ZMP, foi constatado de modo significativo mais mulheres com 30 anos ou mais, 
escolaridade secundária ou superior, namorando com relacionamento sexual, brancas, com autonomia financeira, e que sofreram violência sexual após os 15 anos por agressor não-parceiro. Por outro lado, na ZMP havia mais mulheres com muito apoio comunitário, que relataram agressão da mãe pelo companheiro, em união informal, cuja primeira relação ocorreu antes dos 15 anos, com mais de dois filhos e que concordam que o homem teria alguma razão para bater em sua parceira.

Nos seus modelos finais, SP e ZMP compartilharam quatro fatores associados à VPI: história de agressão da mãe por parceiro; abuso sexual na infância da entrevistada; cinco ou mais gestações e problemas com a bebida. Apenas para SP, identificaram-se como associados à VPI os seguintes fatores: ser separada, viúva ou sem parceiro e ter entre uma e quatro gestações. Na ZMP, isoladamente, mostraram-se associados à VPI: viver junto; ter primeira relação sexual antes 15 anos, forçada ou não.

Outros estudos conduzidos no Brasil, entretanto, por vezes apresentaram resultados diversos. Os pesquisadores da USP-RP Elisabeth Meloni Vieira, Gleici da Silva Castro Perdona e Manoel Antonio dos Santos conduziram estudo $^{78}$ com 504 mulheres de 15 a 49 anos, usuárias de cinco unidades básicas e distritais de saúde (UBDS) em Ribeirão Preto/SP, de 11 de agosto a 8 de dezembro de 2008, no qual a prevalência de VPI encontrada foi de 34,5\%. O referido estudo utilizou-se de algumas das variáveis do estudo WHO VAW Study, mas levou em conta variáveis como o uso de drogas pelo parceiro íntimo, por exemplo, bem como não abordou a ocorrência de violência sexual.

Já estudo ${ }^{79}$ desenvolvido em 2007 na comunidade do Varjão, na região metropolitana de Brasília/DF, pelos pesquisadores da UnB Leides Barroso Azevedo Moura, Lenora Gandolfi, Ana Maria Nogales Vasconcelos e Riccardo Pratesi encontrou uma prevalência de VF de $58,6 \%$ ao longo da vida e de $32,4 \%$ no

\footnotetext{
${ }^{78}$ Publicado em VIEIRA, Elisabeth Meloni; PERDONA, Gleici da Silva Castro; SANTOS, Manoel Antonio dos. Fatores associados à violência física por parceiro íntimo em usuárias de serviços de saúde. Revista de Saúde Pública, São Paulo, v. 45, n. 4, ago. 2011, p. 730-737.

${ }^{79}$ Publicado em MOURA, Leides Barroso Azevedo et al . Violências contra mulheres por parceiro íntimo em área urbana economicamente vulnerável, Brasília, DF. Revista de Saúde Pública, São Paulo, v. 43, n. 6, dez. 2009, p. 944-953.
} 
último ano e uma prevalência de VS de $28,8 \%$ ao longo da vida e de $15,5 \%$ no último ano. Aqui, ao contrário de estudos anteriores, houve a preocupação na aferição de casos de violência contra a mulher no espaço de 12 meses a contar das entrevistas, enquanto os demais buscaram constatar ocorrências ao longo de toda a vida das entrevistadas.

Essa oscilação nos resultados, frise-se, não é uma particularidade brasileira. Mesmo as pesquisas feitas em outros países tendem a divergir entre si quanto às variáveis em análise e à delimitação do campo a ser pesquisado, o que contribui para que os resultados sejam vistos com certa desconfiança, em especial por leigos, quando confrontadas diversas pesquisas entre si.

O que se observa, entretanto, é que as pesquisas empíricas sobre violência doméstica contra a mulher acabam por se distanciar de referenciais médico-legais no momento da definição das variáveis a serem estudadas, o que acaba por tornar difícil a comparação dos resultados com aqueles obtidos em outras pesquisas feitas com dados colhidos segundo os padrões médico-legais, tais como as ocorrências registradas pelos Institutos Médico-Legais a partir de comunicações de crimes feitas nas DEAMs.

As pesquisas voltadas à apuração de ocorrências de violência contra a mulher ao longo da vida, embora úteis para se constatar em que medida o problema se encontra mais ou menos disseminado em determinadas comunidades, não fornecem dados suficientes para se constatar, por exemplo, de que forma os casos de violência contra a mulher aumentam ou diminuem numa dada localidade.

Da mesma forma, tais estudos não permitem a comparação entre o número de casos declarados pelas entrevistadas em um determinado período e aquele apurado pelas DEAMs em igual período - comparação essa que permitiria, por exemplo, estimar a dimensão da "cifra negra" decorrente da subnotificação pelas vítimas. 
É certo, ainda, que as pesquisas nem sempre fornecem subsídios detalhados sobre eventuais lesões corporais decorrentes da violência doméstica contra a mulher, uma vez que a expressão "violência física" é demasiadamente ampla, abrangendo qualquer forma de interação física contra o corpo da vítima, sem correlação direta com a ocorrência de lesões corporais.

No que diz respeito especificamente às lesões corporais é de se propor, portanto, a realização de pesquisas voltadas à apuração de casos de violência física contra a mulher num período de 12 meses a contar da aplicação dos questionários na amostra selecionada, com a utilização de critérios médico-legais para se definir a distribuição proporcional das ocorrências de acordo, por exemplo, com a natureza da lesão corporal sofrida pela entrevistada (leve, grave e gravíssima), as sequelas sofridas pela vítima (incapacidade para as ocupações habituais, por mais de trinta dias; perigo de vida; debilidade permanente de membro, sentido ou função; aceleração de parto; incapacidade permanente para o trabalho; enfermidade incuravel; perda ou inutilização do membro, sentido ou função; deformidade permanente; aborto) e a intenção do agressor (dolo ou culpa), entre outros, o que permitirá uma maior interação desses resultados com aqueles apurados pelo sistema de Justiça.

7.3. O âmbito de proteção da Lei 11.340/06 e a identificação médico-legal do sexo

Outra contribuição importante da Medicina Legal para a compreensão e enfrentamento da violência contra a mulher reside no fornecimento de informações a respeito das possíveis vítimas, a fim de se identificá-las ou não como sujeitas aos instrumentos de tutela previstos na Lei $n^{\circ} 11.340 / 06$.

Isso porque a referida Lei, embora disponha sobre a criação de mecanismos para coibir e prevenir a violência doméstica e familiar contra a mulher, não traz uma definição do que se entende por mulher para os fins ali previstos. 
Com efeito, a Lei $\mathrm{n}^{\mathrm{o}} 11.340 / 06$ aponta entre seus fundamentos o art. 226, $\S 8^{\circ}$, da Constituição Federal, a Convenção sobre a Eliminação de Todas as Formas de Discriminação contra as Mulheres e a Convenção Interamericana para Prevenir, Punir e Erradicar a Violência contra a Mulher diplomas esses os quais, frise-se, também não fornecem ao operador do Direito critérios de definição do que se entende por mulher para fins de proteção contra práticas violentas.

O legislador teve a preocupação apenas em fazer referência expressa à orientação sexual da mulher, que pode ser de natureza heterossexual ou homossexual, como elemento que não pode ser invocado a fim de afastar a incidência das medidas de tutela e proteção previstas na Lei $n^{\circ} 11.340 / 06$, conforme se observa no art. $2^{\circ}$ :

Art. $2^{\circ}$. Toda mulher, independentemente de classe, raça, etnia, orientação sexual, renda, cultura, nível educacional, idade e religião, goza dos direitos fundamentais inerentes à pessoa humana, sendo-lhe asseguradas as oportunidades e facilidades para viver sem violência, preservar sua saúde fisica e mental e seu aperfeiçoamento moral, intelectual e social.

O que se há de ter em mente, para fins de abordagem médicolegal dessa questão, é que na sociedade ocidental a definição social de gênero encontra substrato em características biopsicológicas próprias dos indivíduos, as quais se integram para a formação do sexo.

Nesse sentido, Odon Ramos Maranhão ${ }^{80}$ observa que “o sexo resulta do equilíbrio de diferentes fatores que agem de forma concorrente nos planos físico, psicológico e social, e da integração desses fatores decorrem as implicações jurídicas".

\footnotetext{
${ }^{80}$ In Manual de sexologia médico-legal. São Paulo: RT, 1972, p. 2.
} 
Claudio Cohen ${ }^{81}$ aponta que, de acordo com Bronislaw Malinowski, a reprodução constitui uma das necessidades básicas do homem. A resposta cultural a essa necessidade se estabelece através do comportamento sexual, que pode variar nas diversas sociedades. Na sociedade ocidental a diferenciação entre os sexos se daria, portanto, com base na avaliação da contribuição que cada indivíduo pode oferecer ao processo reprodutivo.

Tanto é assim que em diversas definições de sexo o contexto reprodutivo é invocado como elemento de diferenciação. Matilde Josefina Sutter ${ }^{82}$ apresenta algumas definições por si encontradas em dicionários que vão nesse sentido: "conformação particular que distingue o homem da mulher, atribuindo-lhes um papel determinado na reprodução"; "condição orgânica que distingue o macho da fêmea"; "condição de um organismo que se manifesta pela produção de ovos, nas fêmeas, ou de espermatozóides, nos machos, ou ainda tanto de ovos como de espermatozoides em certos invertebrados hermafroditas”.

Em igual sentido, Marilyn Strathern $^{83}$ enfatiza que no contexto do que identifica como sendo o "sistema de parentesco euro-americano" os fatos considerados naturais da procriação seriam a relação sexual, a transmissão dos genes e o parto.

Assim, segundo a autora a construção do gênero se torna relevante no sistema euro-americano como marcador da diferença a partir do sexo: homens e mulheres se distinguem e se comparam em termos do que podem trazer para um relacionamento, em especial no contexto da procriação.

Se os relacionamentos se baseiam na comparação de pessoas nos relacionamentos procriativos a comparação por gênero torna se concreta e evidente pelo papel de cada indivíduo no intercurso sexual.

\footnotetext{
${ }^{81}$ In Compêndio de Medicina Legal. 2a ${ }^{\text {a }}$ Ed.. São Paulo: Saraiva, 1992, p. 285.

${ }^{82}$ In Determinação e mudança de sexo: aspectos médico-legais. São Paulo: RT, 1993, p. 28.

83 "Necessidade de pais, necessidade de mães". Estudos Feministas. V. 3, n. 2. Florianópolis: UFSC, 1995, p. 313.
} 
Com isso a autora conclui que nem mesmo avanços técnicos como a reprodução assistida, a qual prescinde da presença física do homem, não se mostra capaz de separar procriação de relações de gênero no sistema euro-americano.

Evidente, porém, que atividades sexuais outras que não aquelas que visam a necessidade reprodutiva da espécie humana são realizadas pelo homem em nossa sociedade, e tais atividades não são irrelevantes ao Direito.

Tanto é assim, como já visto, que o legislador teve o cuidado de estender à mulher homossexual vítima de violência doméstica as mesmas condições de tutela usufruídas pela mulher heterossexual.

A questão que se coloca, pois, é saber em que medida outros indivíduos que não sejam considerados mulheres do ponto de vista puramente biológico podem ser protegidos pela Lei $n^{0} 11.340 / 06$, a qual aparentemente se destinaria exclusivamente à tutela da mulher.

Para Matilde Josefina Sutter ${ }^{84}$ a determinação da sexualidade decorre da conjunção de dois grupos de fatores: os biológicos, compostos pelas características genotípicas, endócrino-gonadais e morfológicas do indivíduo, e os psicológicos, compostos pelas reações do indivíduo a determinados estímulos.

Ainda segundo a autora, a identificação do indivíduo com um determinado sexo se dá de acordo com a interação desses fatores num determinado ambiente:

(...) o sexo genético, o endócrino e o morfológico, devidamente integrados, permitem que se considere um individuo, biologicamente, como pertencente ao sexo masculino ou ao feminino. Sua sanidade fará presumir sua funcionalidade sexual. Como todos esses elementos nesta hipótese não apresentam se não uma orientação sexual, à primeira vista pode-se deduzir que suas

\footnotetext{
${ }^{84}$ In Determinação e mudança de sexo: aspectos médico-legais, p. 30.
} 
reações psicológicas correspondam ao seu sexo biológico. Isto implicaria também em se considerar que seu impulso sexual, sua libido, se volte para pessoas do sexo oposto ao seu, pois esta reação é a esperada, quando inexiste qualquer desvio, biopsicomorfo genético.

A definição do sexo para fins jurídicos, ainda segundo a autora $^{85}$, corresponde necessariamente ao sexo biológico, vez que no momento do nascimento não há como se formar juízo a respeito do sexo psicológico, o qual se manifestará posteriormente com o desenvolvimento do indivíduo e poderá divergir, em maior ou menor medida, do sexo biológico:

O sexo jurídico é um estado da pessoa, inscrito no Registro Civil e é, salvo erro, imutável. Corresponderá, portanto, ao sexo biológico, uma vez que em idade precoce não caberia a elaboração de um perfil psicológico. Nossa legislação não faculta ao individuo a possibilidade de escolher o sexo, por se tratar de um direito atualmente indisponivel. (...)

Entretanto, com o passar do tempo, o indivíduo poderá, de diferentes formas, revelar que a suposta sintonia entre seus diversos fatores determinantes da sexualidade é na realidade discutivel.

Dentre o que chama de tipos sexuais anômalos, a autora elenca as seguintes categorias:

a) Intersexuado: indivíduo cujos fatores biológicos determinantes do sexo não são harmônicos entre si.

O sexo jurídico do intersexuado deve ser o dominante biologicamente e que lhe confere funcionalidade sexual. Contudo, numa verificação tardia de erro, admite-se a livre escolha do intersexuado, em razão das dificuldades já enfrentadas para se identificar.

${ }^{85}$ Op. cit., p. 30/31. 
b) Transexual: indivíduo que rejeita seu sexo biológico, identificando-se com o sexo oposto, ao qual obsessivamente deseja permanecer.

O transexual, segundo a autora, rejeita qualquer tentativa de recondução ao seu sexo biológico, almejando a transformação da genitália, bem como a redesignação do sexo.

c) Homossexual: indivíduo que, identificando-se com o seu sexo biológico, mantém relações sexuais com parceiro do mesmo sexo, ainda que ocasionalmente.

Em relação aos homossexuais Claudio Cohen ${ }^{86}$ ressalva que a seu ver, nesse caso, ocorre a aceitação do sexo morfológico a despeito da divergência com o sexo psicológico, ao contrário do que ocorre com o transexual: a genitália do homossexual lhe é satisfatória como fonte de gratificação sexual, ainda que diversa de sua identidade sexual no plano psíquico.

d) Travesti: indivíduo que aceita seu sexo biológico mas depende do uso de roupagem cruzada para obter excitação sexual.

Em relação às mulheres, como já visto, o fator determinante para a incidência da Lei 11.340/06 é o sexo biológico, uma vez que o legislador estendeu os mecanismos de proteção ali previstos a todas as mulheres independentemente de orientação sexual, sem grandes margens para interpretação.

E em relação aos tipos sexuais anômalos, seria possível estender-lhes a incidência da referida lei com base em outros fatores? Rogério Sanches Cunha e Ronaldo Batista Pinto ${ }^{87}$ apontam a existência de duas correntes sobre o tema:

\footnotetext{
86 "Sexologia", in Compêndio de Medicina Legal, p. 295.

${ }^{87}$ In Violência Doméstica: Lei Maria da Penha (Lei 11.340/2006) comentada artigo por artigo. $3^{\mathrm{a}}$ ed., São Paulo: RT, 2011, p. 32.
} 
Em eventual resposta à indagação inicial podem ser observadas duas posições: uma primeira, conservadora, entendendo que o transexual, geneticamente, não é mulher (apenas passa a ter órgão genital de conformidade feminina), e que, portanto, descarta, para a hipótese, a proteção especial; já para uma corrente mais moderna, desde que a pessoa portadora de transexualismo transmute suas características sexuais (por cirurgia e modo irreversivel), deve ser encarada de acordo com sua nova realidade morfológica, eis que a jurisprudência admite, inclusive, retificação de registro civil.

A nosso ver a resposta passa, necessariamente, por uma leitura da Lei 11.340/06 à luz do art. 1º III, da Constituição Federal.

Com efeito, como já visto anteriormente, o referido dispositivo estabelece que um dos fundamentos da República Federativa do Brasil é a dignidade da pessoa humana, a qual compreende, de acordo com Luis Roberto Barroso e Ana Paula de Barcelos ${ }^{88}$ :

(...) um espaço de integridade moral a ser assegurado a todas as pessoas por sua só existência no mundo. É um respeito à criação, independentemente da crença que se professe quanto à sua origem. A dignidade relaciona-se tanto com a liberdade e valores do espírito como com as condições materiais de subsistência.

Á luz do referido princípio parece evidente que a identificação psicológica do indivíduo com um determinado sexo, ainda que em dissonância com seu sexo biológico, é elemento indissociável de seu espírito e de sua personalidade, repercutindo no papel social por si assumido em sociedade.

Por essa razão, a identidade sexual feminina psicologicamente aceita por indivíduo biologicamente masculino com indissociável

${ }^{88}$ In "O começo da história: a nova interpretação constitucional e o papel dos princípios no direito brasileiro". Revista Interesse Público. no 19, v. 5, 2003, p. 65. 
de sua condição de pessoa não pode ser negligenciada no momento da aplicação da Lei $\mathrm{n}^{\mathrm{o}} 11.340 / 06$.

Limitar a extensão da Lei a casos nos quais se observa a prévia transformação cirúrgica da genitália da vítima, a nosso ver, não se coaduna com a importância do fator psicológico na determinação do sexo, e portanto da condição de pessoa.

Nesse sentido, Matilde Josefina Sutter $^{89}$ aponta como a sexualidade definida no plano psicológico é essencial à construção da personalidade:

Atualmente. a sexualidade não é mais encarada apenas como manifestação da libido, voltada para a atividade sexual propriamente dita, mas sim de uma maneira mais ampla, permeando diversos aspectos do fisico, personalidade $e$ comportamento do indivíduo. Algumas dessas características podem passar despercebidas, ou não serem devidamente compreendidas como tendo um cunho sexual, caso não sejam bem observadas. Dai a necessidade de um estudo muito cuidadoso, nos casos em que se faça necessária a definição do sexo da pessoa, do ponto de vista médico, com implicações legais.

A sexualidade desabrocha através de fantasias, admitidas ou não, e de desejos e identificações, desde os nitidamente sexuais, até os que aparentemente não têm nenhuma relação com sexo, como escolha da profissão, passando pelos símbolos sociais de seu sexo, como roupa e cabelos. Com a mudança de costumes, tanto no campo profissional, como no de vestimentas, tornou-se possivel. para as pessoas com problemas de identidade sexual, adotar atitudes e atividades antes reservadas ao sexo oposto. Antigamente, as pressões sociais impediriam a realização do desejo de vestir-se e comportar-se como pessoa do sexo oposto ao seu e, possivelmente, inibiriam até mesmo que tal desejo aflorasse ao nivel do consciente. Hoje em dia, persistem as expectativas familiares e sociais, mas sua pressão já não se faz sentir de

${ }^{89}$ In Determinação e mudança de sexo: aspectos médico-legais, p. 24/25. 
maneira tão forte. As características individuais de personalidade também influirão na descoberta precoce ou tardia das tendências sexuais. Algumas crianças, recebendo maiores estímulos, poderão dar vazão a fantasias sexuais. Outras, devido a um temperamento acentuadamente introvertido, ou ainda a uma educação pouco liberal, descobrem tardiamente as reações do seu próprio corpo. Dos deficientes aos superdotados, pode ser observada uma variada gama de comportamentos sexuais, cuja relevância vai além da reprodução e da identificação do individuo no seu meio social, e que são estudados nas áreas psicológica, médica e jurídica.

Muito antes de uma mulher ou de um homem se unirem sexualmente, sonharam com isso e desejaram tal situação. Da mesma forma, antes que um individuo biologicamente masculino busque orientação médica, pedindo que sejam alterados seus genitais, de forma que se pareçam com os de uma mulher, ele se vestiu de maneira feminina, encontrando satisfação nisso. Ele também desejou exercer e, algumas vezes chegou a consegui-lo, uma profissão tida como exclusivamente feminina e, em todas as suas opções, escolheu ou foi levado a ter atitudes que, somadas, só não causariam surpresa se partissem de uma mulher. $O$ comportamento desses indivíduos, quando comparado com o de mulheres em geral, em observações feitas por estudiosos do assunto, demonstrou ser mais feminino que o delas. Isso se explica pelo fato de que pessoas seguras de sua identidade sexual podem se permitir ocasionais gestos ou atitudes costumeiros do sexo oposto, pois estão certas de sua identidade sexual, e essas atitudes não abalam a consciência que têm da mesma. Por outro lado, também não necessitam constantemente provar aos outros ou reafirmar a si mesmos aquilo que são, biológica $e$ psicologicamente.

Vale frisar que de acordo com a jurisprudência dos Tribunais Superiores brasileiros "a dignidade da pessoa humana, um dos fundamentos do 
Estado democrático de direito, ilumina a interpretação da lei ordinária ${ }^{90 ",}$, a reforçar a interpretação ora proposta em favor daqueles cuja identidade sexual é feminina, independentemente do sexo biológico.

Nesse sentido, Maria Berenice Dias reconhece a possiblidade de extensão, embora enfocando a relevância social da identidade feminina, ao invés da médico-legal:

Lésbicas, transexuais, travestis e transgêneros, que tenham identidade social com o sexo feminino estão ao abrigo da Lei Maria da Penha. A agressão contra elas no âmbito familiar constitui violência doméstica. Ainda que parte da doutrina encontre dificuldade em conceder-lhes o abrigo da Lei, descabe deixar à margem da proteção legal aqueles que se reconhecem como mulher. ${ }^{91}$

Em idêntico sentido, há precedentes judiciais admitindo a incidência da Lei $\mathrm{n}^{\mathrm{o}}$ 11.340/06 em situações nas quais a vítima não é mulher do ponto de vista biológico, mas se identifica como tal psicologicamente, a saber;

Conflito negativo de competência. Violência doméstica e familiar. Homologação de auto de prisão em flagrante. Agressões praticadas pelo companheiro contra pessoa civilmente identíficada como sendo do sexo masculino. Vítima submetida à cirurgia de adequação de sexo por ser hermafrodita. Adoção do sexo feminino. Presença de órgãos reprodutores femininos que the conferem a condição de mulher. Retificação do registro civil já requerida judicialmente. Possibilidade de aplicação, no caso concreto, da Lei n. 11.340/06. Competência do juizo suscitante. Conflito improcedente." (TJSC, 3." C.Crim., CJ 2009.006461-6,j. 14.08.2009, rel. Des. Roberto Lucas Pacheco)

\footnotetext{
${ }^{90}$ STJ, HC 9.892-RJ, DJ 26.3.01, Rel. orig. Min. Hamilton Carvalhido, Rel. para ac. Min. Fontes de Alencar. Citado por BARROSO, Luis Roberto e BARCELOS, Ana Paula de., op. cit., p. 41.

${ }^{91}$ In A Lei Maria da Penha na Justiça: a efetividade da Lei 11.340/2006 de combate à violência doméstica e familiar contra a mulher. $2^{\mathrm{a}}$. ed., São Paulo: RT, 2010, p. 58.
} 
Para a configuração da violência doméstica não é necessário que as partes sejam marido e mulher, nem que estejam ou tenham sido casados, já que a união estável também se encontra sob o manto protetivo da lei. Admite-se que o sujeito ativo seja tanto homem quanto mulher, bastando a existência de relação familiar ou de afetividade, não importando o gênero do agressor, já que a norma visa tão somente à repressão e prevenção da violência doméstica contra a mulher. Quanto ao sujeito passivo abarcado pela lei, exige-se uma qualidade especial: ser mulher, compreendidas como tal as lésbicas, os transgêneros, as transexuais e as travestis, que tenham identidade com o sexo feminino. Ademais, não só as esposas, companheiras, namoradas ou amantes estão no ãmbito de abrangência do delito de violência doméstica como sujeitos passivos. Também as filhas e netas do agressor como sua mãe, sogra, avó ou qualquer outra parente que mantém vínculo familiar com ele podem integrar o polo passivo da ação delituosa (TJMG, HC 1.0000.09.513119-9/000, rel. Júlio Cezar Gutierrez, j. 24.02.2010).

Não há falar, aqui, em analogia in malam partem em matéria penal quando se propõe a extensão da Lei $\mathrm{n}^{\mathrm{o}}$ 11.340/06 em favor de indivíduos psicologicamente identificados com o sexo feminino, uma vez que se trata de medida apta a ampliar a tutela de direitos fundamentais, em especial a dignidade da pessoa humana, de acordo com a Constituição Federal e os instrumentos internacionais assinados pelo Brasil que têm relação à questão da violência contra a mulher.

Vale destacar, nesse sentido, que o art. $4^{\circ}$ da Lei prevê expressamente a possibilidade de interpretação conforme os fins sociais aos quais o diploma se destina, o que abrange a otimização da tutela de direitos fundamentais:

Art. $4^{\circ}$. Na interpretação desta Lei, serão considerados os fins sociais a que ela se destina e, especialmente, as condições peculiares das mulheres em situação de violência doméstica e familiar. 
A respeito do referido dispositivo, Rogério Sanches Cunha e Ronaldo Batista Pinto ${ }^{92}$ afirmam se tratar de autorização legal para a interpretação sociológica da Lei:

Ao ressaltar que o intérprete da lei deve levar em conta os fins sociais, o legislador tomou de empréstimo ideia contida na Lei de Introdução às Normas do Direito Brasileiro (Dec.-Iei 4.657/42), que em seu art. $5^{\circ}$ dispõe que "na aplicação da lei, o juiz atenderá aos fins sociais a que ela se dirige (...)".

Trata-se da chamada interpretação sociológica, cujo método se baseia na adaptação do sentido da lei às realidades sociais, cabendo ao intérprete acompanhar as mudanças que o cercam, os impactos que tais alterações causam na sociedade, enfim, conferir à norma um significado que a insira no contexto em que concebida.

\section{(...)}

Não que se pretenda, com isso, negar a importância da chamada interpretação gramatical ou filológica, que toma por base o significado da palavra contida na lei ou sua função gramatical. Tem ela sua relevância e se constitui, mesmo, no primeiro passo para a interpretação da lei. Mas não é suficiente. De sorte que, a simples análise do alcance da palavra, insulada do contexto em que foi produzida, sem se atentar ao espirito da norma, induz a uma interpretação defeituosa, fincada na velha afirmação de que o texto claro prescinde de interpretação, sintetizada no brocardo latino segundo o qual in claris cessat interpretatio.

Foi longe o tempo em que, por ilusão, se entendia que o legislador tudo podia prever e, com isso, ao juiz nada mais restava senão, como verdadeiro matemático, aplicar a lei. O Código da Baviera, de 1812, chegava a proibir o juiz de interpretar a lei. À época do

${ }^{92}$ In Violência Doméstica: Lei Maria da Penha (Lei 11.340/2006) comentada artigo por artigo. $3^{\text {a }}$ ed., São Paulo: RT, 2011, p. 41/42. 
Código de Napoleão, o civilista não ensinava o direito civil a seus alunos, mas sim o Código. Aliás, o direito civil era o próprio Code.

Essa falsa impressão, atualmente, não mais sobrevive, cabendo ao intérprete, assim, adequar a norma aos dias em que vive. Preso a valores éticos ou religiosos, incorreria em enorme equívoco o juiz que, por exemplo, deixasse de reconhecer, nos tempos modernos, a existência de relacionamentos homossexuais a exigirem a proteção da lei. Eles sempre existiram. Mas a necessidade de sua tutela, hoje, é muito maior do que era há cinquenta anos, em face do surgimento de novos direitos, novas relações e novas realidades inconcebiveis àquela época.

É com esse espírito, desarmado, despido de preconceitos, livre de fetichismos e atento à realidade que o cerca, que deve o intérprete, em nosso entendimento, enfrentar os desafios propostos pela lei.

O reconhecimento dessa identidade sexual feminina, entretanto, a nosso ver depende de constatação médico-legal, sob pena de se admitir que a mera declaração de vontade do indivíduo determine a incidência de dispositivos de proteção e tutela em seu benefício ao mesmo tempo em que sujeita o agente a estatuto legal menos favorável.

A vítima de violência que se encontra psicológica e funcionalmente inserida num contexto de gênero no qual assume o papel feminino deverá ser avaliada por profissional habilitado (médico, psicólogo, etc.) a fim de que se reconheça o seu enquadramento na Lei $n^{0} 11.340 / 06$ para fins de proteção e tutela.

A supressão da avaliação médico-legal, nesses casos, somente se faria admissível mediante realização de inspeção judicial, definida por Eduardo Roberto Alcântara Del_Campo como "uma forma de vistoria feita pelo 
próprio juiz para verificação de um determinado fato relacionado com a lide",93, em homenagem ao princípio judex peritum peritorum.

7.4. As formas de violência contra a mulher e sua apuração médico-legal

Além das contribuições já mencionadas, a Medicina Legal se mostra de curial importância em relação à constatação, no caso concreto, da modalidade de violência a qual a mulher foi submetida.

Isso porque, a despeito do legislador aparentemente ter reduzido a violência contra a mulher à ocorrência de lesões corporais - as quais são objeto de avaliação médico-legal independentemente da previsão em lei específica é certo que o art. $7^{\circ}$ da Lei $n^{\circ} 11.340 / 06$, já mencionado, estabelece que a violência contra a mulher se dá não só em termos físicos, mas também em termos psicológicos, sexuais, patrimoniais e morais.

Como já visto anteriormente, é a incidência da agravante contida no art. 61, II, "f" do CP aos casos de lesões corporais praticadas contra a mulher o fator determinante para se considerar a ocorrência de violência doméstica contra a mulher.

Assim, salvo melhor juízo, é de se afirmar que tanto as lesões efetivamente sofridas pela vítima quanto o contexto no qual aquelas foram inflingidas pelo agente apresentam relevância jurídica: aquela, para determinar a aplicação do art. 129, $\S \S 9$ e 10, conforme a intensidade da lesão; este último, para determinar a incidência da agravante.

Uma vez estabelecida essa relevância jurídica, temos que o contexto de violência no qual se deu o cometimento das lesões corporais contra a vítima mulher é parte integrante do corpo de delito, definido por Rogério Lauria

\footnotetext{
${ }^{93}$ In Exame e levantamento técnico pericial de locais de interesse à justiça criminal: abordagem descritiva e crítica. Dissertação de mestrado. Faculdade de Direito da USP, 2008, p. 26.
} 
Tucci como "o conjunto de todos os elementos sensíveis integrantes do fato criminoso",94.

A respeito do corpo de delito e da necessidade de seu exame, afirma Eduardo Roberto Alcântara Del-Campo:

Algumas infrações penais deixam vestígios (delita facti permanentis) e outras não (delita facti transeuntis).

Crimes como a injúria verbal (art. 140 do CP) ou o desacato (art. 331 do (P), nada deixam de material que possa ser analisado e consubstanciado em um trabalho pericial, devendo ser constatados por outros meios de prova.

Todavia, delitos, como o homicídio (art. 121 do CP) ou a maioria dos crimes patrimoniais, provocam modificações sensiveis no mundo real que podem ser percebidas por nossos sentidos ou por aparelhos especiais. Nesses casos é necessária a realização do exame de corpo de delito, cujo resultado será posteriormente apresentado sob a forma de relatório pericial. ${ }^{95}$

Em sentido idêntico temos a definição de José Lopes Zarzuela, citado por Del-Campo, por para quem o corpo de delito corresponde à:

“(...) somatória de elementos vestigiais encontradiços nos locais de fato, nos instrumentos relacionados com a prática de uma infração penal, no exame das peças ou na pessoa física, viva ou morta, deixados pelo sujeito ativo da infração penal, que serão apreciados, interpretados e descritos em laudo pericial","

\footnotetext{
${ }^{94}$ In Do corpo de delito no direito processual penal brasileiro. São Paulo: Saraiva, 1978, p. 68.

${ }^{95}$ In Exame e levantamento técnico pericial de locais de interesse à justiça criminal: abordagem descritiva e crítica. Dissertação de mestrado. Faculdade de Direito da USP, 2008, p. 29.

${ }^{96}$ Op. cit., p. 30.
} 
Desse modo, ao se analisar o rol de modalidades de violência contra a mulher estabelecido pelo legislador no art. $7^{\circ}$ da Lei 11.340/06 é de se reconhecer que todas são passíveis de constatação pelos sentidos, das quais três - a física, a psicológica e a sexual - apresentam evidente relevância médico-legal e devem ser objeto de exame de corpo de delito, malgrado a prática do sistema de Justiça limite o alcance do referido exame às lesões corporais sofridas pela vítima. As ocorrências de violência patrimonial e moral, por sua vez, são passíveis de apuração pericial com base em outros ramos do conhecimento.

Por fim, de acordo com Eduardo Roberto Alcântara DelCampo $^{97}$ outra modalidade de documento voltado à apuração médico-legal em sede de violência doméstica contra a mulher, embora sem a natureza de perícia, é a notificação compulsória prevista no art. $1^{\circ}$ da Lei $n^{\circ} 10.778 / 03$. Esse documento médico-legal se mostra de importância para a apuração do número de atendimentos de mulheres vítimas de violência doméstica pelos estabelecimentos da rede pública e privada de saúde, sendo que muitos desses atendimentos não se traduzem, necessariamente, em comunicações formais às DEAMs.

\footnotetext{
${ }^{97}$ In Exame e levantamento técnico pericial de locais de interesse à justiça criminal: abordagem descritiva e crítica. Dissertação de mestrado. Faculdade de Direito da USP, 2008, p. 65/67.
} 


\section{CONCLUSÕES}

Por todo o exposto neste trabalho, é possível concluir que a violência é parte indissociável da existência humana, em particular da vida em sociedade, uma vez que ela se faz presente tanto na formação do Estado e na sua relação com os indivíduos quanto nas relações cotidianas entre estes.

Embora presente, nem sempre a violência se faz visível. Exemplo disso se encontra nas relações de gênero, as quais se traduzem em diversos momentos de exercício da vontade do homem, por meios físicos, morais ou de outra natureza, em desfavor da vontade e da autonomia da mulher.

A violência contida nas relações de gênero, cuja percepção nem sempre se faz evidente na esfera pública, encontra nas relações domésticas um ambiente propício ao seu desenvolvimento longe dos olhos da sociedade, alheia à observância das normas jurídicas e dos Direitos Humanos. A violência doméstica contra a mulher surge, portanto, como subproduto perverso da violência de gênero.

Essa invisibilidade da violência doméstica contra a mulher, embora tenha atrasado a sua inclusão na pauta de preocupações com os Direitos Humanos, não foi suficiente para mantê-la à margem desse processo de afirmação dos Direitos Humanos permanentemente.

Diante da inércia dos Estados em enfrentar o problema é o movimento feminista que acaba por forçar a discussão da violência contra a mulher, em particular a ocorrida em contexto doméstico, a qual se traduz na definição da violência contra a mulher como ofensiva aos Direitos Humanos.

Nesse sentido há o estabelecimento, na esfera internacional, de documentos que dispõem expressamente sobre a erradicação da violência contra a mulher como meta a ser alcançada, prevendo obrigações nesse sentido aos Estados signatários. 
O Brasil se vê inserido nesse movimento de enfrentamento à violência contra a mulher como signatário da Convenção sobre a Eliminação de Todas as Formas de Discriminação contra a Mulher (1979) e da Convenção Interamericana para Prevenir, Punir e Erradicar a Violência contra a Mulher (1994).

A adesão a tais diplomas, entretanto, não foi suficiente para que a violência contra a mulher, em especial a doméstica, fosse enfrentada com seriedade pelo legislador, com a edição de diplomas esparsos que não encaravam a questão de modo sistemático.

Foi somente após a denúncia do caso Maria da Penha perante a CIDH da OEA, na qual se apresentou àquele órgão um quadro inaceitável de inércia dos órgãos públicos brasileiros, notadamente o Judiciário cearense, diante de reiteradas tentativas de homicídio contra a farmacêutica Maria da Penha Maia Fernandes por parte de seu esposo, é que houve a edição da Lei 11.340/06, especificamente voltada à criação de mecanismos para coibir a violência doméstica e familiar contra a mulher.

Embora estabeleça um modelo baseado em três formas de atuação para o enfrentamento do problema (preventiva, psicossocial e punitiva), a Lei 11.340/06 se mostrou tímida em matéria de tipificação penal, estabelecendo apenas uma nova redação à agravante genérica do art. 61, II, “f” e ao $\S 9^{\circ}$ do art. 129 do CP, bem como incluindo o $\S 11$ no referido art. 129.

O modelo de intervenção jurídico-penal a respeito da violência contra a mulher é subsidiário em face da tutela da integridade física, sem levar em conta as particularidades das práticas violentas contra a mulher, notadamente as ocorridas em contexto doméstico: é da interpretação sistemática do art. 61, II, "f" e do art. 129 do CP com outros dispositivos da Lei 11.340/06 que se identifica a especialidade da violência doméstica contra a mulher em face de outras práticas delitivas.

Diante desse quadro, é de se observar que a Medicina Legal tem contribuições positivas à compreensão e enfrentamento da violência doméstica 
contra a mulher, ainda mais quando o legislador estabelece o crime de lesões corporais como núcleo estruturante da referida tutela penal.

É por meio do emprego de instrumentos e critérios médicolegais, por exemplo, que se pode obter a adequada mensuração dos casos de lesões corporais decorrentes de violência doméstica contra a mulher, bem como avaliar em que medida a incidência da lei 11.340/06 pode ser estendida a indivíduos que não correspondem, biologicamente, ao sexo feminino e constatar a ocorrência das múltiplas possibilidades de violência contra a mulher elencadas pelo legislador no art. $7^{\circ}$ da referida lei.

O que se vê, enfim, é que a violência doméstica contra a mulher não só pode, mas deve constituir objeto de preocupação da Medicina Legal, bem como as contribuições da Medicina Legal podem e devem ser levadas em consideração tanto na formulação das políticas públicas de prevenção e repressão à violência doméstica contra a mulher quanto na prática dos sistemas de Justiça e de Saúde Pública. 


\section{REFERÊNCIAS BIBLIOGRÁFICAS}

AGÊNCIA PATRICIA GALVÃO. Organizações de defesa dos direitos das mulheres.

Disponível

em:

$<$ http://www.agenciapatriciagalvao.org.br/index.php?option=com_content\&view=art icle\&id $=94 \&$ catid $=103>$. Acesso em 02.01.2012.

ALAGOAS. Secretaria de Estado da Mulher, da Cidadania e dos Direitos Humanos. Disponível em: <http://www.mulherecidadania.al.gov.br/. Acesso em 02.10.2012.

ALCÂNTARA, H. R. de. Perícia médica judicial. Rio de Janeiro: Guanabara II, 1982.

ALMEIDA JR., A. F. \& COSTA JR., J. B. O. L. Lições de medicina legal. 20 ed. São Paulo: Nacional, 1991.

BANDEIRA, Lourdes. "Três décadas de resistência feminista contra o sexismo e a violência feminina no Brasil: 1976 a 2006". Sociedade e Estado. V. 24, n. 2. Brasília: UnB, agosto de 2009.

BARROSO, Luis Roberto e BARCELOS, Ana Paula de. "O começo da história: a nova interpretação constitucional e o papel dos princípios no direito brasileiro". Revista Interesse Público. no 19, v. 5, 2003.

BASTOS, A. F. et. al. Medicina legal para não legistas, Campinas: Copola Edit., 1998.

BONAVIDES, Paulo. Ciência Política. Rio de Janeiro: Forense, 1993.

BOURDIEU, Pierre. A dominação masculina. Rio de Janeiro: Bertrand Brasil, 2003. 
BRASIL. Constituição da República Federativa do Brasil. Diário Oficial da União, Brasília, DF, 5.8.1988.

- Decreto $\mathbf{n}^{\circ}$ 847, de 11 de outubro de 1890. Disponível em: $<$ http://www6.senado.gov.br/legislacao/ListaPublicacoes.action?id=66049>. Acesso em 16.06.2011.

Lei 10.455, de 13 de maio de 2002. Disponível em: $<$ http://www.planalto.gov.br/ccivil/LEIS/2002/L10455.htm>. Acesso em 21.06.2011.

Lei 10.683, de 28 de maio de 2003. Disponível em: $<$ http://www.planalto.gov.br/ccivil_03/LEIS/2003/L10.683.htm>. Acesso em 10.07.2011.

. Lei 10.778, de 24 de novembro de 2003. Disponível em: $<$ http://www.planalto.gov.br/ccivil/LEIS/2003/L10.778.htm>

Lei 10.886, de 17 de junho de 2004. Disponível em: $<$ http://www.planalto.gov.br/ccivil_03/_Ato2004-2006/2004/Lei/L10.886.htm>. Acesso em: 21.06.2011.

. Lei 11.340, de 07 de agosto de 2006. Disponivel em: $<$ http://www.planalto.gov.br/ccivil/_Ato2004-2006/2006/Lei/L113406.htm>. Acesso em 26.05.2011.

. Lei Imperial de 16 de dezembro de 1830. Disponível em: $<$ http://www.planalto.gov.br/ccivil_03/Leis/LIM/LIM-16-12-1830.htm>. Acesso em 16.06.2011.

CAMPOS, Carmen Hein de. "O direito a uma vida sem violência”. In: LIMA, Fausto Rodrigues de; SANTOS, Claudiene (Coords.). Violência doméstica: vulnerabilidade e desafios na intervenção criminal e multidisciplinar. Rio de Janeiro: Lúmen Juris, 2009, p. 23. 
CEBALLOS, Elena. La violencia domestica - análisis sociológico, dogmático y de derecho comparado. Granada: Comares, 2001.

COHEN, Claudio. "Sexologia". In CARVALHO, Hilário Veiga et al. Compêndio de Medicina Legal. $2^{a}$ ed.. São Paulo: Saraiva, 1992.

CORTÊS, Iáris Ramalho. "Processo de Criação da Nova Lei sobre Violência Doméstica e Familiar contra a Mulher”. Protegendo as Mulheres da Violência Doméstica: Seminário de Capacitação para juízes, procuradores, promotores, advogados e delegados no Brasil. $3^{\mathrm{a}}$. Ed., Brasília: Secretaria Especial de Políticas para as Mulheres, 2006. Disponível em: <http://www.turminha.mpf.gov.br/para-oprofessor/publicacoes/cartilha-violencia-domestica.pdf $>$. Acesso em 19.06.2011.

CROCE, Delton e CROCE JR., Delton. Manual de medicina legal. São Paulo: Saraiva, 1994.

CUNHA, Rogério Sanches e PINTO, Ronaldo Batista. Violência Doméstica: Lei Maria da Penha (Lei 11.340/2006) comentada artigo por artigo. $3^{\text {a }}$ ed., São Paulo: RT, 2011.

D’OLIVEIRA, Ana Paula Pires Lucas. Violência de gênero, necessidades de saúde e uso de serviços em atenção primária. Tese de doutorado. Faculdade de Medicina da USP, 2000.

DEL-CAMPO, Eduardo Roberto Alcântara. Exame e levantamento técnico pericial de locais de interesse à justiça criminal: abordagem descritiva e crítica. Dissertação de mestrado. Faculdade de Direito da USP, 2008.

DIAS, Maria Berenice. A Lei Maria da Penha na Justiça: a efetividade da Lei 11.340/2006 de combate à violência doméstica e familiar contra a mulher. $2^{\mathrm{a}}$. ed., São Paulo: RT, 2010. 
DISTRITO FEDERAL. Secretaria de Estado da Mulher. Disponível em: $<$ http://www.mulher.df.gov.br/>. Acesso e, 02.01.2012.

D'OLIVEIRA, Ana Paula Pires Lucas et al. "Fatores associados à violência por parceiro íntimo em mulheres brasileiras”. Revista de Saúde Pública, São Paulo, v. 43, n. 2, abril 2009.

DOTTI, René Ariel. Curso de direito penal: parte geral. 2 ed. Rio de Janeiro: Forense, 2005.

FÁVERO, Flamínio. Medicina Legal. $1^{\text {o }}$ vol., $4^{\mathrm{a}}$ Ed.. São Paulo: Martins Editora, 1951.

FELIPE, Sônia T. e PHILIPHI, Jeanine Nicolazzi. A Violência das Mortes por Decreto - Um ensaio sobre Direito e Psicanálise a Três Estudos de Filmes à luz do Contratualismo. Florianópolis: Gráfica UFSC, 1996.

FRAGA, Paulo Antônio Ribeiro. As lesões corporais e o Código Penal. Rio de Janeiro: Freitas Bastos, 1959, p. 29.

FRANÇA, G. V. de. Medicina legal, 5 ed. Rio de Janeiro: Guanabara Koogan SA, 1998.

GELLES, Richard J.. Intimate violence in families, $3^{\text {a }}$ ed. Londres: Sage, 1997

GIORDANI, Mário Curtis. História de Roma - Antiguidade Clássica II. $15^{\mathrm{a}}$ edição. Petrópolis: Editora Vozes, 2002.

GIRARD, René. A violência e o sagrado, $2^{a}$ ed. São Paulo: Paz e Terra, 1999.

GOIÁS. Secretaria de Estado de Políticas para Mulheres e Promoção da Igualdade Racial. Disponível em: <http://www.semira.go.gov.br/>. Acesso em 02.10.2012. 
GOMES, Luiz Flávio e BIANCHINI, Alice. “Aspectos criminais da Lei de Violência contra a Mulher". Jus Navigandi, Teresina, ano 11, n. 1169, 13 set. 2006. Disponível em: <http://jus.com.br/revista/texto/8916>. Acesso em: 02.01.2012.

HERMANN, Leda Maria. Maria da Penha - Lei com nome de Mulher. São Paulo: Editora Servanda, 2007.

HOBBES, Thomas. O Leviatã. São Paulo: Martins Fontes, 1992.

HOBSBAWM, Eric. A era das revoluções: Europa 1789 - 1848. $15^{\mathrm{a}}$ ed.Rio de Janeiro : Paz e Terra, 2001.

INSTITUTO BRASILEIRO DE GEOGRAFIA E ESTATÍSTICA. População nos Censos Demográficos, segundo as Grandes Regiões e as Unidades da Federação - 1872/2010. Disponível em: $<$ http://www.ibge.gov.br/home/estatistica/populacao/censo2010/tabelas_pdf/Brasil_t ab_1_4.pdf>. Acesso em 18.06.2011.

JESUS, Damásio Evangelista de. Violência contra a mulher: aspectos criminais da Lei $\mathbf{n}^{0}$ 11.340/06. São Paulo: Saraiva, 2010, p. 50-51.

LAFER, Celso. A reconstrução dos Direitos Humanos - um diálogo com o pensamento de Hannah Arendt. 1 ${ }^{a}$. ed., São Paulo: Companhia das Letras, 1998.

LARRAURI, Elena. "É neutro o Direito Penal?" Revista de Ciências Penais n ${ }^{\circ} 1$ p.8. Ed. SAFE, Porto Alegre, 2003.

LIMA, Fausto Rodrigues de; SANTOS, Claudiene (Coords.). Violência doméstica: vulnerabilidade e desafios na intervenção criminal e multidisciplinar. Rio de Janeiro: Lumen Juris, 2009.

MARANHÃO, Odon Ramos. Curso básico de medicina legal, 8 ed. São Paulo: Malheiros, 1996. 
Manual de sexologia médico-legal. São Paulo: RT, 1972.

MARANHÃO. Secretaria de Estado da Mulher. Disponível em: $<$ http://www.semu.ma.gov.br/>. Acesso em 02.01.2012.

MATTA, Roberto da et alii. Violência brasileira. As raízes da violência no Brasil: reflexões de um antropólogo social. São Paulo: Brasiliense, 1982.

MAZZUOLI, Valerio de Oliveira; BIANCHINI, Alice. "Lei de violência doméstica e familiar contra a mulher (Lei Maria da Penha): constitucionalidade e convencionalidade”. Revista Forense, Rio, v. 402, 2009.

MORRISON, A. R.; BIEHL, M. L. A família ameaçada: violência doméstica nas Américas. Rio de Janeiro: FGV, 2000.

MOURA, Leides Barroso Azevedo et al . "Violências contra mulheres por parceiro íntimo em área urbana economicamente vulnerável, Brasília, DF”. Revista de Saúde Pública, São Paulo, v. 43, n. 6, dez. 2009, p. 944-953.

ORGANIZAÇAO DOS ESTADOS AMERICANOS. Comissão Interamericana de Direitos Humanos. Convenção Interamericana para Prevenir, Punir e Erradicar a Violência Contra a Mulher: Convenção de Belém do Pará. Disponível em: <http://www.cidh.org/Básicos/base8.htm>. Acesso em 29.05.2011.

ORGANIZAÇÃO DOS ESTADOS AMERICANOS. Comissão Interamericana de Direitos Humanos. Relatório $n^{\circ}$ 54/01 - Caso 12.051 - Maria da Penha Maia $\begin{array}{lllll}\text { Fernandes } & \mathbf{x} & \text { Brasil. } & \text { Disponível }\end{array}$ $<$ http://www.cidh.oas.org/annualrep/2000port/12051.htm>. Acesso em 20.06.2011.

ORGANIZAÇÃO MUNDIAL DE SAÚDE. WHO multi-country study on women's health and domestic violence against women. Genebra, 2005. Disponível em: $<$ http://www.who.int/reproductivehealth/publications/violence/9241593512/en/in dex.html> (em inglês). Acesso em 10.12.2011. 
. World Report on Violence and Health. Genebra, 2002. Disponível em: $<$ http://whqlibdoc.who.int/hq/2002/9241545615.pdf $>$ (em inglês). Acesso em 10.12.2011.

PAGELOW, Mildred D.; PAGELOW, Lloyd W.. Family violence. Nova York: Greenwood, 1984.

PARAÍBA. Secretaria de Estado da Mulher e da Diversidade Humana. Disponível em: <http://www.paraiba.pb.gov.br/mulher-e-da-diversidade-humana>. Acesso em 02.01.2012.

PENNA, João Bosco. Lesões Corporais: Caracterização Clínica e Médico-Legal. Leme: Editora de Direito, 1996.

PERNAMBUCO. Secretaria de Estado da Mulher. Disponível em: $<$ http://www2.secmulher.pe.gov.br/web/secretaria-da-mulher $>$. Acesso em 02.01.2012.

PIMENTEL, Silvia. PANDJIARJIAN,Valéria. Percepções das Mulheres em relação ao Direito e a Justiça, Legislação, Acesso e Funcionamento. Porto Alegre: SAFE, 2001.

PIOVESAN, Flávia. Direitos Humanos e o Direito Constitucional Internacional. São Paulo: Max Limonad, 1996.

PORTO, Pedro Rui da Fontoura. Violência Doméstica Familiar Contra a Mulher. Porto Alegre: Livraria do Advogado, 2007.

PORTUGAL. Ordenações Filipinas. Título XXXVI do Livro V. Disponível em: $<$ http://www.ci.uc.pt/ihti/proj/filipinas/15p1187.htm>. Acesso em 14.06.2011.

PREFEITURA DA CIDADE DE SÃO PAULO. Histórico Demográfico do Município de São Paulo: Introdução. Disponível em: 
$<\mathrm{http}$ ://smdu.prefeitura.sp.gov.br/historico_demografico/introducao.php $>$. Acesso em 18.06.2011.

RIO GRANDE DO SUL. Secretaria de Políticas para as Mulheres do Rio Grande do Sul. Disponível em: <http://www.spm.rs.gov.br/>. Acesso em 02.01.2012.

SABADELL, Ana Lucia. "Perspectivas jussociológicas da violência doméstica: efetiva tutela de direitos fundamentais e/ou repressão penal". Revista dos Tribunais, São Paulo, v. 840, 2005.

SAFFIOTI, Heleieth. "Contribuições feministas para o estudo da violência de gênero". Cadernos Pagu, Campinas, n. 16, 2001.

SANTOS, William Douglas Resinente dos (Coord.). Medicina legal: teoria e prática à luz do direito penal e processual penal. 7.ed. Rio de Janeiro: Impetus, 2006.

SÃO PAUlO. Conselho Estadual da Condição Feminina. Disponível em: $<$ http://www.condicaofeminina.sp.gov.br/>. Acesso em 02.01.2012.

SARLET, Ingo Wolfgang. Dignidade da pessoa humana e direitos fundamentais na Constituição Federal de 1988. Porto Alegre: Livraria do Advogado, 2001.

SCHRAIBER, Lilia Blima et al. "Prevalência da violência contra a mulher por parceiro íntimo em regiões do Brasil”. Revista de Saúde Pública, São Paulo, v. 41, n. 5, 2007.

SCHRAIBER, Lilia Blima; D'OLIVEIRA, Ana Flávia P L; COUTO, Márcia Thereza. "Violência e saúde: estudos científicos recentes". Revista de Saúde Pública. São Paulo, v. 40, n. spe, 2006.

SILVA, José Afonso da. Curso de Direito Constitucional Positivo. 12 $2^{\text {a }}$ ed.. São Paulo: Malheiros, 1996. 
SOARES, Orlando. Sexologia forense, 1 ed. Rio de Janeiro: Freitas Bastos, 1990.

SOUZA, Sérgio Ricardo de. Comentários à Lei de Combate à Violência Contra a Mulher - Lei Maria da Penha 11.340/06. Curitiba: Juruá Editora, 2007.

STARK, Evan; FLITCRAFT, Anne. Women at risk - domestic violence and women's health. Londres: Sage, 1996.

STRATHERN, Marilyn. "Necessidade de pais, necessidade de mães". Estudos Feministas. V. 3, n. 2. Florianópolis: UFSC, 1995, p. 303-329.

SUPERIOR TRIBUNAL DE JUSTIÇA. HC 73.161/SC, Rel. Min. Convocada Jane Silva, DJ 17.09.2007, p.317.

SUPERIOR TRIBUNAL DE JUSTIÇA. HC 9.892-RJ, Rel. orig. Min. Hamilton Carvalhido, Rel. para ac. Min. Fontes de Alencar. DJ 26.3.01, p. 412.

SUTTER, Matilde Josefina. Determinação e mudança de sexo: aspectos médicolegais. São Paulo: RT, 1993.

TRIBUNAL DE JUSTIÇA DE MINAS GERAIS. HC 1.0000.09.513119-9/000. Rel. Des. Júlio Cezar Gutierrez, j. 24.02.2010.

TRIBUNAL DE JUSTIÇA DE SANTA CATARINA. CJ 2009.006461-6. 3." C.Crim., Rel. Des. Roberto Lucas Pacheco, j. 14.08.2009.

TUCCI, Rogerio Lauria. Do corpo de delito no direito processual penal brasileiro. São Paulo: Saraiva, 1978.

UNESCO. De Mãos Dadas com a Mulher: a UNESCO como agente promotor da igualdade entre gêneros. Brasília: UNESCO, 2002, p. 71. Disponível em $<$ http://unesdoc.unesco.org/images/0012/001271/127141por.pdf $>$. Acesso em 19.06.2011. 
VELHO, Gilberto et alii. Cidadania e violência. Rio de Janeiro: UFRJ/FGV, 1996.

VENTURI, G.; RECAMAN, M.; OLIVEIRA, S. A mulher brasileira no espaço público e privado. São Paulo: Fundação Perseu Abramo, 2001.

VERONESE, Josiane Rose Petry. Entre violentados e violentadores? São Paulo: Cidade Nova, 1998.

VIEIRA, Elisabeth Meloni; PERDONA, Gleici da Silva Castro; SANTOS, Manoel Antonio dos. "Fatores associados à violência física por parceiro íntimo em usuárias de serviços de saúde”. Revista de Saúde Pública, São Paulo, v. 45, n. 4, ago. 2011.

VIEIRA, Luiza Jane Eyre de Souza et al. "Fatores de risco para violência contra a mulher no contexto doméstico e coletivo". Saúde e sociedade. São Paulo, v. 17, n. 3, 2008 .

ZACHARIAS, M. \& ZACHARIAS, E. Dicionário de medicina legal. Curitiba: Educa, 1988.

ZAFFARONI, Eugenio Raúl; PIERANGELLI, José Henrique. Manual de direito penal brasileiro: parte geral. 4. ed. São Paulo: Editora Revista dos Tribunais, 2002.

ZARZUELA, José Lopes. Medicina legal para provas e concursos. São Paulo, Edit Angelotti Ltda., 1993. 